\title{
EFEITO DE DIFERENTES AGENTES ANTI-HIPERESTÉSICOS, COMERCIAL E EXPERIMENTAIS, SOBRE A PERMEABILIDADE DENTINÁRIA EM FUNÇÃO DO TEMPO PÓS-APLICAÇÃO
}

\author{
SÉRGIO LIMA SANTIAGO
}

Dissertação apresentada à Faculdade de Odontologia de Bauru, da Universidade de São Paulo, como parte dos requisitos para obtenção do título de Mestre em Odontologia, área de Dentística. 


\title{
EFEITO DE DIFERENTES AGENTES ANTI-HIPERESTÉSICOS, COMERCIAL E EXPERIMENTAIS, SOBRE A PERMEABILIDADE DENTINÁRIA EM FUNÇÃO DO TEMPO PÓS-APLICAÇÃO
}

\author{
SÉRGIO LIMA SANTIAGO
}

Dissertação apresentada à Faculdade de Odontologia de Bauru, da Universidade de São Paulo, como parte dos requisitos para obtenção do título de Mestre em Odontologia, área de Dentística.

(Edição Revista)

Orientador: Prof. Dr. José Carlos Pereira

BAURU 
Santiago, Sérgio Lima

Sa59e Efeito de diferentes agentes anti-hiperestésicos, comercial e experimentais, sobre a permeabilidade dentinária em função do tempo pós-aplicação / Sérgio Lima Santiago - - Bauru,1999.

137p. : il. ; $29,7 \mathrm{~cm}$.

Dissertação (Mestrado) - - Faculdade de Odontologia de Bauru, USP.

Orientador: Prof. Dr. José Carlos Pereira.

Autorizo, exclusivamente para fins acadêmicos e científicos, a reprodução total ou parcial desta Dissertação, por processos fotocopiadores e/ou meios eletrônicos.

Assinatura do autor:

Data: 1ํ de Julho de 1999. 


\section{SÉRGIO LIMA SANTIAGO}

01 de Maio de 1969

Fortaleza - CE

Filiação

1987-1991

1994

1994

1996

1996

1997-1999

Associações de classe
Nascimento

Danilo de Alencar Santiago e

Maria Alba Lima Santiago

Curso de Graduação em Odontologia na Universidade Federal do Ceará - UFC.

Professor Substituto das Disciplinas de Dentística Restauradora Laboratorial e Dentística Operatória Clínica I, do Departamento de Odontologia Restauradora da Universidade Federal do Ceará - UFC

Professor Auxiliar da Disciplina de Dentística Operatória Clínica I do Departamento de Odontologia Restauradora da Universidade Federal do Ceará - UFC

Vice-Chefe da Clínica Integrada do Curso de Odontologia da UFC

Secretário do Centro de Estudos dos Docentes do Curso de Odontologia da UFC.

Curso de Pós-Graduação em Dentística, a nível de Mestrado na Faculdade de Odontologia de Bauru da Universidade de São Paulo - USP

Associação Brasileira de Odontologia - ABO secção Ceará

Sindicato dos Odontologistas no Estado do Ceará.

Associação dos Docentes da Universidade Federal do Ceará.

Centro de Estudos dos Docentes do Curso de Odontologia da UFC

Grupo Brasileiro dos Professores de Dentística Associação dos Pós-Graduandos da FOB USP.

Sociedade Brasileira de Pesquisa Odontológica.

International Associaton for Dental Research. 
"SENHOR, vós me perscrutais e conheceis, sabeis tudo de mim, observais todos os meus passos. A palavra ainda não me chegou à língua e já a conheces toda. Cada uma de minhas ações vossos olhos viram. Conduzeme pelo caminho que leva à Eternidade." Graças PAl! Graças.

Aos meus pais, Danilo e Alba, tudo o que sou e tenho devo a vocês. Obrigado pela presença e apoio em todas as etapas de minha vida. Vocês são heróis por formar e educar uma Grande Família. Amo vocês!

Aos meus irmãos, Haroldo, Regina, Fátima, Rubens (in memorian), Gláucia, Helder, Eliane, Maria Luiza, Catarina, Vera, Fernanda e juntamente com cunhados e sobrinhos. Vocês são muito especias! Nossa amizade e carinho nos dão forças para superar todas as adversidades. 


\section{AGRADECIMENTOS ESPECIAIS}

Heloísa Helena Cunha Marques, Tutora do PET, Professora, Colega de Trabalho e principalmente amiga. Seus ensinamentos de vida e profissão foram úteis a minha formação. Obrigado pelo apoio em todos os momentos.

Haroldo César Pinheiro Beltrão, seu amor ao Ensino e à Instituição estiveram sempre presentes e me foram exemplos na carreira Universitária.

José Carlos Pereira, pelo exemplo de amor e dedicação à Universidade e pela orientação do trabalho.

Ricardo Marins de Carvalho, Professor, Orientador e acima de tudo um grande amigo. A convivência com você, juntamente com sua esposa, Andréa, foi muito valorosa. Obrigado pelos ensinamentos e pelo acolhimento! 


\section{AGRADECIMENTOS}

- Aos professores do Departamento de Dentística pelos conhecimentos transmitidos.

- Ao Professor Paulo Francisconi pela confiança e amizade.

- Aos Funcionários do Departamento de Dentística: Nelson, Rosinha, Rosa e Eloisa

- Aos Funcionários do Departamento de Materiais Dentários: Alcides, Lourisvalda e Sandrinha.

- Aos Funcionários da Pós-Graduação: Ana, Cleusa, Débora e Heloísa.

- Aos amigos do Curso de Mestrado: Rodrigo, Monica, Juliana, Juliano e Ana Christina. Nossa amizade, pautada pelo respeito, compreensão e cumplicidade foi muito proveitosa. Torço pela felicidade pessoal e concretização das aspirações profissionais de todos vocês.

- Aos colegas da turma de Mestrado: Margareth, Luiza, Lussara, Lúcia, Rosana, Roberta e Marcelo.

- Aos demais colegas de outros cursos de Pós-Graduação. 
- Aos grandes amigos: Cláudio, Luciano, Nelsinho, Christian, Cristiane, Maria Carmem, Raquel Terada, Sal e Sérgio Joaquim.

- Aos amigos que me ajudaram no início da vida acadêmica: Jeová Neto, Nonato Soares de Castro, Eduardo Vargas e Dayse Amaral.

- Aos amigos de todas as horas: Osvaldo Filho, Paulo Beltrão, Régis Cavalcante e Trycia Carneiro.

- Aos meus ex-alunos do Curso de Odontologia da Universidade Federal do Ceará.

- Aos amigos da Disciplina de Dentística da UFC: Heloísa, Haroldo, Emanuel, Vicente, Carlos Augusto e Lidiany.

- Aos funcionários do Departamento de Odontologia Restauradora da UFC: Marta, Germano e Lucimar.

- À Universidade Federal do Ceará e à CAPES pelo apoio financeiro para o desenvolvimento e realização do Curso de Pós-Graduação. 


\section{SUMÁRIO}

LISTA DE ABREVIATURAS E SÍMBOLOS ............................................. ix

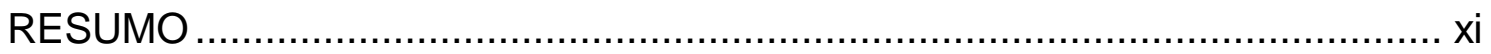

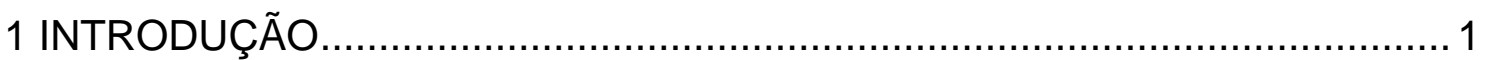

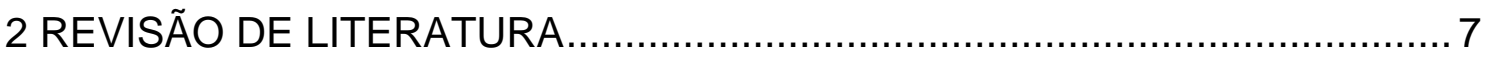

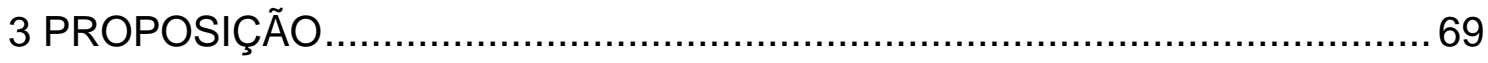

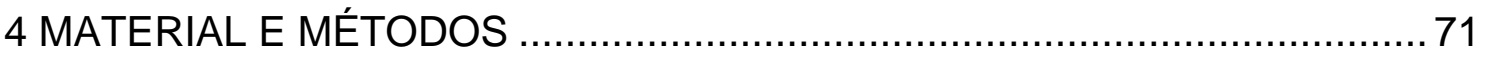

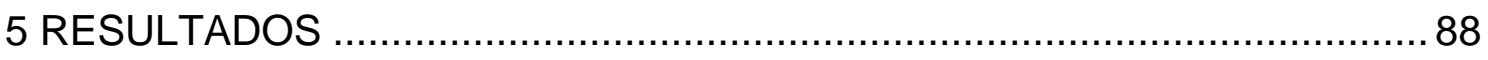

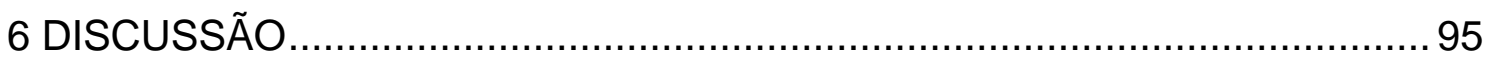

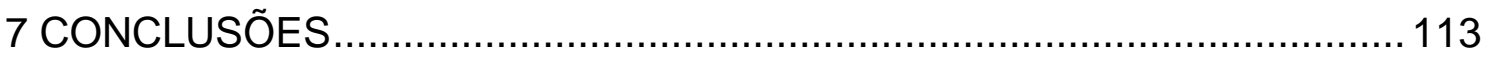

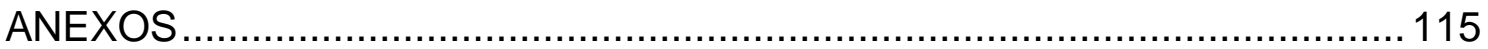

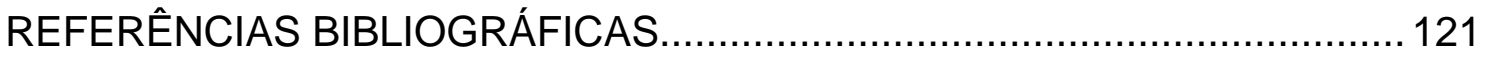

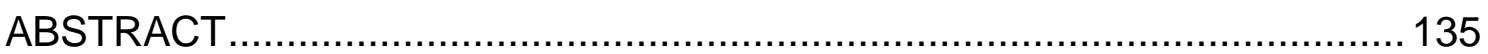




\title{
LISTA DE ABREVIATURAS E SÍMBOLOS
}

\author{
$\mathrm{mm}: \quad$ Milímetro \\ $\mathrm{mM} \quad$ Milimolar \\ $\mathrm{mm}^{2} \quad$ Milímetro ao quadrado \\ $\mathrm{mmHg} \quad$ Milímetro de mercúrio \\ rpm: Rotações por minuto \\ X: $\quad$ Indica aumento em número de vezes.(Ex.:30X) \\ $\mathrm{cmH}_{2} \mathrm{O}$ : Centímetro de água (unidade de pressão) \\ $\mathrm{ml}$ : Mililitro \\ $\mathrm{cm}^{2}$ : $\quad$ Centímetro ao quadrado \\ $\mu \mathrm{l}: \quad$ Microlitro \\ $\mu \mathrm{m} \quad$ Micrômetro \\ EDTA: Ácido etileno diamino tetra-acético \\ $\mu \mathrm{l} / \mathrm{min}: \quad$ Microlitro por minuto \\ $\mathrm{cm} / \mathrm{min}$. Centímetro por minuto \\ $\min$ Minuto \\ S Segundo \\ \%: $\quad$ Porcentagem \\ $\mathrm{pH}: \quad$ Potencial hidrogeniônico \\ DD-1: $\quad$ Dessensibilizador Dentinário 1 \\ DD-2: $\quad$ Dessensibilizador Dentinário 2 \\ M: $\quad$ Molar \\ Lp: $\quad$ Condutividade hidráulica \\ Q: $\quad$ Filtração \\ P: $\quad$ Pressão \\ AS: $\quad$ Área de superfície \\ $\mu$ l. $\mathrm{cm}^{-2} \cdot \min ^{-1} \cdot \mathrm{cmH}_{2} \mathrm{O}^{-1}$ :Microlitro centímetro quadrado elevado a
}


menos 2 minuto elevado a menos 1 centímetro de água elevado a menos 1

$\begin{array}{ll}\mathrm{x}: & \text { Representativo à distância percorrida } \\ \mathrm{y}: & \text { Representativo a tempo decorrido } \\ \mathrm{p}: & \text { Significância estatística } \\ <: & \text { Menor que (para significância estatística) } \\ \pm: & \text { Mais ou menos } \\ \mathrm{X}: & \text { Média aritmética } \\ 5^{\prime}: & \text { Cinco minutos } \\ 15^{\prime}: & \text { Quinze minutos } \\ 30^{\prime}: & \text { Trinta minutos }\end{array}$




\section{RESUMO}

Verificou-se, in vitro, a influência do tempo pós-aplicação de agentes anti-hiperestésicos comercial e experimentais na permeabilidade dentinária através da medição da condutividade hidráulica, utilizando-se o método de discos de dentina. Cinquenta discos de dentina obtidos a partir de terceiros molares humanos recém extraídos foram divididos em 5 grupos de 10 dentes. No grupo I utilizou-se o OXA-GEL, no grupo II o agente experimental DD-1, no grupo III o agente experimental DD-2, no grupo IV, um agente placebo e no grupo V, água deionizada. Para todos os grupos estudados foram determinadas a mínima e máxima permeabilidade dos espécimes pela simulação da smear layer e condicionamento ácido respectivamente. Após a determinação desses parâmetros aplicou-se os agentes e mediu-se a condutividade hidráulica da dentina nos tempos imediato, 5, 15, e 30 minutos após a aplicação. O último procedimento consistiu na verificação da efetividade dos agentes utilizados submetendo-se os espécimes a um meio ácido. Com base na análise estatística dos resultados concluiu-se que a permeabilidade dentinária reduziu com o passar do tempo para todos os grupos. Os grupos I, II e III (OXA-GEL, DD-1 e DD-2) não apresentaram diferenças estatísticas significantes entre si, em todas as condições testadas, o mesmo ocorrendo entre os grupos IV e V (PLACEBO e ÁGUA DEIONIZADA). Entretanto, foram detectadas diferenças estatisticamente significantes entre os agentes OXA-GEL, DD-1 e DD-2 e o agente PLACEBO e ÁGUA DEIONIZADA. No que diz respeito ao desafio ácido, os grupos I, II e III mostraram-se ácido resistente, mantendo os valores de permeabilidade 
reduzidos, enquanto que os grupos IV e $\mathrm{V}$ foram sensíveis ao desafio ácido, aumentando os valores de permeabilidade. A redução dos valores de permeabilidade em função do tempo apresentada pelo grupo $\mathrm{V}$, o qual não foi empregado agente anti-hiperestésico, faz com que a interpretação dos resultados dos demais grupos, leve em consideração um arrefecimento natural da permeabilidade com o passar do tempo, proporcionado pelo dispositivo utilizado para a medição da condutividade hidráulica da dentina. 


\section{INTRODUÇÃo}

A dentina é um tecido conjuntivo mineralizado, avascular ${ }^{31} \mathrm{e}$ inervado $^{41}$, que apresenta a seguinte composição: $70 \%$ de material inorgânico, 18\% de material orgânico e 12\% de água. Esta composição é variável de acordo com a idade do dente, devido a mineralização normal e progressiva que ocorre após a completa formação do órgão dentário ${ }^{31}$.

A característica mais importante da dentina é a presença de túbulos dentinários os quais se estendem perifericamente desde a junção odontoblasto pré-dentina por toda a espessura desse tecido ${ }^{78}$. A permeabilidade dentinária é uma consequência direta da presença de túbulos. A densidade de túbulos dentinários varia de 45.000 a $65.000 / \mathrm{mm}^{2}$ na região próxima a polpa, 29.500 a $35.000 / \mathrm{mm}^{2}$ na região mediana e de 15.000 a $20.000 / \mathrm{mm}^{2}$ próximo ao limite amelodentinário. Essa aparente diminuição no número de túbulos está relacionada com o aumento da área de superfície de dentina em direção à junção amelodentinária. O diâmetro dos túbulos na região pulpar é de 2 a $3 \mu \mathrm{m}$, e próximo ao limite amelodentinário é de 0,5 a $0,9 \mu \mathrm{m}^{14}$. O túbulo dentinário é composto por: dentina peritubular, processo odontoblástico, colágeno, nervos e fluido dentinário. Estes componentes de alguma maneira influenciam na permeabilidade dentinária ${ }^{78}$.

Dentina e polpa não apenas estão próximas topograficamente mas, também, há entre esses tecidos uma íntima relação sob os aspectos funcionais e de desenvolvimento, razões importantes para considerá-los como uma entidade ou órgão ${ }^{31}$. 
Em condições normais, a dentina encontra-se recoberta pelo esmalte na região correspondente à coroa dentária e pelo cemento na porção radicular dos dentes .Esses elementos naturais de proteção, diferentemente da dentina, não apresentam sensibilidade aos estímulos próprios da cavidade bucal ${ }^{67}$.

A dentina é mais resiliente do que o esmalte, e sua estrutura tubular absorve o impacto das forças transmitidas através do esmalte e o distribui por todas as estruturas de suporte do dente. Os fluidos contidos nos túbulos dentinários são importantes na transferência hidráulica e no alívio de estresses ${ }^{41}$. Quando, de alguma forma, esmalte e cemento são desgastados, a estrutura tubular e sensível de dentina, passa a ser uma via de fácil transporte de substâncias da cavidade bucal para a polpa ${ }^{41,67}$ e vice-versa. A hiperestesia dentinária está associada com a exposição de dentina à cavidade bucal ${ }^{2}$, e é caracterizada por uma dor aguda, bem localizada e transitória, em resposta a estímulos táteis, térmicos, evaporativos e osmóticos ${ }^{44}$.

A hiperestesia dentinária afeta 10 a $20 \%$ da população, podendo acometer qualquer dente, sendo um consenso da maioria dos estudos ser mais comum em caninos e primeiros pré-molares e quase que exclusivamente na face vestibular. A ocorrência em outras superfícies do dente, tais como cúspides, bordas incisais e face palatina ou lingual é menos freqüente. Entretanto nem toda superfície dentinária exposta apresenta sensibilidade, e a região sensível pode variar em extensão e em sensibilidade a diferentes estímulos ${ }^{35}$.

A teoria hidrodinâmica da dentina sensível, desenvolvida pela combinação de experimentos laboratoriais e clínicos, advoga que uma grande variedade de estímulos induzem a movimentação do fluido ao longo da dentina, e 
que esta movimentação excita os nervos mecanorreceptores próximos à polpa, causando dor. Esta teoria defende que o bloqueio dos túbulos dentinários interfere na movimentação do fluido ao longo da dentina e diminui a excitabilidade dos nervos, reduzindo a hiperestesia dentinária ${ }^{44}$.

Por sua íntima relação com a polpa, a dentina é naturalmente sensível, e como já foi dito, para que essa sensibilidade se manifeste clinicamente, é necessário sua exposição à cavidade bucal. A maneira pela qual a dentina é exposta influencia sua sensibilidade. Dentina recém-cortada por instrumentos operatórios e exposta por procedimentos de raspagem periodontal pode não ser sensível devido à presença de smear-layer. Já na hiperestesia dentinária, geralmente não há smear-layer e os túbulos encontram-se expostos. 0 aumento da formação de dentina peritubular e a deposição de dentina terciária reduzem a permeabilidade ${ }^{35}$.

Se a dentina não for permeável, é improvável que seja muito sensível. Sob condições patológicas, a dentina torna-se menos permeável, através da formação de dentina reparadora, que apresenta uma menor quantidade de túbulos e consequentemente menor quantidade de nervos que a dentina primária ${ }^{42}$.

Há dois mecanismos responsáveis pela passagem de substâncias pela dentina: a difusão e a filtração. A difusão é um processo pelo qual o transporte de substâncias é feito de uma área de alta concentração para uma área de baixa concentração. Na difusão não há movimentação do fluido, mas somente deslocamento molecular. Na filtração, a movimentação do fluido ocorre de uma área de maior pressão hidrostática para uma área de menor pressão ${ }^{42}$. 
De acordo com a teoria hidrodinâmica da dentina sensível, o movimento do fluido é o responsável pela transferência de uma série de estímulos (tátil, osmótico, térmico e evaporativo) em ativação elétrica do nervo. O aumento da sensibilidade da dentina pode ser devido ao aumento da proporção do movimento do fluido dentinário ou a um aumento na excitabilidade do nervo, ou de ambos ${ }^{42,45}$. Este tipo de movimento pode ser quantificado pela medição da condutividade hidráulica da dentina ${ }^{42}$. A condutividade hidráulica de um tecido expressa a facilidade com que o fluido pode mover-se através de uma superfície, sob uma pressão, em um espaço de tempo ${ }^{45}$. A condutividade hidráulica da dentina é dependente de uma série de variáveis, tais como: comprimento dos túbulos, o número de túbulos por unidade superficial de área, a pressão aplicada, a viscosidade do fluido e o raio do túbulo elevado à quarta potência ${ }^{42,45}$. Esta variável pode ser modificada pela presença de smear layer e smear plugs, que regularão a condutividade hidráulica, e consequentemente a presença da hiperestesia ${ }^{42}$.

A importância de métodos laboratoriais na medição da permeabilidade dentinária é de grande valia ${ }^{73}$, uma vez que a hiperestesia é um fenômeno sensorial complexo, dependente de fatores fisiológicos e emocionais não completamente definidos ${ }^{67}$.

Os agentes e as terapias anti-hiperestésicas mais comumente empregados são aqueles que interagem com a condutividade hidráulica da dentina, que pode ocorrer através da precipitação de proteínas que compõem o processo de Tomes, pela formação e deposição de cristais na embocadura e interior dos túbulos dentinários, pelo recobrimento da dentina e/ou impregnação dos túbulos e, finalmente, através de procedimentos restauradores de modo geral ${ }^{67}$. Os agentes 
à base de oxalato de potássio atuam, então, por obliteração dos túbulos através da formação e deposição de cristais de oxalato de cálcio em presença de meio ácido. Esses cristais reduzem a movimentação de fluidos através da dentina e consequentemente reduzem a hiperestesia dentinária.

O presente trabalho tem por objetivo avaliar o potencial de redução da permeabilidade dentinária em função do tempo pós-aplicação, de agentes anti-hiperestásicos à base de oxalato de potássio. 


\section{REVISÃO DE LITERATURA}

A hiperestesia dentinária é uma resposta exagerada a estímulos sensoriais relacionada à exposição da dentina ao meio bucal ${ }^{3}$. Essa exposição pode ser resultante de perda de esmalte por processos de erosão, atrição abrasão e abfração, ou por desnudamento da superfície radicular por recessão gengival ou tratamento periodontal.

A literatura é vasta a respeito do assunto em estudo, uma vez que, são inúmeros os agentes e as terapias preconizadas para o tratamento da hiperestesia dentinária, o que denota, em princípio, que nenhum deles é completamente eficaz para tal finalidade ${ }^{67}$. A teoria hidrodinâmica da dentina sensível afirma que a movimentação do fluido dentinário no interior dos túbulos, induzidas por estímulos na superfície dentinária, é responsável pela ativação indireta dos nervos mecanorreceptores próximos à polpa e o surgimento da sensação dolorosa ${ }^{40}$.

Historicamente, vários agentes anti-hiperestésicos têm sido aplicados para a redução ou total eliminação da dor, dentre eles, óleo quente, arsênico, nitrato de prata e formaldeído. Atualmente, surgiram outras formas de tratamento para a hiperestesia dentinária, que consistem na aplicação de agentes para a obstrução dos túbulos dentinários que interagem com a condutividade hidráulica da dentina, permitindo o alívio e eliminação da sensação dolorosa. Dentre esses agentes, a aplicação tópica de soluções à base de oxalato de potássio tem demonstrado excelentes resultados na redução da permeabilidade dentinária, através da formação de cristais de oxalato de cálcio que ocluem os túbulos 
dentinários abertos ${ }^{19}$. Desta forma, como o presente trabalho é referente aos agentes utilizados no tratamento da hiperestesia dentinária, procurou-se ater aos trabalhos laboratoriais com a utilização do oxalato de potássio através da medição da condutividade hidráulica de discos de dentina. Entretanto, para um melhor embasamento, foram também revistos trabalhos clínicos e trabalhos com outros métodos de se quantificar a permeabilidade dentinária.

STEVENSON ${ }^{76}$, em 1965, apresentou uma tentativa de primeiramente observar microscopicamente a movimentação do fluido de dentina exposta como resultado de uma redução da pressão aplicada in vitro, e uma possível correlação entre esta movimentação e a aspiração de odontoblastos. Uma câmara foi desenhada permitindo que uma área exposta da coroa fosse observada microscopicamente, enquanto esta superfície era sujeita a reduções de pressão. Os dentes utilizados foram pré-molares, extraídos por razões ortodônticas, de pacientes com 10 a 13 anos e molares inclusos de pacientes com 17 a 28 anos. Imediatamente após a extração os dentes foram colocados numa solução salina fisiológica e usados no período de 2 a 3 horas. A dentina foi exposta por fratura ou por corte com disco de carborundum.

O fluido na forma de pequena quantidade de líquido passando pelos túbulos e formando um exsudato com a redução da pressão era visto quando a dentina era exposta por fratura. A dentina exposta por corte teve sua esxudação reduzida marcadamente tanto em quantidade como em proporção. A aspiração de odontoblastos na dentina exposta por fratura às vezes parecia estar relacionada com o movimento do fluido para fora dos túbulos, mas não ocorreu caso 
algum em que o fluido tenha saído em grande quantidade e rapidamente. A aspiração de odontoblastos por redução de pressão não ocorreu em dentinas expostas por corte ou desgaste.

POLHAGEN; BRÄNNSTRÖM ${ }^{68}$, em 1971, prepararam cavidades nas faces vestibulares e linguais de dez pré-molares humanos com alta velocidade e refrigeradas por ar para ressecar as cavidades. Uma cavidade de cada dente foi escolhida para remoção superficial da camada ressecada seguida por reidratação. Metade da raiz do dente foi cortada e o espécime foi conectado a um capilar de vidro milimetrado e repleto de solução salina. Éter, solução de cloreto de cálcio e jatos de ar foram aplicados nas cavidades de cada dente. A movimentação do líquido no capilar foi registrada para cada teste e foi mais pronunciada nas cavidades reidratadas.

Sabe-se que os agentes testados quando aplicados à dentina podem produzir dor, mas a sensibilidade é bastante reduzida depois do ressecamento. Os resultados indicam que uma razão para a redução de sensibilidade deve ser o bloqueio dos túbulos da parede cavitária, reduzindo a movimentação do conteúdo tubular para o exterior. Esta movimentação para fora, é o estímulo usual para produção de sensibilidade.

BRÄNNSTRÖM; ASTRÖM ${ }^{5}$, em 1972, afirmaram que experimentos in vivo e in vitro em dentes humanos tem dado suporte à hipótese de que a hidrodinâmica é responsável pela transmissão do estímulo da dor da superfície dentinária para as terminações nervosas no complexo dentino-pulpar e/ou 
polpa. Os autores concluíram que o movimento do conteúdo tubular da polpa para o exterior é o principal responsável pelo aparecimento da dor, mais do que o deslocamento na direção oposta. A diferença da resposta hidrodinâmica ao frio, ar e calor parece corresponder a diferenças observadas clinicamente na qualidade da dor, concluindo que há dois tipos de dor nos dentes, possivelmente mediadas por dois tipos de nervos.

\section{JOHNSON; OLGART; BRÄNNSTRÖM ${ }^{22}$, em 1973,} examinaram e mediram por métodos diretos a movimentação (para fora) dos fluidos dos túbulos dentinários em dentinas expostas por fraturas com gradiente de pressão fisiológica, e verificaram se tal movimentação pode produzir aspiração de odontoblasto. $\mathrm{O}$ experimento foi in vitro, mas todas as condições fisiológicas foram representadas da melhor maneira possível. Nos dentes em que a superfície dentinária foi obtida por fratura houve uma movimentação do fluido para fora dos túbulos, mas nenhum tipo de movimentação foi observada nos dentes em que a superfície de dentina foi desgastada. Na região central da superfície dentinária exposta por fratura, os túbulos apresentavam-se fraturados, enquanto que na periferia, correspondente a um quarto e a um terço da superfície dentinária exposta, os túbulos estavam desgastados. Na dentina fraturada, com túbulos visivelmente abertos, a média de movimentação foi superior a $0,6 \mu \mathrm{l} / \mathrm{mm}^{2} . \mathrm{d}$; isto implica que um túbulo aberto pode esgotar seu conteúdo líquido cerca de dez vezes ao dia.

O exame histológico dos dentes sugere que a redução na camada de odontoblasto por aspiração é um resultado da movimentação para fora do fluido produzido por um gradiente de pressão fisiológica. 
BRÄNNSTRÖM; JOHNSON ${ }^{6}$, em 1974, examinaram a superfície dentinária exposta por desgaste, através de microscopia eletrônica de varredura, após o tratamento com vários agentes de limpeza. O efeito dos diferentes tipos de soluções desmineralizantes foi também testado. Os agentes desmineralizantes produzem uma superfície limpa, desobstruem e ampliam a abertura dos túbulos dentinários, que estavam obliterados por smear layer, após o preparo. Isto foi considerado um efeito indesejável, pois os smears plugs previnem o crescimento de bactérias no interior dos túbulos. Das soluções testadas, uma solução microbicida com flúor obteve o melhor resultado, com bom efeito de limpeza sem abrir ou alargar demais os túbulos dentinários.

OUTHWAITE; MCKENZIE; PASHLEY ${ }^{37}$, em 1974, desenvolveram um dispositivo para facilitar o estudo da permeabilidade dentinária, o qual consiste de uma câmara com sua parte superior aberta, em contato com o meio ambiente (split-chamber). A câmara apresenta uma porção superior e uma inferior que são adaptadas por rosqueamento e recebe a estrutura dentária, na forma de segmento de coroa, para a realização dos experimentos. Neste dispositivo, o volume do reservatório superior e o selamento da superfície dentária é determinado pelo diâmetro e profundidade do orifício da porção superior da câmara e pelo diâmetro dos anéis de borracha. Depois de posicionar o segmento de coroa na câmara, o dispositivo é posicionado sobre um coletor de fração. Uma solução contendo isótopo radioativo é adicionada no reservatório superior, enquanto a parte inferior da câmara, que é contígua à câmara pulpar é continuamente lavada por uma corrente de solução numa proporção constante de pressão. A proporção que o isótopo 
traçador difunde-se pela dentina é quantificada pelo cálculo da radioatividade de cada tubo de teste coletor.

Muitas variações no formato da câmara têm sido utilizadas para aplicações específicas. Por exemplo, a metade inferior da split-chamber tem sido modificada pela colocação de tubos de entrada e saída e pelo selamento das porções superior e inferior com anéis de borracha. Outra variação foi usar a câmara com suas metades superior e inferior vedadas com tubos de entrada e saída. Este desenho permitiu uma contínua perfusão em ambos os lados da dentina, que é útil quando se mede fluxo bidirecional de isótopos.

\section{OUTHWAITE; LIVINGSTON; PASHLEY ${ }^{36}$, em 1976,} estudaram as modificações da permeabilidade dentinária, levando em consideração mudanças na área de superfície, espessura dos discos, temperatura e tempo após a extração. Os autores fazem um paralelo entre o uso do disco de dentina e preparos cavitários, enaltecendo as vantagens dos discos, principalmente no que se refere ao conhecimento das dimensões e espessura.

Neste estudo foram utilizados molares humanos inclusos de pacientes na faixa etária de 16 a 29 anos. A remoção do esmalte oclusal foi realizada com uma broca 556 em alta velocidade e abundante refrigeração, até criar uma superfície plana e paralela ao plano oclusal do dente. Esta superfície foi polida com lixa de papel e examinada com luz refletida com um aumento de seis vezes para averiguar a completa remoção do esmalte. A porção remanescente da coroa dentária foi seccionada com uma peça de mão paralela ao plano estabelecido e obtiveram-se discos de dentina com espessuras uniformes de 1,0mm. Os discos 
foram colocados em uma câmara desmontável (split-chamber) que permite a colocação de elementos radioativos de um lado e sua passagem contínua para o lado coletor. A superfície de dentina disponível para difusão era delimitada por pares de anéis de borracha com áreas de 0,071, 0,126, 0,221 e 0,292 $\mathrm{cm}^{2}$. Cada anel de borracha era firmemente posicionado junto ao disco de dentina pela split-chamber. A solução radioativa foi colocada na face oclusal e coberta com um anteparo para minimizar a evaporação. Os valores da permeabilidade foram calculados usando a equação de Fick. Dobrando a área de superfície, dobra a passagem do traçador pela dentina por intervalo de tempo. O aumento da temperatura da dentina de 25 para $30^{\circ} \mathrm{C}$ quase dobra a passagem do ${ }^{125} \mathrm{I}$. No que diz respeito à espessura, a redução do disco feita a partir da face oclusal aumenta a permeabilidade dentinária e a redução pela face pulpar resultou em pouco aumento da permeabilidade. O tempo pós-extração tem um efeito pequeno sobre a medição da permeabilidade in vitro.

GARBEROGLIO; BRÄNNSTRÖM ${ }^{14}$, em 1976, estudaram através de microscopia eletrônica de varredura o número e o diâmetro dos túbulos dentinários. Os autores afirmaram que o diâmetro dos túbulos pode variar de acordo com a região e com a técnica utilizada. Para tanto, realizaram o exame da dentina coronária fraturada de 30 dentes humanos hígidos de várias faixas etárias e a várias distâncias da polpa, bem como a diferença entre dentina descalcificada e não descalcificada. Próximo à polpa o número de túbulos por milímetro quadrado foi de 45.000 e o diâmetro de 2,5 $\mu \mathrm{m}$. Na região intermediária, o número foi de $29.500 / \mathrm{mm}^{2}$ e o diâmetro de $1,2 \mu \mathrm{m}$. Perifericamente os valores correspondentes foram de $20.000 / \mathrm{mm}^{2}$ e $0,9 \mu \mathrm{m}$. Não houve diferenças entre as faixas etárias examinadas. $O$ 
diâmetro dos túbulos aumentou consideravelmente nas superfícies descalcificadas, devido à remoção total da dentina peritubular. Em dentes jovens, próximo à polpa, houve grande variação no diâmetro dos túbulos, tanto de dente para dente quanto no mesmo dente (2 a $3,2 \mu \mathrm{m})$. A mesma variação foi encontrada em dentes de adultos. O processo odontoblástico foi visto somente em túbulos próximos à polpa.

Como parte do estudo sistemático das características da permeabilidade dentinária, MERCHANT; LIVINGSTON; PASHLEY ${ }^{27}$, em 1977, compararam a difusão de iodo com a filtração. Os discos utilizados, num total de seis, tinham 1,00 $\pm 0,06 \mathrm{~mm}$ de espessura uniforme. A superfície disponível para difusão ou filtração foi definida por anéis de borracha em $0,178 \mathrm{~cm}^{2}$. Todas as medições de filtração e difusão foram realizadas da face oclusal para a face pulpar, antes e após o condicionamento ácido. Durante a difusão, o tubo de polietileno ligado a split-chamber foi mantido numa posição horizontal sem nenhuma pressão aplicada sobre o disco, e após a obtenção do equilíbrio osmótico o tubo contendo o iodo foi posicionado $240 \mathrm{~cm}$ acima do disco, mantendo uma pressão hidrostática constante para filtração. Antes do condicionamento ácido, a proporção de iodo filtrado pela dentina foi duas vezes maior que a proporção obtida pela difusão. Após o condicionamento com ácido cítrico a $50 \%$ por 2 minutos em ambos os lados do disco, a filtração foi aumentada em 32 vezes em relação a difusão. 0 condicionamento ácido desobstrui os túbulos e facilita mais a filtração que a difusão. 


\section{PASHLEY; LIVINGSTON; GREENHILL ${ }^{53}$, em 1978,} compreendem que a resistência à movimentação do fluido no interior da dentina humana se deve a fatores como: 1) resistência superficial devido a presença de debris ocluindo os túbulos dentinários, 2) resistência intra-tubular por causa da presença de nódulos mineralizados e túbulos tortuosos e 3) resistência pulpar representada pelos odontoblastos. O objetivo do estudo foi estimar a contribuição de cada um desses fatores na resistência total da movimentação do fluido. Para isso, foram preparados segmentos de coroas a partir de molares humanos inclusos, recém-extraídos, os quais foram submetidos ao processo de filtração. Os espécimes foram colocados numa split-chamber com área oclusal exposta de $0,178 \mathrm{~cm}^{2}$. A resistência total à movimentação do fluido foi medida pela filtração dos segmentos de coroas recém-preparados. A polpa foi removida e foi feita nova medição da filtração. A diferença entre estas filtrações foi considerada como sendo a resistência oferecida pelo tecido pulpar. A terceira medição foi feita após o condicionamento com ácido cítrico a 50\% por 2 minutos. E a diferença entre estas filtrações (antes e após o condicionamento ácido) foi resultado da remoção de fragmentos oclusivos da superfície dentinária. Finalmente, a última medição da filtração foi realizada após 7 dias da obtenção dos espécimes. Em cada uma das medições houve variações do direcionamento da aplicação da pressão hidrostática, primeiramente do esmalte para a polpa, depois da polpa para o esmalte e novamente na primeira situação.

A resistência de superfície (Rs) foi responsável por $86,44 \%$ da resistência total $(\mathrm{Rt})$, a resistência do tecido pulpar $(\mathrm{Rp})$ por $7,48 \%$ e a resistência intra-tubular (Ri) foi calculada pela diferença entre a resistência total e as resistências obtidas no experimento: $R i=R t-(R s+R p)$. A resistência à 
movimentação do fluido variou com a direção da aplicação da pressão, sendo menor quando aplicada do esmalte para a polpa.

PASHLEY et al. $^{60}$, em 1978, estudaram o efeito das modificações da superfície dentinária no coeficiente de permeabilidade da água e albumina marcadas. Doze discos de dentina foram preparados a partir de molares humanos inclusos, usando discos de diamante, obtendo-se espessuras uniformes de $1 \pm 0,05 \mathrm{~mm}$ e com um acabamento liso. Os discos foram posicionados numa splitchamber, e a área disponível para difusão foi de $0,317 \mathrm{~cm}^{2}$. Todo o fluxo de difusão foi medido da face oclusal para a face pulpar. A superfície dentinária recebeu os seguintes tratamentos: 1) superfície lisa como resultado da ação do disco de diamante, 2) asperização da superfície com broca 558, 3) condicionamento com ácido cítrico a $50 \%$ por 2 minutos e 4) tratamento da dentina condicionada com solução de oxalato de potássio monohidratado por 2 minutos no lado oclusal. A asperização da superfície dentinária reduziu a espessura em apenas $0,05 \mathrm{~mm}$.

Os valores de difusão da água foram maiores devido a grande concentração e ao tamanho reduzido das moléculas. A asperização não produziu mudanças estatisticamente significantes na passagem dos isótopos. $O$ condicionamento ácido aumentou o fluxo significativamente e o tratamento com oxalato de potássio reduziu significativamente o fluxo de isótopos.

A área disponível para difusão foi calculada e expressa em porcentagem para a água e albumina. Os espécimes com acabamento liso tiveram áreas de superfície de 1,72 e 0,74\% para a água e albumina, respectivamente. A proporção entre estas áreas de superfícies $(2,32)$ sugeriu um grau maior de restrição 
para a albumina, que tem um raio molecular de 37 , do que para a água, com raio de 1,9. Quando a superfície lisa foi asperizada com broca, não houve mudanças estatísticas significantes para a área de difusão. Após o condicionamento ácido, a área de difusão da água aumentou para $7,89 \%$ e da albumina para 6,3\%. A proporção entre as áreas é pequena $(1,25)$, indicando que a desobstrução dos túbulos diminuiu a restrição da difusão da albumina. O tratamento com oxalato reduziu a área de difusão próximo aos valores controles (2,24\% para água e 1,44\% para albumina), e a proporção entre as áreas de difusão $(1,56)$ não mudou, indicando não haver restrições diferentes para a água e a albumina.

MICHELICH; PASHLEY; WHITFORD ${ }^{29}$, em 1978, relataram a existência de duas teorias para se quantificar a sensibilidade dentinária: 1) estimulação direta dos receptores neurais nos túbulos dentinários e 2) estimulação indireta dos receptores pela movimentação dos fluidos no interior dos túbulos. A última foi proposta por Brännström e é geralmente referida como a teoria hidrodinâmica da dentina sensível. Caso a movimentação do fluido seja responsável pela sensibilidade dentinária é necessário examinar fatores físicos que regulam esta movimentação nos fluidos dentinários. De acordo com a lei de Poiseulle a proporção de volume movimentada é dada por : Jv $=\operatorname{Pr}^{4} / 8 \mathrm{nl}$. A movimentação do fluido é diretamente proporcional a quarta potência do raio dos túbulos. Pequenas mudanças no raio produzem grandes alterações na proporção da movimentação do fluido.

As técnicas de filtração e tensão superficial foram usadas para medir o raio funcional dos túbulos de 11 discos de dentina e 2 discos de vidro. Estes valores foram comparados com a determinação do raio por microscopia 
eletrônica de varredura, e mostraram-se bem menores que o raio anatômico. O raio funcional dos discos de dentina variaram de 5 a $40 \%$ do raio anatômico. A diferença ocorreu pois na MEV visualizava-se apenas a aparência superficial, enquanto que nas técnicas utilizadas as medições eram feitas levando-se em consideração toda a extensão dos túbulos. As duas técnicas apresentaram estimativas razoáveis do raio funcional dos discos de dentina e valores precisos para os discos de vidro, no qual os raios anatômico e funcional são idênticos. Os dados dos discos de vidro confirmaram a confiabilidade destes métodos para a medição do raio. Estas observações in vitro com os discos de dentina podem ser diferentes das obtidas in vivo por causa da existência do processo odontoblático no interior dos túbulos. Entretanto, eles concluíram que os métodos funcionais (filtração e tensão superficial) são preferidos sempre que a movimentação do fluido de dentina for considerada. Os métodos de filtração e tensão superficial produziram valores diferentes para determinação do raio funcional dos túbulos. Os dados obtidos com a filtração refletem mais corretamente o verdadeiro significado do raio funcional.

REEDER et al. ${ }^{71}$, em 1978, concordam que um ponto crítico nos estudos da movimentação de fluidos pela dentina é a medição da filtração feita sem o controle das variáveis. Não há uniformidade nas características da dentina, quer de espessura ou de área de superfície a ser estudada. A condutividade hidráulica da dentina deve ser quantificada para descrever a facilidade da passagem do fluxo pela dentina. Por definição, condutividade hidráulica traduz a facilidade com que o fluido, sob uma pressão hidrostática ou osmótica, pode passar pela dentina sob condições definidas. O propósito deste trabalho foi determinar quantitativamente 
a passagem do fluido pela dentina, sob várias pressões hidrostáticas, e determinar a influência da área de superfície e da espessura na proporção de filtração. Os discos de dentina foram colocados numa câmara apropriada, e anéis de borracha vedavam a câmara dos discos e controlavam a área de superfície da dentina. A pressão hidrostática foi aplicada de um lado da câmara direcionando a filtração para o outro lado. Deste modo, a filtração foi medida como deslocamento do fluido numa micropipeta conectada à câmara. A variação da pressão foi controlada pelo peso colocado no disco. Todas as medições foram realizadas por três vezes consecutivas e uma média aritmética foi obtida. Discos não condicionados e condicionados (ácido cítrico $50 \%$ - 2min.) foram submetidos a pressões hidrostáticas de 60, 120 e $240 \mathrm{cmH}_{2} \mathrm{O}$, permitindo uma comparação direta entre estas situações no mesmo disco. Em relação à espessura, os discos foram reduzidos de $0,99 \mathrm{~mm}$ para 0,86 , 0,74 e 0,61mm pelo uso de lixas na face oclusal. Após cada redução os discos eram condicionados e media-se a filtração, modificando-se também a área de dentina exposta de $0,079,0,178$ e $0,317 \mathrm{~cm}^{2}$. Este procedimento objetivava saber as variações da filtração quando submetidas a espessuras diferentes dos espécimes, bem como a inter-relação espessura $X$ área de superfície.

O cálculo da condutividade hidráulica foi feito pela fórmula Lp $=\mathbf{Q} / \mathbf{P}$ (A.S.), pois como a micropipeta tem um diâmetro interno constante, dividindo sua capacidade pelo seu comprimento obtêm-se uma proporcionalidade que converte deslocamento linear em deslocamento volumétrico.

Os resultados demonstraram que os espécimes não condicionados apresentaram uma condutividade hidráulica baixa e com crescimento linear em função da modificação da pressão, enquanto espécimes condicionados 
apresentaram filtrações 32 vezes maior. A redução da espessura dos discos aumentou o índice de filtração e, com relação à área de superfície $X$ espessura, os dados demonstram que em cada área de superfície, quando os discos eram reduzidos pela face oclusal, havia um aumento progressivo na filtração. Além disso, em cada espessura, quando a área de superfície aumentava, havia um aumento linear na filtração. Os autores sugeriram a realização de novos estudos, devido a grande variação nas condições estipuladas nesta investigação.

PASHLEY; LIVINGSTON ${ }^{48}$, em 1978, utilizaram substâncias de diferentes tamanhos moleculares para avaliar a relação existente entre aumento do tamanho molecular e a permeabilidade dentinária. As substâncias testadas foram água, uréia, flúor, lidocaína, glicose, sacarose, inulina, dextrano, clorexidina, polivinilpirolindone e albumina. O aumento do tamanho do raio molecular em 19 vezes $(1,9 \AA ̊$ a $37 \AA ̊)$ resultou numa diminuição de 100 vezes na permeabilidade dentinária. Após o condicionamento ácido, o coeficiente de permeabilidade da água aumentou cerca de 4 vezes de $2,74 \times 10^{-4}$ para $1,17 \times 10^{-3} \mathrm{~cm} / \mathrm{min}$ e da albumina aumentou 9 vezes de $2,79 \times 10^{-6}$ para $2,56 \times 10^{-5} \mathrm{~cm} / \mathrm{min}$. Tanto o flúor quanto a clorexidina tiveram coeficientes de permeabilidade muito reduzidos em relação ao peso e tamanho molecular, sugerindo uma ligação à dentina.

\section{PASHLEY; LIVINGSTON; WHITFORD ${ }^{54}$, em 1979,} afirmaram que o grau de semipermeabilidade da dentina pode ser quantificado pela medição da pressão osmótica efetiva da solução que passa pela dentina, dividindo-a 
pela pressão osmótica teórica. Esta razão é conhecida como o coeficiente de reflexão e varia de 0 , quando a membrana não tem distinção entre a permeabilidade do soluto e a do solvente, a 1, quando somente a água ou solvente é filtrada. A pressão osmótica efetiva de soluções contendo solutos de vários tamanhos moleculares foi determinada em três condições: na presença de smear-layer, com condicionamento ácido e após o tratamento com oxalato de potássio. O coeficiente de reflexão dos espécimes com smear layer aumentou proporcionalmente com o tamanho da molécula, de $3 \times 10^{-4}$ para sacarose para 0,38 para albumina. 0 condicionamento ácido produziu uma diminuição no coeficiente de reflexão na ordem de 5 a 9 vezes(aumentando a permeabilidade) mas o tratamento com oxalato retornou os valores aos níveis estabelecidos pela smear layer.

PASHLEY; WHITFORD ${ }^{50}$, em 1980, descreveram um método para medida das pressões osmóticas efetivas de soluções que passam através da dentina, determinando que a razão entre a pressão osmótica efetiva e a teórica é chamada de coeficiente de reflexão. Esse valor varia de 0 , indicando falta de discriminação entre soluto e água, a 1, indicando completa impermeabilidade ao soluto, ou seja $100 \%$ do soluto é barrado. Nas várias soluções estudadas, o coeficiente de reflexão esteve em torno de 0,0001, com a pressão osmótica efetiva das soluções sendo menor do que suas pressões teóricas. O uso de coeficientes de reflexão permite estimar a pressão osmótica efetiva de soluções de baixo peso molecular. Os baixos índices de reflexão obtidos no estudo indicam que a dentina não discrimina de uma maneira eficaz entre água e os solutos de baixo peso molecular, mas formaliza o seu grau de semipermeabilidade. Na dentina, o 
coeficiente de reflexão da uréia, alguns sais e açúcares está em torno de 0,0001. Deste modo a pressão osmótica efetiva destas soluções estão somente a $10^{-4}$ de suas pressões osmóticas teóricas.

\section{BRÄNNSTRÖM; NORDENVALL; GLANTZ ${ }^{7}$, em 1980,} estudaram a capacidade de remoção de smear layer pelo EDTA e uma solução ativa em 132 dentes humanos preparados com ponta diamantada em alta velocidade. Os preparos foram feitos sob refrigeração até a exposição de uma área de 1,5 a $2 \mathrm{~mm}^{2}$. Duas situações experimentais foram realizadas. Na primeira, a superfície dentinária foi obtida com refrigeração ar/água, e a segunda, somente com ar, tendo metade dos dentes em condição umedecida e outra metade com smear layer ressecada. Cinco soluções foram utilizadas: 1) Tubulicid, 2) Experimental com 0,2\% de EDTA, 3) Experimental com 0,15\% de EDTA, 4) Experimental com 0,1\% de EDTA e 5) EDTA $0,2 \%$. Os resultados mostram que a combinação de EDTA $(0,15$ e $0,2 \%)$ com solução antibacteriana ativa tem a capacidade de remover a smear layer sem ampliar a abertura dos túbulos ou remover a dentina peritubular. Os resultados de limpeza foram melhores quando foi usada uma combinação de soluções. Não houve diferenças estatísticas na remoção da smear layer nas condições úmida e ressecada.

PASHLEY et al. ${ }^{61}$, em 1981, descreveram um sistema que pode ser usado para determinar e comparar quantitativamente as características de permeabilidade dentinária em cães tanto in vivo como in vitro no mesmo dente. Os cães eram anestesiados e as artérias e veias femurais foram canuladas de um lado 
para permitir registro contínuo da pressão sanguínea. Os dentes foram reduzidos com ponta diamantada em alta velocidade e abundante refrigeração num plano paralelo ao longo eixo. A espessura de dentina era limitada pela visualização dos cornos pulpares através da dentina remanescente. A dentina recebia um acabamento com disco de granulação fina e com refrigeração, obtendo superfícies planas para boa adaptação da câmara cônica utilizada. Esta câmara era unida ao dente com cianoacrilato azul e reforçada com cimento de policarboxilato de zinco. A transparência e a conicidade da câmara facilitam a detecção e remoção de bolhas de ar. Aproximadamente $200 \mu$ l de solução salina marcada com isótopos radioativos $\left({ }^{45} \mathrm{I}\right)$ eram colocados na câmara. Após a realização dos testes in vivo, os dentes eram extraídos com cuidado, para não remover a câmara e possibilitar seu uso nos experimentos in vitro.

Os dados indicaram que o iodo radioativo colocado em contato com a dentina foi absorvido rapidamente pela circulação pulpar. $\mathrm{O}$ acúmulo de isótopos no plasma sugere que a absorção é mais rápida que a eliminação. $\mathrm{O}$ acúmulo de isótopos radioativos foi similar para os testes in vivo e in vitro, comprovando a eficiência deste método para medir o transporte de isótopos pela dentina.

PASHLEY; MICHELICH; KEHL ${ }^{55}$, em 1981, relataram a importância da utilização de soluções ácidas no emprego dos sistemas restauradores adesivos para a obtenção de união adequada entre estrutura dentária e material restaurador. Este estudo examinou a superfície de dentina antes e depois 
do condicionamento com ácido cítrico para a remoção da smear layer através de microscopia eletrônica de varredura.

Vinte discos de dentina foram obtidos a partir de terceiros molares humanos, usando disco de diamante. Os dentes foram cortados em dois locais, numa posição perpendicular ao longo eixo da raiz. O primeiro corte localizado no limite apical do esmalte e o segundo no limite coronal da câmara pulpar. Deste modo os discos constituem de uma secção de dentina circundada por esmalte periférico. Os discos foram lixados pela face oclusal a uma espessura uniforme de 1 $\pm 0.05 \mathrm{~mm}$. A face pulpar do disco foi condicionado por $1 \mathrm{~min}$. com ácido cítrico a $50 \%$, para abertura dos túbulos e simulação das condições in vivo. Cada disco foi colocado no interior da split-chamber com solução apropriada em cada lado. A pressão hidrostática foi aplicada e a filtração (da face oclusal para a face pulpar do disco) foi medida como resultado do deslocamento do volume na micropipeta. Os discos foram condicionados na face oclusal no interior da câmara por 5, 15, 30, 45 e 60 s com ácido cítrico a $6 \%$ que foi imediatamente lavado. A proporção de filtração foi definida e os discos foram condicionados por outro período de tempo. Desde que a micropipeta usada para medir a proporção de filtração $(L p)$ tem um diâmetro interno constante, dividindo-se o volume da pipeta por seu comprimento obtêm-se uma proporção constante que converte deslocamento linear em deslocamento de volume.

Os resultados indicam que o condicionamento com ácido cítrico a $6 \%$ por 5 e 15 segundos remove parte da smear layer, mas a maioria dos túbulos permanece ainda obstruído. O condicionamento por 60 segundos remove toda smear layer e amplia a abertura dos túbulos em 3 a 4 vezes. No que diz respeito à filtração, o condicionamento por 5 segundos proporcionou um aumento 
estatisticamente significante da filtração em relação aos discos não condicionados. O condicionamento por 15 segundos aumentou ainda mais o índice de filtração, mas tempos adicionais de condicionamento (30 e 60s), embora removesse a smear layer remanescente não provocou aumento nos índices de filtração.

GREENHILL; PASHLEY ${ }^{19}$, em 1981, avaliaram in vitro a habilidade de agentes dessensibilizantes na redução da movimentação do fluido pela dentina. Cento e vinte e três discos de dentina de $1 \mathrm{~mm}$ de espessura foram obtidos a partir de molares humanos inclusos. Os discos foram imersos em solução de ácido cítrico a 50\% por 2 minutos, para remoção dos fragmentos que obliteram os túbulos, e posicionados numa câmara de filtração com área exposta de $0,178 \mathrm{~cm}^{2}$. A filtração da solução pela dentina foi medida sob uma pressão de $240 \mathrm{cmH}_{2} \mathrm{O}$. O lado oclusal do disco foi tratado com agentes dessensibilizantes para determinar a redução da movimentação de líquidos. Os discos que reduziram a filtração mais que $50 \%$ foram examinados em MEV para verificar se esses agentes estavam ocluindo parcialmente os túbulos. O oxalato de potássio a $30 \%$ obteve o melhor resultado na redução da permeabilidade dentinária, alcançando níveis de redução de 98,4\%.

PASHLEY et al. ${ }^{62}$, em 1981, calcularam o coeficiente de reflexão de capilares pulpares para proteínas plasmáticas usando o fluxo de proteínas obtido do fluido dentinário. O fluido dentinário foi coletado de cavidades circulares realizadas com broca cone invertido \#34 com área exposta de 0,123 a $0,13 \mathrm{~cm}^{2}$ em primeiros molares de cães. A coleta do fluido foi realizada antes e depois da administração de histamina. O fluido dentinário e o plasma foram 
analisados pela proteína total e as concentrações relativas destes dois fluidos foram comparadas. Assumindo que a concentração da proteína no fluido dentinário é similar a do fluido intersticial pulpar ao redor dos capilares, o coeficiente de reflexão das proteínas plasmáticas para os capilares pulpares foi calculada. Após o preparo cavitário, os capilares pulpares estavam bastante impermeáveis à proteína, mas tornaram-se mais permeáveis após a administração da histamina. Não houve diferenças na concentração de proteínas das amostras coletadas da dentina ou diretamente da polpa, indicando que o fluido dentinário pode ser usado para determinar a composição do fluido intersticial pulpar.

PASHLEY; NELSON; PASHLEY ${ }^{57}$, em 1981, mediram a movimentação de fluido pela dentina de cães através da medição da pressão pulpar com a dentina intacta in vivo. Desgastes nas superfícies vestibulares de primeiros molares e caninos foram realizados até a visualização da câmara pulpar. A superfície dentinária ficava a mais plana possível para permitir a adaptação e cimentação de uma câmara cônica. As medições foram feitas três vezes para cada pressão hidrostática utilizada para movimentação do fluido. Pressões hidrostáticas positivas produziram a movimentação do fluido em direção ao dente, enquanto que pressões hidrostáticas negativas permitiam a movimentação do fluido do dente para a câmara. A aplicação da pressão foi sempre nesta ordem: pressão positiva, seguida de pressão negativa e novamente pressão positiva. A conexão da câmara a um medidor de pressão possibilitou a medição da pressão intra-pulpar na dentina intacta, que teve como média, $24 \mathrm{mmHg}$. O conhecimento das pressões intra e extra pulpares permitiu o cálculo da condutividade hidráulica in vivo da dentina de cães, a 
qual foi de $1,35 \times 10^{-2}$ para molares e $4,51 \times 10^{-3}$ para caninos. Os valores foram estatisticamente significantes maiores para os molares embora a espessura de dentina remanescente tenha sido igual. Não houve diferenças estatísticas significantes entre as pressões utilizadas, embora a Lp para pressões negativas, movimentação do fluido da polpa para a superfície, tenham sido menores.

PASHLEY; NELSON; KEPLER ${ }^{56}$, em 1982, estudaram a influência da saliva, suspensões bacterianas e proteínas plasmáticas na movimentação de fluidos em discos de dentina. Neste experimento foram utilizados molares humanos de pacientes entre 16 e 29 anos. Os dentes foram armazenados em solução salina congelada e o período de armazenamento foi de 1 a 60 dias. Os discos de dentina foram obtidos pelo corte de 23 dentes com disco diamantado com espessuras de $1 \pm 0,01 \mathrm{~mm}$. Todos os discos foram condicionados com ácido cítrico a 50\% por 2 min. para assegurar a completa remoção da smear layer e simulação das condições in vivo. Os discos foram posicionados numa câmara com solução salina tamponada por fosfato em ambos os lados. A área disponível para filtração foi de $0,283 \mathrm{~cm}^{2}$ e a pressão de $200 \mathrm{cmH}_{2} \mathrm{O}$. Todas as filtrações foram determinadas antes e depois do tratamento com as soluções. Plasma, soro e constituintes plasmáticos foram aplicados na face pulpar do disco por 5 min., antes de ser filtrado pela dentina por $15 \mathrm{~min}$. a $200 \mathrm{cmH}_{2} \mathrm{O}$. A saliva foi utilizada da mesma forma, mas pela face oclusal. As medições pós-tratamento só foram realizadas depois da remoção das soluções testadas da câmara e lavagem com grande quantidade de solução salina. Todas as filtrações foram feitas com a mesma solução para manter a viscosidade do sistema. 
O tratamento só com solução salina tamponada por fosfato não afetou a condutividade dentinária. O plasma reduziu a $\mathrm{Lp}$ em $77 \%$ e o soro em $54 \%$. Desde que a maior diferença entre plasma e soro é a falta de fibrinogênio e plaquetas, cada um dos constituintes foram testados separadamente. O fibrinogênio reduziu a Lp em $69 \%$ e as plaquetas $81 \%$. O soro contém outras substâncias de alto peso molecular, além do fibrinogênio que contribui para a redução da Lp. A saliva oriunda da parótida teve pouco efeito na Lp, comparada com a da submandibular (27\%). A saliva total (sublingual, glândulas salivares menores e bactérias) reduziram a Lp em $65 \%$. A redução da Lp pelas suspensões bacterianas está na dependência da concentração.

\section{PASHLEY; THOMPSON; STEWART ${ }^{59}$, em 1983,} estudaram a influência da temperatura na condutividade hidráulica da dentina condicionada e não condicionada, através de experimento in vitro. Os discos de dentina foram preparados como no método anterior e posicionado numa câmara com área exposta de $0,286 \mathrm{~cm}^{2}$. A porção inferior era fechada e apresentava um orifício para entrada de pressão, enquanto que a porção superior era aberta. Uma micropipeta foi interposta entre um reservatório de água e a câmara para permitir a mensuração da movimentação de fluido do sistema. A pressão aplicada foi de $200 \mathrm{cmH}_{2} \mathrm{O}$ da face pulpar para a face oclusal. A água foi utilizada para passar nos túbulos, para evitar diferenças de pressão osmótica de outras soluções isotônicas. Foram utilizados 8 discos de dentina, 4 discos nas temperaturas de 10, 20 ,30, 40 e $50^{\circ} \mathrm{C}$, e os outros 4 em ordem de temperatura inversa. A cada medição houve um intervalo de 30 minutos, para permitir o equilíbrio térmico do sistema. Cinco medidas 
foram feitas para cada temperatura. Na condição sem condicionamento a face pulpar do disco foi condicionado com ácido cítrico a $50 \%$ por 2 min. e a face oclusal ficou intacta. Após o condicionamento da face oclusal procederam-se novas medições.

Houve um aumento da Lp quando a temperatura aumentava para os discos não condicionados e condicionados. O condicionamento ácido aumentou a Lp em 41X. O aumento da Lp para ambos os grupos foi expresso como uma diferença de porcentagem dos dados de $10^{\circ} \mathrm{C}$ para as demais temperaturas. A Lp dos espécimes não condicionados aumentou $179 \%$ de 10 a $50^{\circ} \mathrm{C}$ e a $\mathrm{Lp}$ dos espécimes condicionados aumentou $406 \%$ de 10 a $50^{\circ} \mathrm{C}$. Este aumento deveu-se à alteração da viscosidade do líquido e o diâmetro dos túbulos. Quanto maior a temperatura menor a viscosidade e maior o diâmetro dos túbulos.

PASHLEY et al. ${ }^{63}$, em 1983, testaram 0 efeito do condicionamento ácido da dentina na proporção da movimentação do fluido in vivo e determinaram se a proporção obtida após o condicionamento ácido era maior do que a microcirculação pulpar poderia acomodar. Cavidades circulares foram preparadas na superfície vestibular de primeiros molares inferiores de 11 cães de ambos os sexos. Na superfície de dentina foi fixado uma câmara cônica, a qual continha solução salina tamponada por fosfato e $0,02 \%$ de corante fluorescente. A área de superfície foi constante, e igual a $0,243 \mathrm{~cm}^{2}$. A pressão pulpar foi medida no final de cada filtração e a pressão hidrostática externa foi de $200 \mathrm{cmH}_{2} \mathrm{O}$. As medições de cada filtração foram triplicadas e os dados expressos em condutividade hidráulica. A condutividade hidráulica foi determinada antes e depois do condicionamento ácido com ácido cítrico a 50\% por 2 minutos. Depois disso, a medição da condutividade 
hidráulica era feita no dente intacto, através da abertura da câmara pulpar pelo lado lingual e redeterminação da condutividade hidráulica. Deste modo cada dente servia como seu próprio controle para efeito do condicionamento ácido e abertura da câmara pulpar na movimentação do fluido pela dentina.

Os dados indicam que o condicionamento ácido da dentina resultou num aumento de $5 X$ na permeabilidade dentinária (Lp), sendo estatisticamente significante $(p<0,001)$. Houve uma grande variação na resposta, entretanto, era dependente da $L p$ inicial. A correlação entre $L p$ inicial e diferença de porcentagem em Lp, seguido do condicionamento ácido mostrou uma relação inversa, ou seja, quanto menor a $\mathrm{Lp}$ maior a diferença de porcentagem após o condicionamento. Não houve correlação entre a espessura da dentina e a Lp antes e depois do condicionamento ácido. A abertura da câmara pulpar levou a pressão pulpar a zero e a mudança da Lp comparada com o condicionamento ácido não foi estatisticamente significante.

PASHLEY et al. ${ }^{64}$, em 1984, determinaram o efeito de vários dentifrícios dessensibilizantes na movimentação do fluido pela dentina, in vitro, pela medição da condutividade hidráulica da dentina. Os discos de dentina foram preparados como descrito por REEDER et al. ${ }^{71}$ em 1978. Para aumentar a permeabilidade dentinária e simular hipersensibilidade dentinária, os discos, antes dos testes, foram condicionados com ácido cítrico a 6\% por 2 minutos para remoção da smear layer. Os discos condicionados foram posicionados numa split-chamber com área exposta de $0,282 \mathrm{~cm}^{2}$. O fluido usado para filtração foi solução salina tamponada por fosfato estéril sob uma pressão de $200 \mathrm{cmH}_{2} \mathrm{O}$. A movimentação do 
fluido era sempre da face pulpar para a face oclusal, que tenderia a desalojar os constituintes do dentifrício dos túbulos. Os dentifrícios utilizados foram: Thermodent, Sensodyne, Promise, Denquel, Crest e um experimental contendo oxalato. Dentifrícios placebo foram obtidos para todos, exceto para o Thermodent. Cada dentifrício foi diluído nas proporções (1:3, 1:1 e 3:1), partes de dentifrício para água destilada. Uma quantidade de $0,2 \mathrm{ml}$ de dentifrício foi colocada na câmara e abrasionada por 1 minuto e 120 rotações e, em seguida lavada para remover qualquer resquício do creme dental. A Lp foi medida após o condicionamento ácido para cada disco, bem como para a solução salina tamponada por fosfato (por 1 minuto e 120 ciclos), e os dados obtidos para cada diluição de dentifrício foram comparados com os dados da solução controle.

Os dados foram expressos em diferença de porcentagem para permitir comparação entre os discos. Os dados dos 3 a 6 discos usados para cada experimento foram expressos em média e desvio padrão dos valores controles. Todos os dentifrícios diminuíram a Lp da dentina. O dentifrício experimental contendo oxalato como componente ativo foi mais efetivo que os dentifrícios comerciais. Não houve diferenças estatisticamente significantes entre os dentifrícios e os placebos, exceto para o dentifrício com oxalato, que reduziu cerca de $95 \%$ em relação aos outros.

PASHLEY; STEWART; GALLOWAY ${ }^{58}$, em 1984, avaliaram a capacidade com que o fluido se desloca através da dentina in vitro, tendo como variáveis o tipo de líquido para filtração (água, soro fisiológico, solução aquosa de albumina e albumina em soro fisiológico) e a resposta a jatos de ar de 0,5, 2 ou 5 
minutos de duração. Os discos de dentina foram preparados pelo método de REEDER et al. ${ }^{71}$ e posicionados numa split-chamber, permitindo que o lado oclusal do disco ficasse em contato com o meio ambiente. A área de disco exposta era limitada por anéis de borracha com área de $0,282 \mathrm{~cm}^{2}$. Todos os fluidos foram préfiltrados num filtro miliporo de $0,2 \mu \mathrm{m}$. A movimentação do fluido era feita da face pulpar para a face oclusal, com pressão constante de $30 \mathrm{cmH}_{2} \mathrm{O}$. Todos os discos foram condicionados com ácido cítrico a $6 \%$ por 2 minutos na face pulpar e a face oclusal foi deixado intacta. Nos quatros grupos do experimento houve a variação de solução usada para filtração, com as medições realizadas com a smear layer intacta e com pressão de $30 \mathrm{cmH}_{2} \mathrm{O}$. As medições seguintes foram feitas após a exposição dos discos a jatos de ar com duração de 0,5, 2 e 5 minutos. Para cada condição foram realizadas três medições da condutividade hidráulica. O mesmo protocolo foi seguido para os discos condicionados. Com a água destilada não houve efeito da evaporação na permeabilidade dentinária. Para a solução fisiológica, a redução da Lp foi dependente do tempo de aplicação do jato de ar. O grupo da solução aquosa de albumina foi que reduziu a permeabilidade dentinária a níveis menores. Estes efeitos foram mais marcantes para os discos não condicionados do que para os condicionados.

BOWEN et al. ${ }^{4}$, em 1984, examinaram através de microscopia eletrônica de varredura e microscopia eletrônica de transmissão a superfície de dentina com smear layer. Para este estudo foram utilizados terceiros molares seccionados com disco de diamante, e o remanescente desgastado em lixa abrasiva 320 com movimentos para frente e para trás e com pressão manual. Os 
resultados sugeriram que o corte e abrasionamento dos dentes alteram a estrutura dentinária a uma profundidade de até $3 \mu \mathrm{m}$. O colágeno intra-tubular parece estar desnaturado até a uma profundidade de $1 \mu \mathrm{m}$ enquanto que a espessura da smear layer variou de 0,1 a $1 \mu \mathrm{m}$. Material orgânico foi visto no lúmen dos túbulos, próximo à área preparada.

PASHLEY $^{38}$, em 1984, descreveu a smear layer como resultado do uso de instrumentos manuais e rotatórios na redução da estrutura dentária, e esta redução deposita sobre a superfície dentária os fragmentos de partículas da matriz de colágeno mineralizada. A smear layer não aparece nos espécimes observados por microscopia ótica convencional, pois é dissolvida durante a desmineralização. Quando examinado por microscopia eletrônica de varredura a smear layer tem aparência amorfa, relativamente lisa e sem características. A smear layer mais espessa $(10-15 \mu \mathrm{m})$ foi produzida in vitro com uma lâmina de diamante abrasiva. Este dispositivo tende a obliterar e polir os fragmentos, num acabamento liso e brilhante. A smear layer aumenta a resistência a movimentação de fluidos pela dentina tanto in vivo como in vitro. A proporção de filtração de fluido é um método conveniente de se quantificar e avaliar a presença de smear layer, por isso, têm sido utilizada para comparar vários métodos de produção de smear layer na dentina atacada com ácido in vitro.

A presença da smear layer tem uma grande influência na permeabilidade dentinária. A difusão de substâncias pela dentina é proporcional à área disponível para difusão e ao seu gradiente de concentração. A área disponível para difusão na dentina é determinada pela densidade dos túbulos dentinários, que 
é o número de túbulos por milímetro quadrado e pelo diâmetro dos túbulos. Ambos valores variam de acordo com a distância da câmara pulpar. A área real de superfície de difusão é o resultado do produto da densidade dos túbulos pela área de cada túbulo. Esta área pode variar de 1 a $22 \%$ em média, da junção amelodentinária até próximo à região pulpar. Estas áreas foram calculadas em superfície de dentina fraturada, livre de fragmentos. Esta condição raramente é vista na clínica, exceto quando a dentina é condicionada com ácidos. A aparência da smear layer em microscopia eletrônica de varredura parece ser impermeável, no entanto, experimentos in vivo e in vitro têm demonstrado que solutos de vários tamanhos moleculares, marcados com isótopos, penetram facilmente a smear layer. É muito importante distinguir transporte de materiais por difusão e filtração. A difusão varia com o quadrado do raio, desde que a área de secção do túbulo é $\pi r^{2}$. Ela ocorre de áreas de alta concentração para áreas de baixa concentração e durante a difusão a concentração de substâncias é dissipada em função da distância. Portanto, a concentração de produtos microbianos que penetram na câmara pulpar através dos túbulos dentinários é apenas uma fração desses agentes na superfície de dentina. O transporte de materiais pela dentina por filtração é devido a presença de gradiente de pressão. Na filtração não ocorre mudança na concentração de substâncias dissolvidas no fluido, porque o fluido e tudo que está dissolvido nele é movimentado de um lado para outro. A força que movimenta é a pressão que é dissipada pela distância. O transporte pela dentina por filtração varia com a quarta potência do raio. Deste modo , a filtração é mais sensível à obstrução de túbulos (presença ou ausência de smear layer). 
MJÖR ${ }^{30}$, em 1985, relata que a camada superficial de dentina exposta por desgaste, torna-se coberta por smear layer e que o deslocamento do conteúdo dos túbulos ou dos odontoblastos é uma alteração característica nos componentes orgânicos. A destruição ou degeneração odontoblástica pode levar a uma falta ou redução da formação de pré-dentina. A estrutura da interface entre dentina e formações localizadas de dentina secundária irregular varia consideravelmente. Se não houver comunicação tubular entre dentina primária e secundária, a interface agirá como uma barreira impermeável. Alterações na dentina incluindo formação irregular de dentina secundária afetam a permeabilidade do tecido. Tais alterações são clinicamente importantes para o resultado de todos os tipos de trabalhos restauradores realizados nos dentes vitais.

PASHLEY $^{39}$, em 1985, realizou uma abordagem fisiológica da permeabilidade do complexo dentina/pré-dentina, e afirmou que os túbulos dentinários constituem o maior canal para difusão de solutos pela dentina. A passagem de substâncias pela dentina é proporcional ao produto do número de túbulos pelo diâmetro e ambos aumentam quando os túbulos convergem para a polpa, e desta forma a permeabilidade dentinária aumenta rapidamente quando se aproxima da câmara pulpar. A presença de smear-layer na superfície dentinária diminui a permeabilidade dentinária, especialmente por filtração de fluídos. 
THOMAS $^{78}$, em 1985, num estudo de revisão sobre a biologia pulpar e dentinária relata que o complexo dentina/pré-dentina como todo tecido conjuntivo é caracterizado pela presença de células e uma matriz extracelular. A dentina representa a porção mineralizada desta matriz extra-celular, enquanto a pré-dentina, a qual não é mineralizada, separa o componente mineralizado dos odontoblastos, as células responsáveis pela formação do tecido.

A característica mais importante da dentina é a presença de túbulos dentinários os quais se estendem perifericamente desde a junção odontoblasto pré-dentina por toda a espessura desse tecido. A permeabilidade dentinária é uma consequência direta da presença de túbulos. O número de túbulos dentinários varia de 45.000 a $65.000 / \mathrm{mm}^{2}$ na região próxima a polpa, 29.500 a $35.000 / \mathrm{mm}^{2}$ na região mediana e de 15.000 a $20.000 / \mathrm{mm}^{2}$ próximo ao limite amelodentinário. Essa aparente diminuição no número de túbulos está relacionada com o aumento da área de superfície de dentina em direção à junção amelodentinária. O diâmetro dos túbulos na região pulpar é de 2 a $3 \mu m$, e próximo ao limite amelodentinário é de 0,5 a $0,9 \mu \mathrm{m}$. O túbulo dentinário é composto por: dentina peritubular, processo odontoblástico, colágeno, nervos e fluido dentinário. Estes componentes de alguma maneira influenciam na permeabilidade dentinária.

PASHLEY; GALLOWAY ${ }^{47}$, em 1985, avaliaram o efeito do tratamento com oxalato de potássio em superfícies de dentina. Sessenta discos de dentina foram cortados de terceiros molares humanos inclusos através de discos diamantados. A face pulpar dos discos foram condicionados com ácido cítrico a $6 \%$ por dois minutos e a face oclusal ficou intacta. A permeabilidade da dentina foi 
medida pela filtração de fluido e expressa como uma condutividade hidráulica (LP). Todas as medições (pré e pós-tratamento) foram realizadas com a mesma pressão. Valores pré-tratamento ou controles foram estabelecidos como 100\%. A condutividade hidráulica pós-tratamento foi expressa como uma porcentagem dos valores pré-tratamento.

Os discos foram divididos em 4 grupos de 15: 1) smear-layer tratada com cloreto de potássio por 2 minutos; 2) tratamento da smear-layer com oxalato de di-potássio neutro por 2 minutos; 3) tratamento da smear-layer com solução de oxalato de potássio monohidrogenado a 3\% por 2 minutos - solução ácida com $\mathrm{pH}=2$; 4) tratamento da smear-layer com oxalato de di-potássio a $30 \%$ por 2 minutos, seguido de oxalato de potássio monohidrogenado a 3\% por 2 minutos. Após cada tratamento a condutividade hidráulica foi redeterminada. Finalmente cada grupo foi condicionado com ácido cítrico a $6 \%$ por 2 minutos para determinar se 0 tratamento tinha modificado a susceptibilidade da smear-layer ao ataque ácido sendo a condutividade hidráulica redeterminada para cada disco. Os resultados foram os seguintes: os discos tratados com cloreto de potássio não tiveram a condutividade alterada e foram susceptíveis ao desafio ácido; os discos tratados com soluções de oxalato tiveram uma redução significante da permeabilidade e foram resistentes ao desafio ácido, um vez que as medições da Lp não mostraram diferenças significativas quando os discos eram condicionados com ácido cítrico por 2 minutos 12 horas ou 24 horas.

PASHLEY; DEPEW ${ }^{46}$, em 1986, avaliaram o efeito da smear layer, do verniz cavitário e do oxalato na permeabilidade dentinária e na 
microinfiltração. Os dentes utilizados neste estudo foram armazenados em solução salina a $4^{\circ} \mathrm{C}$ contendo $0,2 \%$ de azido de sódio para inibir o crescimento bacteriano. As raízes dos dentes foram seccionadas com disco diamantado ao nível da junção cemento/esmalte com remoção da porção coronária da polpa e a coroa remanescente foi fixado a um anteparo de plexiglass ligado a um sistema de medição de permeabilidade similar ao descrito por PASHLEY e GALLOWAY ${ }^{47}$ em 1985. Preparos cavitários de classe I foram confeccionados nos dentes com broca \#558 em alta velocidade e abundante refrigeração. Os preparos receberam os seguintes tratamentos:

Grupo I: Smear layer intacta (sem tratamento)

Grupo II: Condicionamento com ácido cítrico a 6\% por 2 minutos

Grupo III: Condicionamento ácido e aplicação de duas camadas de copalite Grupo IV: Condicionamento ácido e aplicação de solução neutralizada de ácido oxálico a 3\% por 2 minutos

Grupo V: Condicionamento ácido e amálgama

Grupo VI: Condicionamento ácido + duas camadas de copalite + amálgama Grupo VII: Condicionamento ácido + ácido oxálico + amálgama

A permeabilidade dentinária foi medida antes e depois de cada tratamento. As medições para as cavidades restauradas foram feitas 1 hora após. Em relação à permeabilidade dentinária, o grupo I (smear layer) apresentou uma permeabilidade baixa $(6,32 \pm 2,5 \%)$ em comparação ao grupo II (máxima permeabilidade $100 \%$ ). No grupo III o copalite reduziu a permeabilidade em $28 \%$ quando a filtração era realizada da face pulpar para a cavidade e $73 \%$ na direção inversa. O grupo IV (oxalato) reduziu a permeabilidade em $98,25 \%$ e que não foi 
diferente quando a direção da filtração foi modificada. Quando o amálgama foi colocado nas cavidades condicionadas mas sem tratamento, a permeabilidade dentinária foi maior do que os grupos tratados com copalite e oxalato, mas menor do que as cavidades não restauradas e condicionadas (grupo II). A colocação de amálgama reduziu a permeabilidade em 61\%. A colocação de amálgama em cavidades tratadas com oxalato não produziu mudanças quando comparadas àquelas tratadas somente com oxalato sem a colocação de amálgama. Não houve diferenças estatísticas enter os grupos VI e VII, ambos reduziram a permeabilidade em 19 vezes quando comparados com o grupo V. Como os cristais de oxalato de cálcio são insolúveis e resistentes ao condicionamento ácido, a permeabilidade dentinária tendo o oxalato como agente intermediário foi menor do que qualquer outro agente testado.

PASHLEY; KALATHOOR,; BURNHAM $^{52}$, em 1986, estudaram os efeitos do hidróxido de cálcio na permeabilidade dentinária. Os discos de dentina foram obtidos a partir de terceiros molares humanos inclusos e posicionados numa split-chamber para quantificar a permeabilidade dentinária em termos de condutividade hidráulica da dentina. Os discos variavam em espessura de 0,5 a $0,9 \mathrm{~mm}$ e com área exposta de $0,317 \mathrm{~cm}^{2}$. Todos os discos foram condicionados, em ambos os lados, com ácido cítrico a 6\% por 2 minutos para determinação da máxima permeabilidade de cada disco e esta foi estabelecida como $100 \%$. As medições da filtração sempre foram feitas da face pulpar para a face oclusal. Após a determinação da máxima permeabilidade os discos receberam os tratamentos a seguir: 1- aplicação de pasta de hidróxido de cálcio por 2 minutos e 
lavagem por 20 segundos para remoção de resíduos de hidróxido de cálcio com posterior medição da filtração. 2- condicionamento da superfície dentinária com ácido cítrico a $6 \%$ por 2 minutos, para saber se o hidróxido de cálcio proporcionou alguma mudança na susceptibilidade ao condicionamento ácido. 3- confecção de smear layer na face oclusal com broca 69 em alta velocidade e determinação da condutividade hidráulica. 4- aplicação de pasta de hidróxido de cálcio por 2 minutos e determinação da condutividade hidráulica e 5- condicionava-se novamente a superfície dentinária com ácido cítrico a $6 \%$ por 2 minutos para determinar se a modificação da superfície era resistente ao ataque ácido. O tratamento com pasta de hidróxido de cálcio nas superfícies condicionadas com ácido cítrico reduziu a permeabilidade dentinária em $75 \%$ e um novo condicionamento com ácido cítrico restabeleceu a condutividade hidráulica a um nível pouco maior que a condutividade inicial (100\%). A criação da smear layer na superfície condicionada reduziu a permeabilidade dentinária em 99\%. A aplicação de pasta de hidróxido de cálcio em superfície com smear layer reduziu a permeabilidade dentinária de forma significante $(\mathrm{p}<0,025)$ quando comparada com a superfície de smear layer. $O$ último condicionamento com ácido cítrico resultou num retorno da condutividade hidráulica aos níveis dos codicionamentos anteriores. A pasta de hidróxido de cálcio mostrouse efetiva em reduzir a permeabilidade dentinária in vitro, mas oferece pouca proteção ao desafio com ácido cítrico.

MEYRON; TOBIAS; JAKEMAN ${ }^{28}$, em 1987, compararam através de microscopia eletrônica de varredura o efeito de vários agentes na remoção da smear layer tanto in vivo como in vitro. In vivo o EDTA foi o 
condicionador mais potente para remoção de smear layer e ampliação da abertura de túbulos seguido dos outros ácidos, sendo que os agentes de limpeza cavitária tiveram um pequeno efeito. In vitro, todos os ácidos removeram a smear layer de forma similar e provocaram a ampliação da abertura dos túbulos.

PASHLEY et al. ${ }^{65}$, em 1987, através de estudo in vitro, verificou a variabilidade regional da permeabilidade dentinária. As medições foram realizadas qualitativamente pelo uso de corantes, em segmentos de coroa e discos de dentina e quantitativamente pela medição da condutividade hidráulica de discos de dentina. Ambos os espécimes mostraram uma grande variação regional na permeabilidade dentinária. Estudos qualitativos nos segmentos de coroa mostraram maior permeabilidade na região próxima a polpa e menor na região central. Quando estas medições foram feitas nos discos de dentina, oriundos dos segmentos de coroa, a permeabilidade permaneceu heterogênea embora a espessura de dentina fosse uniforme. Este padrão de não uniformidade dos discos indica uma variabilidade regional inerente à permeabilidade dentinária, que não pode ser explicada somente pela espessura de dentina ou pelo comprimento dos túbulos, mas sim pelo maior diâmetro e número dos túbulos em regiões mais próximas aos cornos pulpares. Esta variabilidade foi confirmada com mais segurança pelos testes quantitativos dos discos de dentina através da medição da condutividade hidráulica. Como a permeabilidade pode variar de 3 a 10 vezes em poucos milímetros recomenda-se o uso de uma área de superfície maior possível para compensar estas diferenças regionais. 
ABSI; ADDY; ADAMS ${ }^{1}$, em 1989, analisaram o poder de reprodução de áreas sensíveis e não sensíveis da região cervical dos dentes com a utilização de silicona para moldagem e confecção de réplica com resina epóxica de baixa viscosidade. Este estudo constitui uma alternativa para o exame de dentes sensíveis in situ, sem a extração dentária. Para comprovação da metodologia foram realizados estudos preliminares, o primeiro in vitro com simulação das condições de hipersensibilidade através de raspagem e condicionamento ácido e confecção de réplicas, para permitir comparação direta dos espécimes originais e réplicas; o segundo utilizou dentes extraídos sensíveis e não sensíveis e obtenção das réplicas e o último através da obtenção das réplicas in vivo e após a extração dos dentes, novas réplicas in vitro.

Os resultados deste estudo indicaram que a réplica é na grande maioria das vezes similar ao original tanto in vitro como in vivo, o que possibilita a utilização desta técnica para estudo in vivo da efetividade e mecanismo de ação das drogas utilizadas para sensibilidade dentinária. Consiste de uma técnica não invasiva por prescindir de dentes extraídos.

COOLEY; SANDOVAL ${ }^{12}$, em 1989, avaliaram a efetividade do oxalato na redução da sensibilidade dentinária, tendo como controle a água destilada. Foram utilizadas 28 pessoas com dentes sensíveis em duas regiões diferentes da boca. Um dente foi tratado com água destilada e o outro com oxalato de potássio monohidrogenado. Cada tratamento obteve uma redução na sensibilidade estatisticamente significante após a aplicação dos agentes. A 
sensibilidade dos dentes tratados com água destilada permaneceu aproximadamente constante nos tempos avaliados (1semana, 1 mês e 3 meses), ao passo que a sensibilidade dos dentes tratados com oxalato aumentou progressivamente no mesmo período, tanto que no final de 3 meses não houve diferenças estatísticas com os valores antes do tratamento. Este resultado da água destilada pode ser atribuído ao efeito placebo e fatores psicogênicos que devem ser considerados quando da realização de estudos com dor.

MUZZIN; JOHNSON ${ }^{34}$, em 1989, compararam a utilização de oxalato de di-potássio a $30 \%$ e oxalato monohidrogenado a $3 \%$ na redução da sensibilidade dentinária in vivo. Os tratamentos foram realizados da seguinte forma :

1) Água destilada seguida de oxalato de di-potássio a $30 \%$

2) Água destilada seguida de oxalato monohidrogenado a $3 \%$

3) Água destilada seguida de oxalato de di-potássio a $30 \%$ e oxalato monohidrogenado a $3 \%$

4) Água destilada seguida de água destilada.

Cada paciente, num total de 17 , recebeu os 4 tratamentos em cada dente testado. A sensibilidade ao frio foi estabelecida inicialmente e imediatamente após a aplicação dos agentes e nos tempos de 1, 2 e 4 semanas após o tratamento. Não foram encontradas diferenças na sensibilidade em cada tempo para os quatro tratamentos, entretanto, quando cada tratamento foi comparado separadamente, houve uma redução estatisticamente significante no tratamento 2 nos tempos imediato e 4 semanas e no tratamento 3 , a redução significante ocorreu nos tempos 1 e 2 semanas. Os resultados sugerem a diminuição 
da sensibilidade dentinária seguida da aplicação isolada de oxalato monohidrogenado a 3\% e da aplicação combinada de oxalato de di-potássio a 30\% e oxalato monohidrogenado a $3 \%$.

YOSHIYAMA et al. ${ }^{82}$, em 1989, examinaram áreas de dentina de dentes sensíveis através da utilização de uma ponta diamantada apropriada para remoção de pequenas partes da estrutura dentária sem a extração ou confecção de réplicas. O objetivo principal foi examinar, através de biopsia, as mudanças estruturais da superfície dentinária de dentes com hipersensibilidade em áreas sensíveis e não sensíveis de lesões cervicais. Espécimes de forma cilíndrica de dentina, com $0,8 \mathrm{~mm}$ de diâmetro e 0,5 a $0,8 \mathrm{~mm}$ de comprimento, foram obtidos de áreas sensíveis e de áreas adjacentes não sensíveis, com ponta diamantada cilíndrica oca em alta velocidade e com refrigeração. Quatorze pares de espécimes foram examinados por microscopia eletrônica de varredura e 8 por microradiografia. A observação por MEV das áreas sensíveis mostrou que aproximadamente $75 \%$ dos túbulos dentinários estavam abertos e foi detectada a presença de uma estrutura membranosa nas paredes dos túbulos. Os espécimes das áreas não sensíveis da mesma superfície dentinária, apresentaram apenas $24 \%$ dos túbulos abertos, mais que $70 \%$ dos túbulos estavam obliterados por cristais de forma romba e de diversos tamanhos e no exame dos túbulos longitudinalmente não foi observado a presença de estrutura membranosa. Os resultados mostraram que a hipersensibilidade ocorreu em áreas de dentina exposta onde os túbulos dentinários estavam abertos, e que a oclusão dos túbulos dentinários reduziu a hipersensibilidade. Esta nova técnica de biopsia usada neste estudo permite a obtenção de espécimes de dentina de dentes vitais sem a extração dentária. 
YOSHIYAMA et al. ${ }^{83}$, em 1990, examinaram por microscopia eletrônica de transmissão a ultra-estrutura do lúmen dos túbulos dentinários de regiões sensíveis e não sensíveis de dentes com hipersensibilidade dentinária. Os espécimes foram obtidos pela técnica de biopsia descrita no estudo anterior. Os oito pares de espécimes foram submetidos a microradiografias e mostraram que a maioria dos túbulos dentinários está obliterada por material radiopaco em áreas não sensíveis, mas que nas áreas sensíveis a maioria dos túbulos não está obliterada. As imagens de microscopia eletrônica de transmissão mostraram claramente que nas áreas não sensíveis os túbulos (81\%) estão obliterados por cristais e nas áreas sensíveis a maioria dos túbulos não está obliterada. Os resultados estão de acordo com a teoria hidrodinâmica da dentina sensível que postula que a dentina sensível apresenta túbulos abertos e que a dentina exposta e insensível apresenta túbulos ocluídos.

SENA ${ }^{73}$, em 1990, faz uma revisão dos agentes terapêuticos utilizados para o tratamento da hipersensibilidade dentinária e confirma a importância dos testes laboratoriais no avanço e entendimento do assunto. A preferência de modelos laboratoriais no estudo da hipersensibilidade dentinária deve-se a alguns fatores como, a dificuldade do manejo clínico, problemas na seleção de pacientes, diagnóstico diferencial e a grande resposta do efeito placebo quando se trabalha com dor.

O uso da permeabilidade dentinária no estudo de agentes terapêuticos deve levar em consideração a relação existente entre a hipersensibilidade dentinária com a permeabilidade. O papel da permeabilidade 
dentinária reflete no fato da dentina ser composta por túbulos e permitir a movimentação de fluidos no seu interior, quando estimulada por uma série de fatores (químicos, térmicos, mecânicos, osmóticos e evaporativos), o que levará a uma posterior estimulação de receptores da dor, e é nisto que se baseia a teoria hidrodinâmica.

PASHLEY; ANDRINGA; EICHMILLER ${ }^{51}$, em 1991, compararam a eficiência do oxalato de ferro, oxalato de potássio e condicionador dentinário Tenure na redução da permeabilidade dentinária. Este experimento foi realizado in vitro, com segmentos de coroa e a execução de 4 tratamentos: 1) solução ácida de oxalato de alumínio em ácido nítrico a 2,5\%, 2) solução ácida de oxalato de ferro em ácido nítrico a 2,5\%, 3) Tenure e 4) ácido nítrico a 2,5\%. Antes da aplicação dos agentes, cada espécime passou pela medição da máxima permeabilidade, através da aplicação de EDTA, e da mínima permeabilidade através da simulação da smear layer. Cada agente foi aplicado por 10, 30 e 60 segundos e a condutividade hidráulica foi redeterminada por 5 vezes, apresentando um resultado médio em relação à máxima permeabilidade.

Os resultados indicam que o tratamento da dentina por 10 segundos, para todos os agentes, proporcionou um aumento da permeabilidade dentinária. Aumentando o tempo para 30 segundos houve uma diminuição da permeabilidade dentinária para as soluções à base de oxalato e com 60 segundos de aplicação foram ainda mais efetivas. O tratamento com Tenure, que contém oxalato de alumínio a 2,5\%, não reduziu a permeabilidade dentinária aos níveis dos tratamento com oxalato. Isto pode ser explicado devido a concentração reduzida de 
oxalato e também pela necessidade de um maior tempo de aplicação para que ocorra a formação de sais insolúveis, o que para as soluções à base de oxalato parece ocorrer após 30 segundos de aplicação.

GOODIS; MARSHALL; WHITE ${ }^{16}$, em 1991, determinaram o efeito das soluções de armazenamento e o tempo após a extração na permeabilidade dentinária de dentes humanos. Os dentes utilizados foram divididos em 4 grupos de 10 dentes cada e armazenados em temperatura ambiente, nas seguintes soluções: etanol a $70 \%$, formalina a $10 \%$, água destilada com $0,02 \%$ de timol e solução salina tamponada por fosfato com timol a $0,02 \%$. Os dentes permaneceram nas soluções por um período de 1 semana e somente depois deste período foi confeccionado segmentos de coroa para a realização dos testes de permeabilidade. A água destilada foi utilizada para a movimentação do sistema, evitando os efeitos evaporativos, e consequentemente redução na condutividade hidráulica, que podem ocorrer quando da utilização da solução salina tamponada por fosfato.

Os segmentos de coroa foram colocados nas soluções originais até a realização dos testes, e divididos em dois grupos por tempo de armazenamento. No primeiro grupo a permeabilidade foi medida após 4,6 e 8 dias. No segundo grupo as medições foram realizadas após 1, 2 e 3 semanas de armazenamento. As medições da permeabilidade foram feitas com uma pressão constante de $703 \mathrm{cmH}_{2} \mathrm{O}$ (10p.s.i.).

Os resultados dos espécimes testados após 4, 6 e 8 dias apresentaram grandes diferenças na permeabilidade e variações com o tempo. Os 
espécimes armazenados em solução de formalina apresentou menores variações na permeabilidade e foi a solução de armazenamento mais efetiva seguidas pelo etanol, água destilada e solução salina tamponada por fosfato. Os resultados para os espécimes armazenados por 1, 2 e 3 semanas, também mostraram grandes variações para todas as soluções. Novamente a formalina mostrou-se mais efetiva na limitação de mudanças da permeabilidade em função do tempo.

KERNS et al. ${ }^{23}$, em 1991, avaliaram num estudo longitudinal a oclusão dos túbulos por vários procedimentos clínicos, incluindo planificação radicular e aplicação de oxalato de potássio. Foi desenvolvido um modelo que permite avaliar a superfície dentinária in vivo, pela incorporação de secções de dentina de dentes extraídos em dentaduras de pacientes doadores. Seis segmentos de dentina $(2 \mathrm{~mm} \times 3 \mathrm{~mm})$ foram obtidos de dentes extraídos próximo ao limite cemento/esmalte. Os segmentos foram tratados da seguinte maneira: 1) dois segmentos foram planificados e não receberam tratamento algum, 2) dois segmentos foram tratados com oxalato de potássio e 3) os segmentos restantes foram tratados com EDTA, servindo como controle. Metade dos segmentos tratados foram incorporados em próteses parciais removíveis dos próprios pacientes que extraíram os dentes. E os segmentos restantes funcionaram como controle.

Os resultados indicaram que as amostras incorporadas nas próteses tiveram uma aparência diferente dos controles quando examinados em microscopia eletrônica de varredura. A avaliação após uma semana dos espécimes que foram planificados e não receberam tratamento mostrou dissolução parcial da smear layer e túbulos dentinários abertos. Os espécimes tratados com oxalato 
apresentaram pouco cristais remanescentes no final de 7 dias. Nos espécimes tratados com EDTA ao final de uma semana não houve mudanças significantes, mas apenas poucos túbulos permaneceram abertos ao final de 28 dias, e isto pode ser responsável pela redução espontânea da sensibilidade dentinária (deposição de cristais oriundos da saliva). Os autores concluem que a criação de smear layer ou aplicação de oxalato para oclusão dos túbulos e redução da sensibilidade dentinária tem um período curto de duração frente aos estímulos do meio bucal.

SIMPSON et al. ${ }^{75}$, em 1992, avaliaram o efeito da aplicação de oxalato de alumínio na permeabilidade da dentina de dentes humanos extraídos. Foram utilizados segmentos de coroa para medição da condutividade hidráulica. Estas medições foram feitas após a aplicação de ácido fosfórico a 37\% por 15 segundos (máxima permeabilidade), após a simulação da smear layer e após a aplicação dos agentes no período de $15 \mathrm{~min}$. e $24 \mathrm{~h}$. As soluções de oxalato de alumínio utilizadas variavam em pH de 0,5 a 2,5, num total de cinco soluções, e foram aplicadas por um minuto. A pressão utilizada para as medições da condutividade hidráulica foi de $703 \mathrm{cmH}_{2} \mathrm{O}$. As soluções com pH 0,5 a 1,5 removeram a maior parte da smear layer mas obliteraram os túbulos com depósitos cristalinos que reduziram a permeabilidade dentinária. As soluções com pH 2 e 2,5 aumentaram a permeabilidade dentinária. Todas as soluções aumentaram a permeabilidade dentinária quando medidas após $24 \mathrm{~h}$ de armazenamento, especialmente para as soluções com pH 2 e 2,5. 
PASHLEY $^{43}$, em 1992, numa revisão de literatura sobre a permeabilidade dentinária e a sensibilidade dentinária, afirmou que a teoria hidrodinâmica da dentina sensível é baseada na premissa de que a dentina sensível é permeável em toda extensão dos túbulos. Esta condição permite a difusão de produtos bacterianos pela dentina até alcançar a polpa, causando irritação dos tecidos pulpares. Entretanto, a movimentação do fluido dentinário para fora é lenta e permite a passagem de substâncias exógenas pelos túbulos abertos. O autor conclui que o balanço entre a difusão de substâncias exógenas, seja bacterianas ou de agentes dessensibilizantes, e a limpeza proporcionada pelo fluido dentinário merece mais estudo. Acrescenta que qualquer tratamento que reduza a permeabilidade dentinária deverá diminuir a sensibilidade dentinária, e este entendimento do papel da permeabilidade dentinária no processo de hipersensibilidade faz com que métodos simples de estudo in vitro examinem o potencial de novos agentes terapêuticos na oclusão dos túbulos dentinários.

GOODIS et al. ${ }^{17}$, em 1993, avaliaram o efeito do tempo de armazenamento e da solução empregada para armazenagem, sobre a permeabilidade e resistência adesiva à dentina em diferentes períodos de tempo (8 dias, 15 dias e 6 meses). Os dentes foram armazenados imediatamente após a extração em uma das cinco soluções avaliadas (etanol a $70 \%$, formalina a $10 \%$, água destilada, água destilada com timol ou solução salina tamponada por fosfato com timol).

A permeabilidade dentinária variou com o tipo de solução e a duração do armazenamento, aumentando progressivamente a partir da solução de 
formalina e etanol até as soluções aquosas. O armazenamento na solução salina resultou num decréscimo significativamente elevado na permeabilidade em tempos prolongados, sugerindo alterações na dentina. Os autores concluíram que a permeabilidade e a resistência adesiva podem ser afetadas pelas condições de armazenamento dos espécimes e que as soluções aquosas foram as que menores interferências apresentaram sobre as duas condições estudadas.

KNIGHT et al. ${ }^{24}$, em 1993, examinaram através de microscopia eletrônica de varredura o efeito de obliteração dos túbulos dentinários através da realização de procedimentos mecânicos e químicos. Os espécimes de dentina, contendo túbulos abertos e cortados transversalmente, foram divididos em dois grupos, um experimental, e outro controle. Os tratamentos mecânicos foram realizados pela instrumentação contínua por 20 segundos de instrumentos de diferentes composições, metálicas, plásticas, dentre outros. Os tratamentos químicos incluem: resina composta, fluoretos, oxalatos de potássio e férrico, glicerina e nitrato de potássio.

Os resultados revelaram que entre os agentes mecânicos, a cureta afiada apresentou uma obliteração mais consistente e completa dos túbulos. E os instrumentos de inserção plástica não tiveram efeitos oclusivos sobre os túbulos. Entre os tratamentos químicos, a resina composta fotopolimerizável promoveu uma obliteração completa dos túbulos, o oxalato de potássio a $3 \%$ obliterou os túbulos com um grande número de pequenos cristais espalhados na superfície dentinária, mas não foi efetivo na obliteração dos túbulos pois a maioria 
dos cristais desapareceram após um spray de água. Os agentes a base de flúor e glicerina não apresentaram nenhum efeito oclusivo sobre os túbulos.

MATTHEWS; SHOWMAN; PASHLEY ${ }^{26}$, em 1993, mediram os efeitos evaporativos, in vitro, em condições espontâneas e com o uso de seringa de ar. O objetivo do estudo foi: 1) medir a proporção de evaporação espontânea de água da dentina na presença e ausência de smear layer, 2) medir a proporção de evaporação de água da dentina quando da aplicação direta de jatos de ar aquecidos na seringa tríplice ou uma peça de mão de alta rotação à distância de 1 a 10cm e 3) medir a proporção de evaporação de água da dentina induzidas por jatos de ar à temperatura de 10 a $50^{\circ} \mathrm{C}$, a $1 \mathrm{~cm}$ da superfície de dentina. Os jatos de ar induziram um aumento de 15 a 30 vezes na perda de água por evaporação, a qual variou inversamente com a distância do jato ao dente e diretamente com a temperatura do ar.

PASHLEY; MATTHEWS ${ }^{49}$, em 1993, mediram o efeito da presença ou ausência de smear layer na difusão de substâncias pela dentina, in vitro, através da aplicação ou não aplicação de pressão pulpar fisiológica. Isto foi realizado para determinar como a movimentação de fluidos de dentro para fora da dentina pode modificar a proporção de difusão de substâncias potencialmente irritantes para o interior dos túbulos dentinários. Através da utilização de discos de dentina posicionados numa câmara apropriada, a difusão de ${ }^{125}$ | foi medida nas seguinte condições: 1) presença de smear layer sem a aplicação de pressão, 2) presença de smear layer com aplicação de pressão de $15 \mathrm{cmH}_{2} \mathrm{O}$, 3) remoção de 
smear layer sem aplicação de pressão e 4) remoção de smear layer com pressão de $15 \mathrm{cmH}_{2} \mathrm{O}$.

Cada espécime foi estudado em 2 ou 3 espessuras, pelo lixamento da face oclusal com papel de abrasividade 320. Os resultados mostraram que quando a smear layer está presente na aplicação de $15 \mathrm{cmH}_{2} \mathrm{O}$ de pressão, houve uma redução de 10 a $20 \%$ do fluxo de iodo. Quando a smear layer foi removida e a pressão aplicada, a redução da difusão do iodo foi para $60 \%$. As medições do fluxo de iodo mostraram-se dependentes da espessura e da condutividade hidráulica. Os resultados demonstram a importância do balanceamento entre a difusão de substâncias e a pressão aplicada para movimentação de fluidos para fora na proporção de permeação de solutos exógenos.

SASAZAKI; OKUDA ${ }^{72}$, em 1994, examinaram a exsudação de fluido dentinário após o preparo da superfície dentinária em função do tempo. Estas observações foram feitas pelo uso da técnica de réplica de precisão. As superfícies dentinárias foram observadas da seguinte forma: 1) a superfície oclusal dos dentes foi reduzida com pontas diamantadas em alta rotação e brocas em baixa velocidade até a completa planificação. As superfícies foram lavadas abundantemente, secas e foi obtido uma réplica para observação em microscopia eletrônica de varredura. As superfícies dentinárias dos dentes foram desgastadas novamente e examinadas da mesma forma, 2) realização de cavidades MO e MOD em pré-molares e molares e confecção de réplicas. As cavidades foram restauradas 
provisoriamente com inlays e após 14 dias foram feitas novas moldagens para proceder um novo exame das superfícies dentinárias e das paredes cavitárias.

Para os dentes recém-extraídos, a quantidade de exsudação de fluidos diminuiu com o tempo, com pouco exsudato após 60 minutos. No caso realizado in vivo a exsudação de fluidos internos foi também observada na superfície dentinária após 14 dias.

GOODIS et al. ${ }^{18}$, em 1994, através de um estudo in vitro, avaliaram o efeito da aplicação do laser na dentina através da medição da condutividade hidráulica. A técnica foi similar a utilizada por GOODIS, MARSHALL e WHITE $^{16}$ em 1991, mas o líquido do sistema foi o soro de feto bovino (10, 25 e 100\%). A permeabilidade foi medida imediatamente após a exposição do laser e 72 horas depois. $\mathrm{O}$ tratamento com laser reduziu a permeabilidade imediatamente para todas as soluções, com valores menores para as soluções com 25 e $100 \%$ de soro fetal bovino. Os autores concluíram que o tratamento com laser reduz a permeabilidade dentinária transitoriamente pela coagulação das proteínas contidas no soro, sem alteração da superfície dentinária.

SHONO et al. ${ }^{74}$, em 1994, avaliaram uma nova formulação de oxalato de potássio e oxalato de alumínio na redução da permeabilidade dentinária in vitro, e na alteração da superfície dentinária por microscopia eletrônica de varredura. As medições da permeabilidade foram executadas em segmentos de coroa antes e após a aplicação de uma solução salina (controle) e da solução experimental (oxalato de di-potássio a 5\% + oxalato de alumínio a 5\% em ácido 
nítrico a $2 \%, \mathrm{pH} 2$ ) por 10,30 e 60 segundos. O tratamento da smear layer com a solução de oxalato produziu uma obliteração significante dos túbulos. O tratamento da dentina condicionada com solução de oxalato formou precipitados de tamanhos menores que os anteriores. O tamanho dos cristais precipitados e a espessura da camada de precipitado aumentou com o tempo do tratamento. Os resultados indicaram que a nova formulação de oxalato obstrui significantemente os túbulos dentinários , podendo ser utilizado como um agente dessensibilizador dentinário ou um forrador cavitário.

PRATI ${ }^{69}$, em 1994, numa revisão de literatura, relatou o papel da permeabilidade dentinária sobre a resistência adesiva dos sistemas adesivos e sua relação com a morfologia dentinária. A dentina profunda é mais permeável que a dentina superficial. A desmineralização da superfície dentinária com condicionadores ácidos aumenta a permeabilidade significantemente. Vários primers deixam a smear layer aparentemente intacta, mas aumentam em grande escala a filtração de fluidos pela dentina, sugerindo modificações na smear layer. As primeiras gerações de adesivos dentinários mostravam-se extremamente sensíveis à permeabilidade e umidade dentinária, ao passo que os sistemas adesivos mais recentes não são influenciados pela umidade da dentina. De acordo com a equação de Poiseuille-Hagen, pequenas mudanças no diâmetro funcional dos túbulos podem alterar a permeabilidade dentinária em grande escala. Os materiais restauradores são capazes de reduzir a permeabilidade dentinária independente da localização do preparo. O autor conclui que a importância do estudo da permeabilidade dentinária 
deve-se ao fato de que a avaliação da movimentação do fluido ajuda a elucidar os mecanismos responsáveis pela dor, falhas de restaurações e danos pulpares.

PRATI; MONGIORGI; FERRIERI ${ }^{70}$, em 1994, avaliaram o efeito de vários cremes dentais dessensibilizantes através da medição da permeabilidade dentinária in vitro antes e após o tratamento tópico com as pastas. Os dentes utilizados foram reduzidos a segmentos de coroa e a câmara pulpar foi preenchida com água deionizada, e conectada a uma pressão de trabalho de 1p.s.i. $\left(70,3 \mathrm{cmH}_{2} \mathrm{O}\right)$. Os cremes dentais testados foram : Sensodyne e Sensodyne F, Oral B para dentes sensíveis, Neo Mentadent $P$ (controle) e um creme dental experimental contendo oxalato de potássio. Antes da aplicação dos cremes dentais a superfície dentinária foi condicionada com ácido fosfórico a 37\% por 2 min. para remover a smear layer e simular a máxima permeabilidade (100\%). Os cremes dentais foram aplicados por 3min. e a permeabilidade dentinária foi redeterminada. Um novo condicionamento com ácido fosfórico foi realizado e a permeabilidade foi avaliada novamente. $\mathrm{O}$ creme dental contendo oxalato de potássio provocou a maior redução na permeabilidade dentinária (40\%). Após o desafio ácido somente esse dentifrício permaneceu com a permeabilidade reduzida, indicando que os outros dentifrícios foram sensíveis ao condicionamento ácido.

MONGIORGI; PRATI ${ }^{32}$, em 1994, avaliaram o efeito de soluções de oxalato na condutividade hidráulica da dentina in vitro. Os espécimes $(n=25)$ foram divididos em 5 grupos e a superfície dentinária recebeu o tratamento das soluções experimentais e controle por 2 minutos. Antes do tratamento, todos os 
espécimes foram condicionados com ácido fosfórico a 37\% por 2 minutos, para remover a smear layer e simular a máxima permeabilidade (100\%). O tratamento com solução de cloreto de sódio a $0,9 \%$ (controle negativo) não teve efeito na permeabilidade dentinária. O tratamento com ponta diamantada (controle positivo), para criar smear layer, reduziu a permeabilidade de 100\% para 2,9\%. Os espécimes tratados com Dentine Protect (ácido oxálico) reduziu a permeabilidade para 3,9\% do valor máximo. Todas as soluções de oxalato reduziram a permeabilidade a valores tão baixos quanto aos da smear layer $(3,5 \%$ e $2,2 \%)$ e não houve diferenças estatísticas entre os tratamentos.

KOUTSI et al. ${ }^{25}$, em 1994, mediram a permeabilidade dentinária em molares decíduos e em pré-molares permanentes a várias distâncias da polpa, através da redução da superfície dentinária, e correlacionaram os dados de permeabilidade com densidade tubular e diâmetro dos túbulos através de microscopia eletrônica de varredura. Os resultados mostraram que a permeabilidade de todos os dentes aumentou com a diminuição da espessura de dentina e a remoção da smear layer resultou num aumento significante da permeabilidade. Entretanto, a permeabilidade da dentina em pré-molares foi significativamente maior do que em molares decíduos, e isto pode ser explicado devido ao maior número e diâmetro dos túbulos presentes nos pré-molares.

CAMPS et al. ${ }^{8}$, em 1994, avaliaram o efeito da criopreservação de dentes humanos na permeabilidade dentinária. Os dentes foram divididos em dois grupos de 180 dentes cada. Num grupo, os dentes foram 
armazenados em solução salina tamponada por fosfato a $4^{\circ} \mathrm{C}$ e, no outro, os dentes foram criopreservados de acordo com o protocolo do Departamento de Criobiologia do Centro Regional de Transfusão Sanguínea (Marseille, França). A condutividade hidráulica da dentina foi medida de acordo com o método descrito por OUTHWAITE; LIVINGSTON; PASHLEY ${ }^{36}$. Os resultados indicaram que os dentes criopreservados apresentaram uma condutividade hidráulica de $8,97 \times 10^{-3} \pm 4,21 \times 10^{-3}$ e foi ligeiramente maior do que a condutividade hidráulica dos dentes armazenados a $4^{\circ} \mathrm{C}, 8,03 \times 10^{-3} \pm 3,87 \times 10^{-3}$. Não houve diferenças estatísticas entre os grupos e no exame por microscopia eletrônica de varredura os dentes criopreservados não apresentaram rachaduras.

CAMPS et al. ${ }^{9}$, em 1995, compararam o efeito de diferentes concentrações de ácido maleico e tempo de aplicação na permeabilidade dentinária. Cento e trinta dentes hígidos foram divididos em 5 grupos. Grupo 1 - Smear layer não tratada $(\mathrm{n}=10)$. Grupo 2 - Tratamento da smear layer com $0,1 \mathrm{M}$ de solução aquosa de ácido maleico por 15, 30 e 60 segundos $(n=30)$. Grupo 3 - Tratamento da smear layer com $0,25 \mathrm{M}$ de solução aquosa de ácido maleico por 15, 30 e 60 segundos (n=30). Grupo 4 - Remoção da smear layer com 0,5M de solução aquosa de ácido maleico por 15, 30 e 60 segundos $(n=30)$. Grupo 5 - Tratamento da smear layer com condicionador do Scotchbond Multi-Purpouse (SBMP) - concentração de 0,86M de ácido maleico por 15, 30 e 60 segundos $(n=30)$.

A permeabilidade dentinária foi determinada como condutividade hidráulica e os resultados indicaram que as soluções de ácido maleico a 0,25 e 0,5M foram mais efetivas em aumentar a permeabilidade dentinária do que 
o condicionador do SBMP e a solução de $0,1 \mathrm{M}$ de ácido maleico, pois a máxima permeabilidade foi alcançada em pouco tempo (15s). Após 60 segundos de aplicação todas as soluções mostraram-se efetivas no aumento da permeabilidade dentinária

YAMAMOTO et al. $^{80}$, em 1995 , examinaram a posição dos cristais precipitados após o tratamento com oxalato de potássio em dentina exposta de cães in vivo, e, também foi examinado a estabilidade dos cristais pelo exame da superfície tratada e dos túbulos após uma semana de exposição ao ambiente oral. A dentina foi exposta com a utilização de brocas e a superfície tratada com oxalato de di-potássio a $30 \%$ seguida de oxalato monohidrogenado a $3 \%$ após 0 condicionamento ácido. Após o tratamento com o oxalato numerosos cristais foram encontrados tanto na superfície como no interior dos túbulos $(100 \mu \mathrm{m})$. A densidade dos cristais na superfície dentinária e no interior dos túbulos foi diminuindo após 1 semana de exposição à cavidade oral. A dentina estava coberta com smear layer mas muitos dos túbulos dentinários apresentavam-se abertos e ampliados e os cristais foram encontrados nas porções mais profundas dos túbulos.

Os resultados indicam que a precipitação de cristais de oxalato in vivo ocorre não somente na superfície dentinária mas também no interior dos túbulos e que a precipitação de cristais no interior dos túbulos ocorreu somente quando a smear layer foi removida por ácidos.

SUGE et al. ${ }^{77}$, em 1995, estudaram a efetividade da obliteração de túbulos dentinários em saliva sintética avaliando o método de 
precipitação de cálcio/fosfato em condições similares ao ambiente bucal. Discos de dentina tratados pelo método de precipitação de cálcio/fosfato e discos tratados com oxalato de potássio, fluoreto de sódio e cloreto de estrôncio foram imersos em saliva sintética. O tratamento pelo método de precipitação de cálcio/fosfato reduziu a permeabilidade dentinária para $6 \%$. Quando os discos foram imersos em saliva, a permeabilidade dentinária permaneceu baixa, mesmo após 7 dias de imersão. 0 tratamento com oxalato de potássio também reduziu a permeabilidade dentinária para $8 \%$. Entretanto esta permeabilidade aumentou com o tempo de imersão em saliva para $39 \%$ ao final de 7 dias. Isto pode ser explicado pois quando o oxalato de cálcio é imerso na saliva sintética, aparece uma grande quantidade de íons oxalato, indicando dissolução do oxalato de cálcio e desta forma, aumentando a permeabilidade dentinária. Em contraste, os íons cálcio e fosfato diminuem quando o produto formado pelo método de precipitação é imerso em saliva. Os autores concluíram que o método de precipitação de cálcio/fosfato tem um efeito contínuo de redução na permeabilidade dentinária no ambiente bucal.

CIUCCHI et al. ${ }^{11}$, em 1995, observaram a dinâmica da movimentação de fluido da dentina humana in vivo. Cavidades de classe $V$ foram preparadas em pré-molares humanos com dimensões que permitiam a adaptação de uma câmara no seu interior, a qual estava adaptada a um circuito hidráulico, possibilitando o ajuste de pressão e a medição da movimentação do fluido pela dentina. Este dispositivo (Flodec) apresenta receptores fotosensíveis que detectam mínimos deslocamentos de líquidos $(5 \mu \mathrm{m})$, e é acoplado a um microcomputador para armazenamento dos dados. $\mathrm{Na}$ ausência de pressão exógena todas as 
cavidades exibiram uma movimentação de fluido para fora em proporção de $0,36 \mu l$ $\min ^{-1} \mathrm{~cm}^{-2}$. Quando a pressão externa era aplicada à cavidade, a movimentação do fluido decrescia. A pressão externa que provocou o equilíbrio de movimentação do fluido foi considerada como sendo a mesma pressão interna da polpa. O valor médio foi de $14,1 \mathrm{cmH}_{2} \mathrm{O}$. Os autores concluíram que este método simples permite a medição da movimentação do fluido dentinário, a medição da condutividade hidráulica da dentina e estimação da pressão do tecido pulpar.

ESTRELA et al. ${ }^{13}$, em 1996, realizaram um estudo com 160 dentes (caninos e pré-molares) portadores de hipersensibilidade dentinária observada após tratamento periodontal. Cada produto testado foi aplicado em 20 dentes com graus variados de hipersensibilidade. As avaliações foram executadas no período de $7,15,30$ e 60 dias através da análise da redução da hipersensibilidade com estímulos táteis (teste do explorador) e térmico (teste da água fria e do jato de ar). No grupo 1 foi utilizada a água destilada como agente placebo, por meio da aplicação por $2 \mathrm{~min}$. com bolinhas de algodão. No grupo 2 o fluoreto de sódio foi aplicado por $5 \mathrm{~min}$., sendo que no primeiro minuto fez-se brunidura com o auxílio de uma taça de borracha. No grupo 3 aplicou-se a pasta de hidróxido de cálcio com água destilada, seguindo o mesmo critério do grupo 2. Nos grupos 4 e 5 foram aplicados o Oxa-Gel e o Duraphat, seguindo-se as instruções dos fabricantes. Nos grupos 6, 7, e 8 aplicaram-se os sistemas adesivos Scothbond Multi-uso Plus, Optibond e Multibond Alpha, seguindo-se as recomendações dos fabricantes e empregando o ácido fosfórico a 37\% por 15 segundos para o condicionamento. Com exceção dos sistema adesivos que foram utilizados somente 
uma vez, os demais produtos foram novamente aplicados a cada período de observação.

Os resultados indicaram que o hidróxido de cálcio e o fluoreto de sódio a $2 \%$ apresentaram os menores valores na redução de dor póstratamento, para os 3 níveis de sensibilidade. O Duraphat e o sistema adesivo Multibond Alpha mostraram valores intermediários em todos os níveis de sensibilidade. Para o nível 1 de sensibilidade o sistema adesivo Optibond e o OxaGel demonstraram os melhores valores de redução de dor, $88,8 \%$ e $87,5 \%$ respectivamente. Para os níveis 2 e 3 o Oxa-Gel e o sistema adesivo Scothbond Multi-uso Plus mostraram os melhores resultados, $87,5 \%$ e $75 \%, 75 \%$ e $75 \%$, respectivamente. Pode-se notar a ocorrência de baixa redução de dor imediatamente à aplicação dos sistemas adesivos, para os 3 níveis, melhorando expressivamente aos 30 dias. No grupo controle, mesmo empregando um agente placebo (água destilada), verificou-se que para o nível 1 de sensibilidade aos 60 dias a redução de dor pós-tratamento chega a $40 \%$.

YOSHIYAMA; SUGE; EBISU ${ }^{81}$, em 1996, determinaram a existência de diferenças na distribuição de estruturas de forma tubular em áreas de dentes sensíveis e não sensíveis. Os espécimes foram obtidos por biopsia conforme proposto por YOSHIYAMA et al. $^{82}$ em 1989. Dez pares de biópsias foram submetidas ao tratamento com colagenase- $\mathrm{HCl}$ para eliminação parcial da superfície e permitir a visualização das estruturas na sub-superfície. Metade dos espécimes foi incluído em resina para facilitar o seccionamento longitudinal, e a outra metade foi preparada para observação em microscopia eletrônica de varredura e 
espectroscopia de energia dispersiva. As biópsias de regiões hipersensíveis apresentaram uma estrutura oca e tubular no interior dos túbulos em $75,8 \%$ dos túbulos. Nas biópsias de áreas não sensíveis no mesmo dente, essas estruturas foram vistas somente em $20,4 \%$ dos túbulos. Os autores afirmaram que a estrutura tubular encontrada nas regiões sensíveis são responsáveis pela manutenção da abertura dos túbulos e que a mesma impede a oclusão espontânea dos túbulos, mantendo desta forma a sensibilidade dentinária.

PASHLEY et al. ${ }^{66}$, em 1996, avaliaram a magnitude e direção da movimentação do fluido pela dentina in vitro, através de estímulos utilizados na clínica para detectar a sensibilidade dentinária, e então, transformandoos em valores equivalentes que permite uma comparação entre os estímulos. A equivalência dos estímulos hidrodinâmicos pode ser conseguida pela medição da movimentação do fluido e sua relação com a condutividade hidráulica de cada espécime. Desta forma, consegue-se um denominador comum (pressão hidrostática), que é responsável pela movimentação do fluido em todas as condições. As medições da condutividade hidráulica foram feitas em segmentos de coroa, através de um dispositivo capaz de detectar pequenas alterações $(5 \mu \mathrm{m})$ na movimentação do fluido - Flodec. Os estímulos hidrodinâmicos utilizados foram: jatos de ar, calor, frio, estímulo tátil e osmótico. Em dentina superficial condicionada a movimentação do fluido ocorreu em ordem decrescente para os estímulos: calor, frio, jatos de ar, osmótico e tátil. Quando houve a equivalência dos valores a escala continuou a mesma. Os autores acrescentaram que esta abordagem de comparar estímulos hidrodinâmicos deveria ser verificada in vivo. 
CAMPS et al. ${ }^{10}$, em 1997, avaliaram o efeito do emprego de baixa e alta pressão nos estudos in vitro para determinação da condutância hidráulica da dentina humana. Empregando o sistema descrito por CAMPS et al. ${ }^{8}$ em 1994, realizaram testes variando a pressão de 1,3kPa até 53,3kPa e acompanharam a dinâmica de filtração de água através dos discos de dentina por períodos de 10 a 180 minutos. Os resultados demonstraram que o volume total de fluido filtrado aumentou proporcionalmente com o tempo e a pressão. Para pressões de 13,3, 26,6 e 40kPa, a filtração e condutância hidráulica diminuíram com o passar do tempo, enquanto que para pressões de 1,3 e 53,3kPa esse fenômeno não foi observado. Enquanto o uso de baixa pressão (1,3kPa) parece não alterar a dinâmica da filtração através da dentina, pressões gradativamente maiores podem produzir deslocamentos de substâncias presentes dentro dos túbulos, causando alterações nas medidas da condutância hidráulica com o passar do tempo. Os autores recomendam cautela na interpretação de resultados obtidos em condições experimentais que fogem da realidade fisiológica.

MORDAN; BARBER; GILLAM ${ }^{33}$, em 1997, desenvolveram uma metodologia que permite a utilização de substâncias experimentais e controle num mesmo disco de dentina. Isto permite uma forma melhor de comprovar in vitro a ação de agentes utilizados para sensibilidade dentinária. Os discos de dentina receberam o seguinte tratamento: 1) dois discos não receberam tratamento algum, 2) dois discos foram tratados com ultra-som em água destilada para remover 
partículas e 3) dois discos foram tratados com ultra-som e ácido cítrico a 6\% por 2 minutos. Os agentes testados foram Sensodyne Sealant e Butler Protect.

Os discos que não receberam tratamento apresentaram uma aparência típica de smear layer quando examinados por microscopia eletrônica de varredura. O ultra-som com água destilada não removeu completamente os fragmentos da superfície dentinária. Após o condicionamento ácido a smear layer foi removida e os túbulos ficaram claramente visíveis. Depois da aplicação dos agentes foi notado um nível variável de deposição de cristais na superfície dentinária. Os autores concluíram que o disco de dentina constitui um método bom e confiável para examinar e testar o potencial dos agentes dessensibilizantes.

GILLAM; MORDAN ; NEWMAN ${ }^{15}$, em 1997, através de uma revisão de literatura, avaliaram os agentes dessensibilizantes utilizados in vitro, as técnicas usadas para caracterizar seus efeitos na superfície dentinária preparada e a capacidade desses agentes em reduzir a permeabilidade através da obliteração dos túbulos. Os autores concluíram que o modelo de disco de dentina que determina características superficiais e redução na permeabilidade dentinária por oclusão dos túbulos consiste em um método útil para examinar o potencial dos agentes usados para sensibilidade dentinária. E, acrescentam que a extrapolação clínica das alterações observadas in vitro devem ser feitas com cuidado.

JAIN et al. ${ }^{21}$, em 1997, avaliaram o efeito de 4 agentes dessensibilizantes dentinários na oclusão dos túbulos, modificações na superfície dentinária e o efeito da saliva e escovação. Os espécimes foram divididos em 5 
grupos de 10 dentes cada. No grupo 1 não foi feito tratamento algum (controle). No grupo 2 a superfície dentinária foi tratada com Sensodyne Dentin Desensitizer (solução de oxalato de ferro a $6 \%$ ). No grupo 3 foi utilizado Therma -Trol Desensitizer gel (solução de oxalato de potássio). O grupo 4 foi tratado com Gluma Dentin Desensitizer (solução aquosa de glutaraldeído e HEMA) e no grupo 5 os espécimes foram tratados com All Bond DS.

Cinco dentes de cada grupo foram examinados por microscopia eletrônica de varredura e submetidos a análise de dispersão de raios $\mathrm{X}$. Os outros cinco discos foram imersos em saliva por 24 horas, submetidos a escovação e examinados através de microscopia eletrônica de varredura. Os resultados mostraram que o Sensodyne exibiu maior quantidade de oclusão de túbulos entre os dentes que não receberam escovação, seguidos de Therma-Trol, Gluma e All Bond. A escovação promoveu um aumento da oclusão dos túbulos em todos os casos, exceto para o Sensodyne.

ZHANG et al. ${ }^{84}$, em 1998, avaliaram a eficácia de uma emulsão de resina no tratamento da sensibilidade dentinária, através da diminuição da permeabilidade dentinária in vitro. Os segmentos de coroa foram divididos em dois grupos: no primeiro, a superfície dentinária foi condicionada com ácidos para simular a abertura dos túbulos da hipersensibilidade dentinária e no segundo, a superfície dentinária foi polida com uma pasta de hidroxiapatita e ultra-som e apresentou-se livre de smear layer, mas sem sofrer desmineralização. A condutividade hidráulica de cada espécime foi medida com o auxílio de um dispositivo (Flodec), que permite medições precisas com pressão reduzida 
(fisiológica). Após o tratamento com o agente dessensibilizador, a condutividade hidráulica foi redeterminada aos 5 minutos, 1 dia , 1 semana e 1 mês. Entre os intervalos de tempo, os espécimes foram armazenados numa solução tamponada para simular os efeitos solubilizantes da saliva. Os resultados mostraram que uma única aplicação da resina promoveu reduções grandes e imediatas na permeabilidade dentinária em ambos os grupos. Nos espécimes condicionados com ácido a permeabilidade dentinária retornou aos valores controles no período de 7 dias, enquanto que nos espécimes não condicionados a permeabilidade permaneceu baixa após os 30 dias. Este simples tratamento de oclusão dos túbulos apresenta uma redução da permeabilidade dentinária e permite o desenvolvimento de uma dessensibilização natural. 


\section{PROPOSIÇÃo}

O objetivo deste estudo, in vitro, é o de testar através da medição da condutibilidade hidráulica da dentina, a influência do tempo pósaplicação dos agentes anti-hiperestésicos na permeabilidade de discos de dentina, tendo como variáveis:

1) Produto comercial à base de oxalato da potássio (OXAGEL),

2) Dois agentes experimentais à base de oxalato de potássio,

3) Dois controles, um para o material e outro para o sistema de filtração,

4) Intervalos de tempo pós-aplicação (imediato, 5 minutos, 15 minutos e 30 minutos). 


\section{MATERIAL E MÉTODOS}

\section{Obtenção e seleção dos dentes:}

Neste estudo foram utilizados cinquenta terceiros molares humanos, recém-extraídos, hígidos, de preferência não irrompidos na cavidade bucal os quais, após a extração, passavam por um processo de limpeza e remoção de remanescentes do ligamento periodontal e tecidos moles circunjacentes sendo armazenados em solução de $100 \mathrm{mM}$ de azido de sódio, $50 \mathrm{mM}$ de benzamidine $\mathrm{HCl}$ e 10mM de $\mathrm{N}$-etil maleimide, diluída em água destilada na proporção de 1:20, para prevenir contaminação bacteriana até a obtenção dos espécimes. O período de armazenamento até o momento de obtenção dos espécimes não foi superior a seis meses.

\section{Obtenção dos espécimes:}

Os dentes foram fixados a um dispositivo de resina epóxica com cera pegajosa, adaptados a uma máquina de corte (Labcut 1010 EXTEC $^{1}$ ) e seccionados com disco de diamante (XL 12205-EXTEC ${ }^{1}$ ), com 101,6mm de diâmetro e 0,3mm de espessura, em baixa velocidade (300 rpm) e com abundante

\footnotetext{
${ }^{1}$ EXCTEC - DIVISION EXCEL TECHNOLOGIES INC., ENFIELD, CONNECTICUT, E.U.A.
} 
refrigeração (Figuras 1 e 2). Os espécimes foram obtidos através do seccionamento transversal das coroas dentárias acima da projeção dos cornos pulpares e abaixo da junção amelodentinária oclusal, de forma a constituírem discos com a região central composta exclusivamente por dentina (Figuras 3, 4 e 5). Assim, obtiveramse discos de dentina, envolvidos por esmalte periférico com espessuras médias de $0,92 \pm 0,08 \mathrm{~mm}$, aferidas com um paquímetro digital ${ }^{2}$ (Figura 6).

Após a obtenção dos espécimes, a presença do esmalte e de remanescentes pulpares foram avaliadas com o auxílio de lupa estereoscópica ${ }^{3}$ com 30X de aumento. Caso houvesse algum resquício desses tecidos, procedia-se o desgaste das superfícies com a utilização de lixa de carbureto de silício de granulação $600^{4}$, adaptada numa politriz ${ }^{5}$, respeitando-se o limite das espessuras citadas anteriormente. Lixas de carbureto de silício de granulação $1500^{4}$ foram utilizadas para acabamento dos espécimes, deixando as superfícies de dentina lisas e uniformes. Cada dente dava origem a apenas um espécime.

\section{Medição da condutividade hidráulica}

\subsection{Dispositivo:}

O dispositivo utilizado para a realização das medições da condutividade hidráulica consiste de um aparato complexo, formado por várias partes que se interligam formando um único sistema (Figura 7). É composto por:

\footnotetext{
MITUTOYO CORPORATION, TÓQUIO, JAPÃO

${ }^{3}$ MEIJI TECHNO Co. Ltda., TÓQUIO, JAPÃO

${ }^{4} 3 \mathrm{M}$ do BRASIL, SUMARÉ, SÃO PAULO, BRASIL

${ }^{5}$ PANAMBRA INDUSTRIAL E TÉCNICA S.A., SÃO PAULO, BRASIL
} 
1)Cilindro (White Martins Gases Industriais S.A., Bauru, SP, Brasil)

Este artefato serve para acondicionar o nitrogênio utilizado para pressurização do sistema (Figura 7a). É constituído por uma válvula que libera o nitrogênio do cilindro e um regulador de pressão com dois manômetros, um para medir a pressão interna do cilindro e outro para medir a pressão de trabalho.

O sistema começa a funcionar quando a válvula é aberta e libera o nitrogênio. A partir daí, o regulador de pressão é manipulado para determinar a pressão de trabalho que equivale a $703,1 \mathrm{cmH}_{2} \mathrm{O}$. Esta pressão é mantida constante em todos os testes.

\section{2)Câmara de pressão}

A câmara de pressão é ligada ao cilindro por meio de um tubo de polietileno para receber o nitrogênio pressurizado. É a modificação de uma panela de pressão doméstica (Figura $7 b$ ) a qual possui, no seu interior, um reservatório com capacidade de armazenar $600 \mathrm{ml}$ de água deionizada (Figura 7c). Do interior do reservatório projeta-se um capilar de polietileno que, através de um dispositivo de acoplagem localizado na tampa da câmara de pressão, comunica-se com o sistema capilar externo, destinado a conduzir a água deionizada sob a pressão de nitrogênio. $O$ volume de água deionizada era reposto periodicamente durante o procedimento de filtração. A câmara de pressão, sendo hermeticamente fechada, possibilitava a indução de uma pressão constante através de todo o sistema capilar abastecido com água deionizada. 


\section{3)Sistema capilar de polietileno}

O sistema de capilares (CPL Medical's Produtos Médicos Ltda. São Paulo, SP, Brasil) funciona como elo de união entre a câmara de pressão e a câmara de filtração e neste percurso encontram-se dois importantes componentes: a micropipeta e a microseringa. A micropipeta, com $65 \mathrm{~mm}$ de comprimento e capacidade de $25 \mu$ l está justaposta a uma escala de medição em milímetros, que servirá para medir o deslocamento do líquido numa fração de tempo, conforme a velocidade de filtração dos discos de dentina (Figura 7d). 0 deslocamento da água deionizada é visualizado através da movimentação de uma microbolha criada pela microseringa acoplada a uma extensão capilar entre a micropipeta e a câmara de filtração. A microseringa é composta por um reservatório com água deionizada e um cursor (Figura 7e). Tem as funções de formar a bolha de ar e de posicioná-la adequadamente na micropipeta, ajustando-a na escala milimetrada.

\section{4)Câmara de filtração}

A câmara de filtração (Biomedical Engineering Augusta, Georgia, EUA.) é a parte final do sistema que abriga os espécimes de dentina e fica conectada à câmara de pressão por meio dos capilares de polietileno. A câmara de filtração é composta por duas bases de plexiglas que se encaixam por rosqueamento (Figuras $7 f$ e 8 ). A base inferior apresenta dois orifícios para circulação do líquido sob pressão. Um é ligado ao sistema pelos capilares de polietileno e funciona como local de entrada do líquido pressurizado na câmara. $\mathrm{O}$ 
outro, no extremo oposto, é destinado a drenagem de líquido para remoção de bolhas de ar. A base superior apresenta uma abertura central através da qual se tem acesso ao disco de dentina (Figura 9). Tanto a base inferior quanto a superior da câmara recebem discos, também de plexiglas, com abertura central, de diâmetros padronizados de 0,178 ou $0,282 \mathrm{~cm}^{2}$ conforme o tamanho dos espécimes de dentina. Em ambos os discos de plexiglas são adaptados anéis de borracha para vedação que impedem o extravasamento de pressão e, consequentemente, da água deionizada durante os procedimentos de filtração. Entre os discos de plexiglas, superior e inferior, adapta-se 0 disco de dentina que, após o rosqueamento do segmento superior da câmara de filtração e sob pressão dos anéis de borracha, determina dois espaços independentes, um voltado para o exterior, correspondente à superfície dentinária oclusal e, outro, voltado para o interior, correspondendo à câmara pulpar. Desta forma a passagem de líquido de um compartimento para outro é função da permeabilidade do disco de dentina. Para garantir a padronização da área dentinária exposta aos testes, os anéis de vedação superior e inferior em contato com o espécime têm diâmetros correspondentes às aberturas dos discos de plexiglas, definindo áreas respectivas de 0,178 ou $0,282 \mathrm{~cm}^{2}$.

O disco de dentina é, então, posicionado entre os discos de plexiglas, com o lado pulpar voltado para a base inferior, em contato direto com o líquido sob pressão, simulando as condições in vivo, enquanto o lado oclusal fica voltado para a base superior. Como a base superior apresenta um orifício central, o lado oclusal fica exposto ao meio externo e, portanto, disponível para a aplicação dos materiais em teste. A área de dentina exposta, delimitada pelos anéis de 
borracha em contato com o disco, era definida conforme o tamanho e características anatômicas do espécime.

\subsection{Padronização dos espécimes:}

Cada espécime foi tratado com EDTA a 0,5M em pH 7,4 por dois minutos em ambas as faces do disco, lavados abundantemente com água deionizada e submetidos à medição da filtração. Os discos foram agrupados de acordo com índices de filtração, o que possibilitou o uso de cinquenta espécimes com índice de filtração variando de 10 a $30 \mu \mathrm{l} / \mathrm{min}$. (gráfico I). Discos com filtrações diferentes destas foram descartados, tornando a amostra a mais homogênea possível.

GRÁFICO 1 - Distribuição dos espécimes de acordo com índices iniciais de filtração.

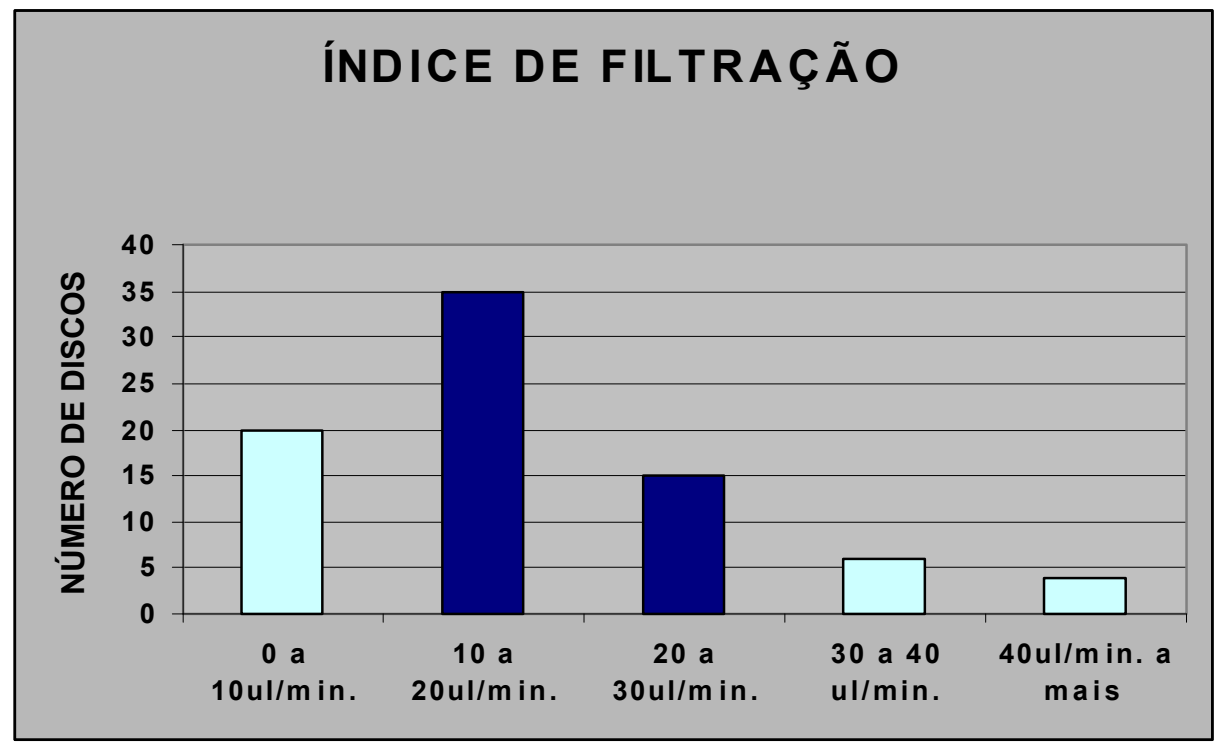




\subsection{Materiais empregados}

No presente estudo foi avaliado o potencial de obstrução dos túbulos dentinários pelos agentes anti-hiperestésicos comercial e experimentais.

A tabela 1 mostra a composição dos materiais utilizados e o fabricante.

TABELA 1 - Composição dos materiais e fabricante

\begin{tabular}{|c|c|c|}
\hline MATERIAL & COMPOSIÇÃO & FABRICANTE \\
\hline OXA-GEL & 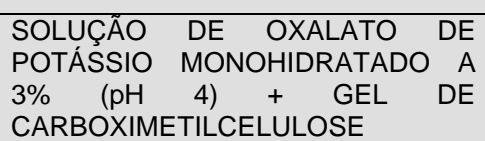 & $\begin{array}{l}\text { ART-DENT - Ind. e Com. de } \\
\text { Produtos Odontológicos } \\
\text { Ltda./ BRASIL }\end{array}$ \\
\hline DD-1 & 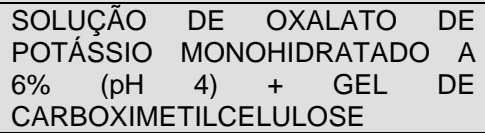 & EXPERIMENTAL \\
\hline DD-2 & $\begin{array}{l}\text { SOLUÇÃO DE OXALATO DE } \\
\text { POTÁSIO MONOHIDRATADO A } \\
\text { 3\% (pH 2,5) + GEL DE CARBOPOL }\end{array}$ & EXPERIMENTAL \\
\hline PLACEBO & $\begin{array}{l}\text { CARBOXIMETILCELULOSE + } \\
\text { ÁGUA DEIONIZADA }\end{array}$ & CONTROLE \\
\hline ÁGUA DEIONIZADA & & CONTROLE \\
\hline
\end{tabular}

\subsection{Realização dos testes}

\subsubsection{Definição dos grupos experimentais}

A condutividade hidráulica da dentina pode ser entendida como a passagem de líquidos através dos túbulos dentinários sob uma determinada pressão. Constitui em um dos métodos estabelecidos para se quantificar a permeabilidade dentinária. 
Os 50 discos selecionados foram divididos em 5 grupos de 10 dentes cada. No grupo I utilizou-se o OXA-GEL, no grupo II, o agente DD-1, no grupo III, o agente DD-2, no grupo IV, um agente placebo, como controle para o material e no grupo $\mathrm{V}$, água deionizada, como controle para o sistema de filtração (Figura 10).

Os materiais utilizados, número de grupos e espécimes avaliados podem ser vistos na Tabela 2:

TABELA 2 - Materiais empregados, números de grupos e espécimes.

\begin{tabular}{c|c|c|}
\hline GRUPO & MATERIAL & $\mathbf{N}^{\circ}$ de ESPÉCIMES \\
\hline I & OXA-GEL & 10 \\
\hline II & DD-1 & 10 \\
\hline III & DD-2 & 10 \\
\hline IV & PLACEBO & 10 \\
\hline V & ÁGUA DEIONIZADA & 10 \\
\hline
\end{tabular}

Os discos de dentina foram submetidos ao processo de filtração, quando a passagem do líquido no interior dos túbulos dentinários foi medida pela movimentação de uma pequena bolha de ar localizada na micropipeta justaposta a uma escala milimétrica, em um determinado espaço de tempo e expressa em condutividade hidráulica. Como a micropipeta apresenta o diâmetro interno constante, a divisão de sua capacidade volumétrica pelo seu comprimento resulta numa proporcionalidade constante que converte o deslocamento linear em seu interior, no deslocamento de líquidos através do disco de dentina. Todas as medições foram executadas com a mesma pressão, e a área de dentina em que se 
mediu a filtração foi delimitada por anéis circulares de borracha conforme descrito anteriormente.

\subsubsection{Determinação da condutividade hidráulica da dentina}

Duas situações básicas foram adotadas para a determinação do efeito dos materiais e variáveis estudadas sobre a condutividade hidráulica da dentina. A primeira considera que a presença da smear layer é a condição mais efetiva para obstruir os túbulos dentinários e reduzir o fluxo de líquido através da dentina. A segunda aceita que a desmineralização é a condição que permite maior permeabilidade da dentina. Assim, a condutividade hidráulica dos espécimes era medida, inicialmente, na presença de smear layer, em seguida após sua remoção através de condicionamento, estabelecendo-se, desta maneira os valores de permeabilidade mínima e máxima de cada espécime, individualmente.

Para a obtenção da permeabilidade mínima procedia-se a simulação da smear-layer no lado oclusal, a qual era obtida, através do lixamento dos espécimes por dez segundos em lixa umedecida de carbureto de silício de granulação 600 sob pressão manual. Os espécimes eram, então, colocados no interior da câmara com o lado pulpar posicionado internamente à câmara de filtração, em contato direto com o líquido sob pressão, e o lado oclusal voltado para o meio externo. Após este procedimento, media-se a filtração, obtendo-se a permeabilidade mínima.

Obtinha-se a permeabilidade máxima submetendo os espécimes à desmineralização com EDTA a 0,5M, pH 7,4 por dois minutos para 
completa remoção da smear layer. Os índices assim obtidos eram considerados 100\% da filtração de cada espécime. Os demais índices, incluindo os efeitos dos materiais experimentais e da smear layer, eram calculados como uma proporção da permeabilidade máxima (100\%).

Em seguida à medição da permeabilidade máxima aplicavam-se os agentes anti-hiperestésicos na superfície exposta do disco de dentina, conforme exposto na tabela II por 3 minutos, lavava-se abundantemente com água deionizada e media-se a filtração imediatamente por quatro vezes consecutivas. As medições eram repetidas por mais quatro vezes para cada intervalo de tempo estabelecido para este estudo, a saber 5, 15 e 30 minutos após a medição inicial, esta denominada condutividade hidráulica imediata.

Das quatro medições realizadas para cada condição obtinha-se a média aritmética com a qual se calculava a porcentagem em relação à permeabilidade máxima. Este percentual traduzia a permeabilidade dos discos sob efeito dos agentes aplicados, tendo o tempo como uma das variáveis.

Após as medições do intervalo de 30 minutos, a superfície tratada dos espécimes era submetida ao condicionamento com ácido cítrico a $6 \%$ pH 2 por 1 minuto. Tal tratamento, tinha a finalidade de avaliar a resistência dos eventuais efeitos oclusivos dos materiais estudados a um meio ácido recorrente e é aqui referido como desafio ácido. Durante todas as medições, os espécimes permaneciam montados na câmara de filtração e a pressão era mantida constante.

Esta sequência de procedimentos repetia-se para todos os grupos experimentais. No grupo V, onde não foi utilizado material algum, registravam-se as permeabilidades mínima e máxima e permitia-se a simples 
filtração de água deionizada pelos intervalos de tempo estudados, anotando-se os seus valores para efeito de comparação com os demais grupos. Tal procedimento objetivava considerar um eventual arrefecimento espontâneo do processo de filtração com o passar do tempo.

Os resultados das medições eram organizados em uma ficha a qual contém para todas as condições, a distância percorrida pela bolha e o tempo necessário para percorrê-la, a condutividade hidráulica, média aritmética das condutividades hidráulicas e seus valores relativos em porcentagem.(Quadro I)

\subsection{Cálculo da filtração e da condutividade hidráulica:}

Com todas as medições concluídas, tendo em mãos a distância percorrida pela bolha e o tempo gasto para tal, foram feitos os cálculos da condutividade hidráulica.

A condutividade hidráulica (Lp) é o resultado do quociente entre a filtração dentinária $(\mathrm{Q})$ e a pressão utilizada $(P)$ multiplicada pela área de superfície (AS), expressa em $\mu \mathrm{l} \cdot \mathrm{cm}^{-2} \cdot \mathrm{min}^{-1} \cdot \mathrm{cmH}_{2} \mathrm{O}^{-1}$ :

$$
L p=\frac{Q}{P \times A S}
$$

onde $Q$ é a filtração dentinária, resultado do produto entre a capacidade do microcapilar $(25 \mu \mathrm{l})$ e distância percorrida pela bolha $(\mathrm{x} \mathrm{mm})$, dividido pelo produto entre o comprimento do microcapilar $(65 \mathrm{~mm})$ e o tempo (y min) do percurso da bolha numa distância $x$. A filtração dentinária é expressa em $\mu \mathrm{l} \cdot \min ^{-1}$

$$
Q=\frac{25 \mu l .(x) \mathrm{mm}}{65 \mathrm{~mm} .(y) \min }
$$


P é a pressão, sempre constante e estabelecida a $703,1 \mathrm{cmH}_{2} \mathrm{O}$, e $\mathrm{AS}$, a área de superfície determinada pelo diâmetro da câmara utilizada, podendo ser de $0,178 \mathrm{~cm}^{2}$ ou $0,282 \mathrm{~cm}^{2}$.

Nota-se portanto, que alguns parâmetros são constantes, mudando apenas a área, o tempo e a distância percorrida pela bolha, que são inerentes a cada espécime. Como forma de simplificar o cálculo da condutividade hidráulica foram feitas duas constantes com os números fixos, de acordo com a área de superfície empregada.

A condutividade hidráulica para área de superfície $0,282 \mathrm{~cm}^{2}$

é:

$$
L p=0,0019398155 .(x) \mathrm{mm}
$$

(y)min

A condutividade hidráulica para área de superfície $0,178 \mathrm{~cm}^{2}$

é:

$$
L p=\frac{0,0030731909 .(x) \mathrm{mm}}{(y) \mathrm{min}}
$$

\subsection{Análise estatística dos dados:}

Os resultados foram submetidos à análise de variância a dois critérios (material $\mathrm{x}$ tempo) para a verificação da existência de diferenças significantes. Onde houve diferenças estatísticas significantes aplicou-se o teste de Duncan para identificá-las. Para todos os testes convencionou-se um nível de significância de $5 \%(p<0,05)$. 
O quadro I mostra o esquema idealizado para cada espécime:

\section{QUADRO I - Esquema representativo da medição da condutividade}

\section{hidráulica.}

Data Analisado por Disco $n^{\circ}$

Microcapilar $\mu \mathrm{l} \_\mathrm{mm}$ Área $\mathrm{cm}^{2}$ Pressão $\mathrm{cmH}_{2} \mathrm{O}$

Experimento: Material utilizado

\begin{tabular}{|c|c|c|c|}
\hline \multicolumn{3}{|c|}{ 1.CONDIÇÃO } & MÍNIMA \\
\hline & $\mathrm{mm}$ & $\mathbf{m i n}$ & Lp \\
\hline 1 & $\mathrm{x}$ & $\mathrm{y}$ & \\
\hline 2 & $\mathrm{x}$ & $\mathrm{y}$ & \\
\hline 3 & $\mathrm{x}$ & $\mathrm{y}$ & \\
\hline 4 & $\mathrm{x}$ & $\mathrm{y}$ & \\
\hline $\mathrm{X}$ & \multicolumn{3}{|l|}{} \\
\hline$\%$ & \multicolumn{3}{|l}{} \\
\hline
\end{tabular}

\begin{tabular}{|l|l|l|l|}
\hline 1 & $\mathrm{x}$ & $\mathrm{y}$ & \\
\hline 2 & $\mathrm{x}$ & $\mathrm{y}$ & \\
\hline 3 & $\mathrm{x}$ & $\mathrm{y}$ & \\
\hline 4 & $\mathrm{x}$ & $\mathrm{y}$ & \\
\hline $\mathrm{X}$ & \multicolumn{4}{|c|}{} \\
\hline$\%$ & \multicolumn{4}{|c|}{100} \\
\hline
\end{tabular}

\begin{tabular}{|c|c|c|c|}
\hline \multicolumn{3}{|c|}{ 3.CONDIÇÃO } & MATERIAL IMEDIATO \\
\hline & $\mathbf{m m}$ & min & Lp \\
\hline 1 & $\mathrm{x}$ & $\mathrm{y}$ & \\
\hline $\mathbf{2}$ & $\mathrm{x}$ & $\mathrm{y}$ & \\
\hline 3 & $\mathrm{x}$ & $\mathrm{y}$ & \\
\hline $\mathbf{4}$ & $\mathrm{x}$ & $\mathrm{y}$ & \\
\hline $\mathrm{X}$ & \multicolumn{4}{|l|}{} \\
\hline$\%$ & \multicolumn{4}{|}{} \\
\hline
\end{tabular}

\begin{tabular}{|c|c|c|c|}
\hline 4.CONDIÇÃO & MATERIAL (5') \\
\hline & mm & $\min$ & Lp \\
\hline 1 & $\mathrm{x}$ & $\mathrm{y}$ & \\
\hline 2 & $\mathrm{x}$ & $\mathrm{y}$ & \\
\hline 3 & $\mathrm{x}$ & $\mathrm{y}$ & \\
\hline 4 & $\mathrm{x}$ & $\mathrm{y}$ & \\
\hline $\mathrm{X}$ & \multicolumn{4}{|c|}{} \\
\hline$\%$ & \multicolumn{3}{|l}{} \\
\hline
\end{tabular}

\begin{tabular}{|c|c|c|c|}
\hline \multicolumn{3}{|c|}{ 5.CONDIÇÃO } & \multirow{2}{*}{$\begin{array}{c}\text { MATERIAL (15') } \\
\text { Lp }\end{array}$} \\
\hline & $\mathrm{mm}$ & $\min$ & \\
\hline 1 & $x$ & y & \\
\hline 2 & $x$ & $y$ & \\
\hline 3 & $x$ & $y$ & \\
\hline 4 & $x$ & $y$ & \\
\hline $\mathbf{X}$ & & & \\
\hline$\%$ & & & \\
\hline
\end{tabular}

\begin{tabular}{|c|c|c|c|}
\hline \multicolumn{6}{|c|}{ 6.CONDIÇÃO } & MATERIAL (30') \\
\hline & $\mathbf{m m}$ & $\min$ & Lp \\
\hline $\mathbf{1}$ & $\mathrm{x}$ & $\mathrm{y}$ & \\
\hline $\mathbf{2}$ & $\mathrm{x}$ & $\mathrm{y}$ & \\
\hline 3 & $\mathrm{x}$ & $\mathrm{y}$ & \\
\hline 4 & $\mathrm{x}$ & $\mathrm{y}$ & \\
\hline $\mathbf{X}$ & \multicolumn{4}{|c|}{} \\
\hline$\%$ & \multicolumn{4}{|c|}{} \\
\hline
\end{tabular}

\begin{tabular}{|c|c|c|c|}
\hline \multicolumn{3}{|c|}{ 7.CONDIÇÃO } & DESAFIO ÁCIDO \\
\hline & $\mathrm{mm}$ & $\min$ & Lp \\
\hline 1 & $x$ & $y$ & \\
\hline 2 & $x$ & $y$ & \\
\hline 3 & $x$ & $y$ & \\
\hline 4 & $x$ & $y$ & \\
\hline $\bar{X}$ & & & \\
\hline
\end{tabular}

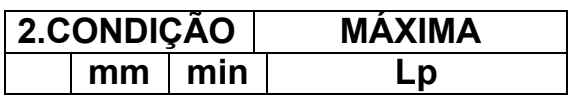




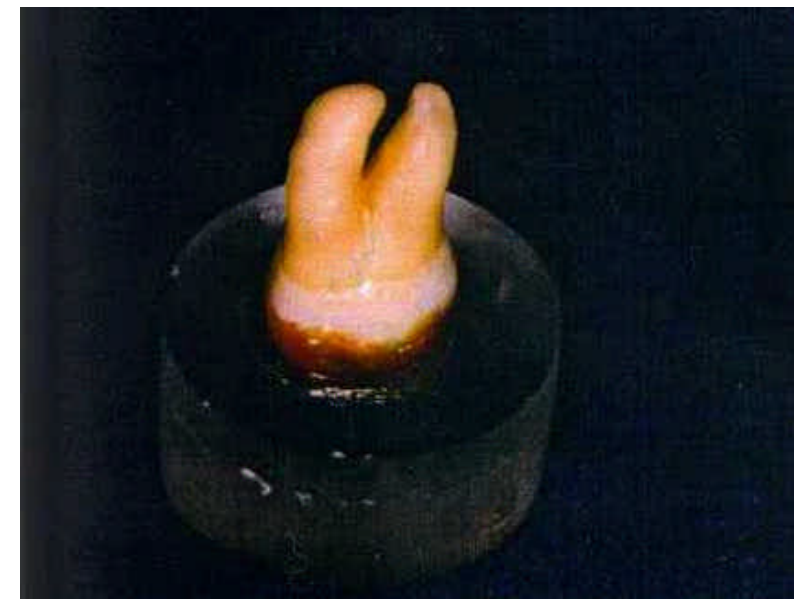

Figura 1 - Dente fixado a um dispositivo de resina epóxica

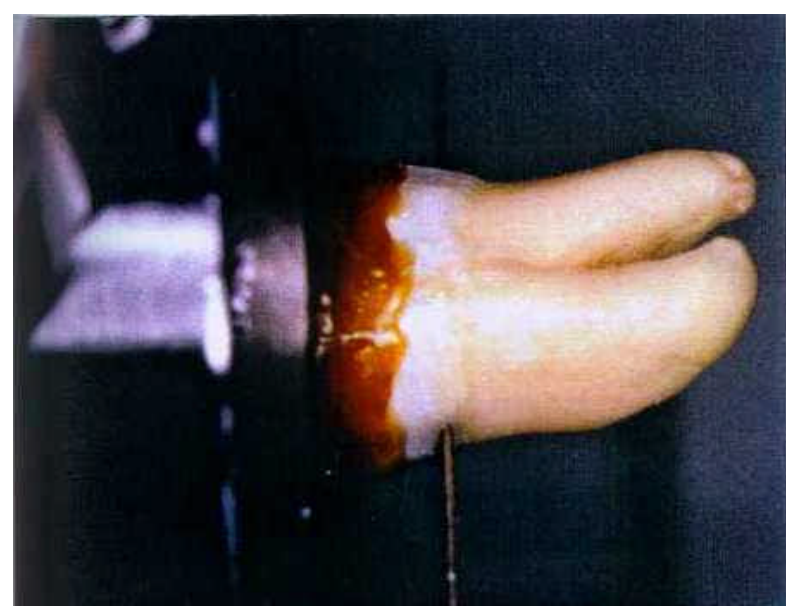

Figura 3 - Visão aproximada da realização do primeiro corte com remoção da raiz

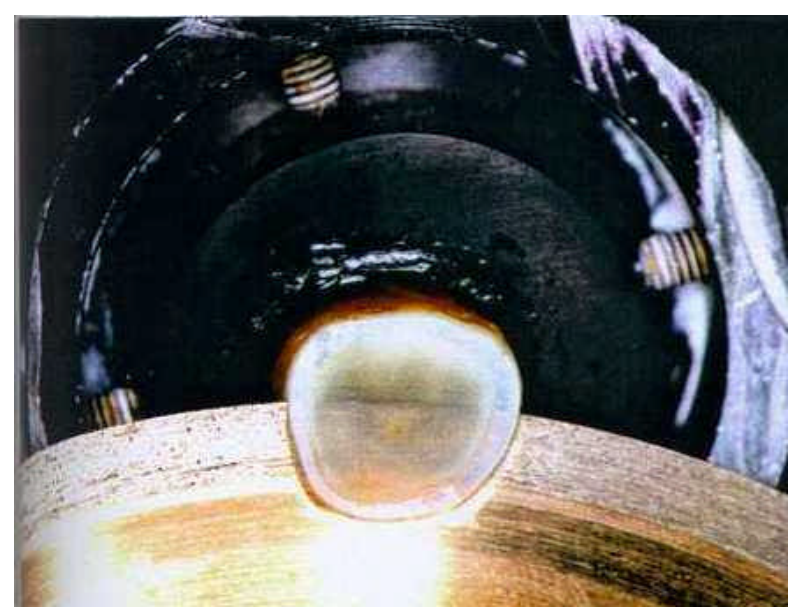

Figura 5 - Outra visão da realização do segundo corte, mostrando a superfície central em dentina

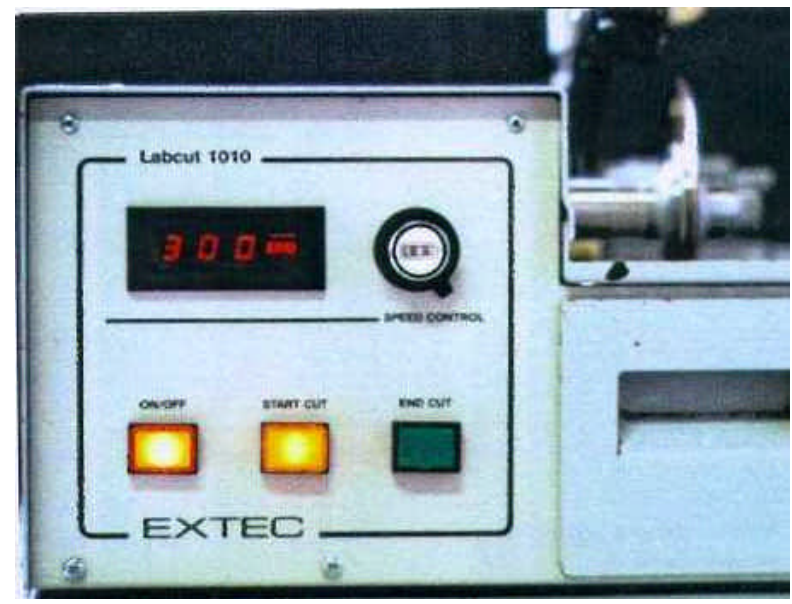

Figura 2 - Aspecto da máquina de corte com o disco diamantado em posição

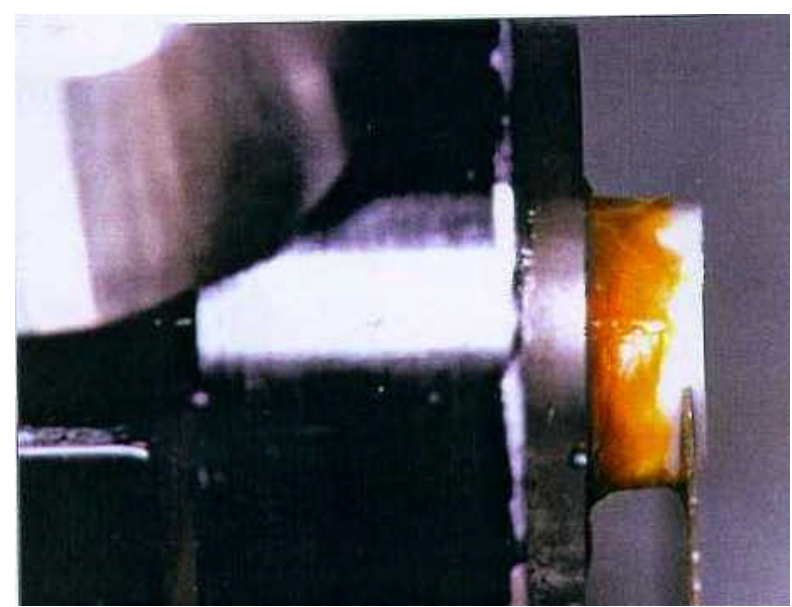

Figura 4 - Realização do segundo corte e obtenção do espécime

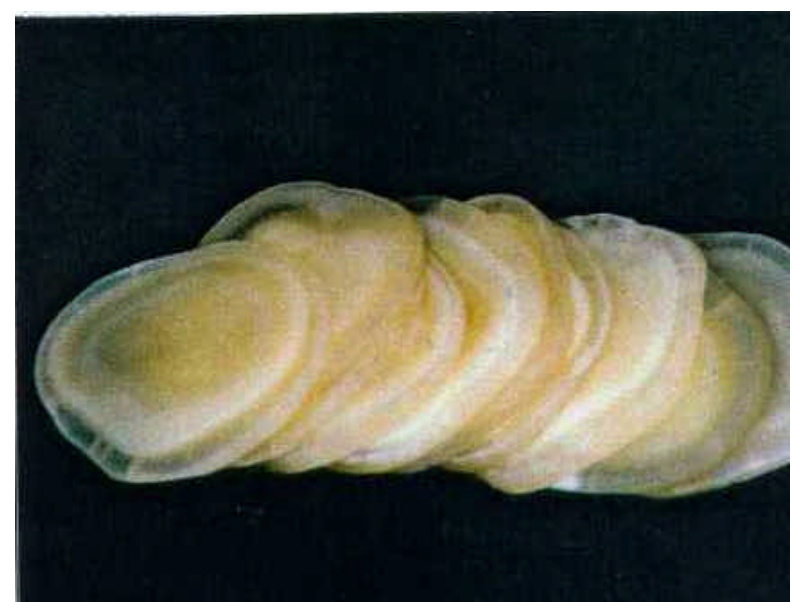

Figura 6 - Visão geral dos espécimes obtidos após a realização dos cortes 


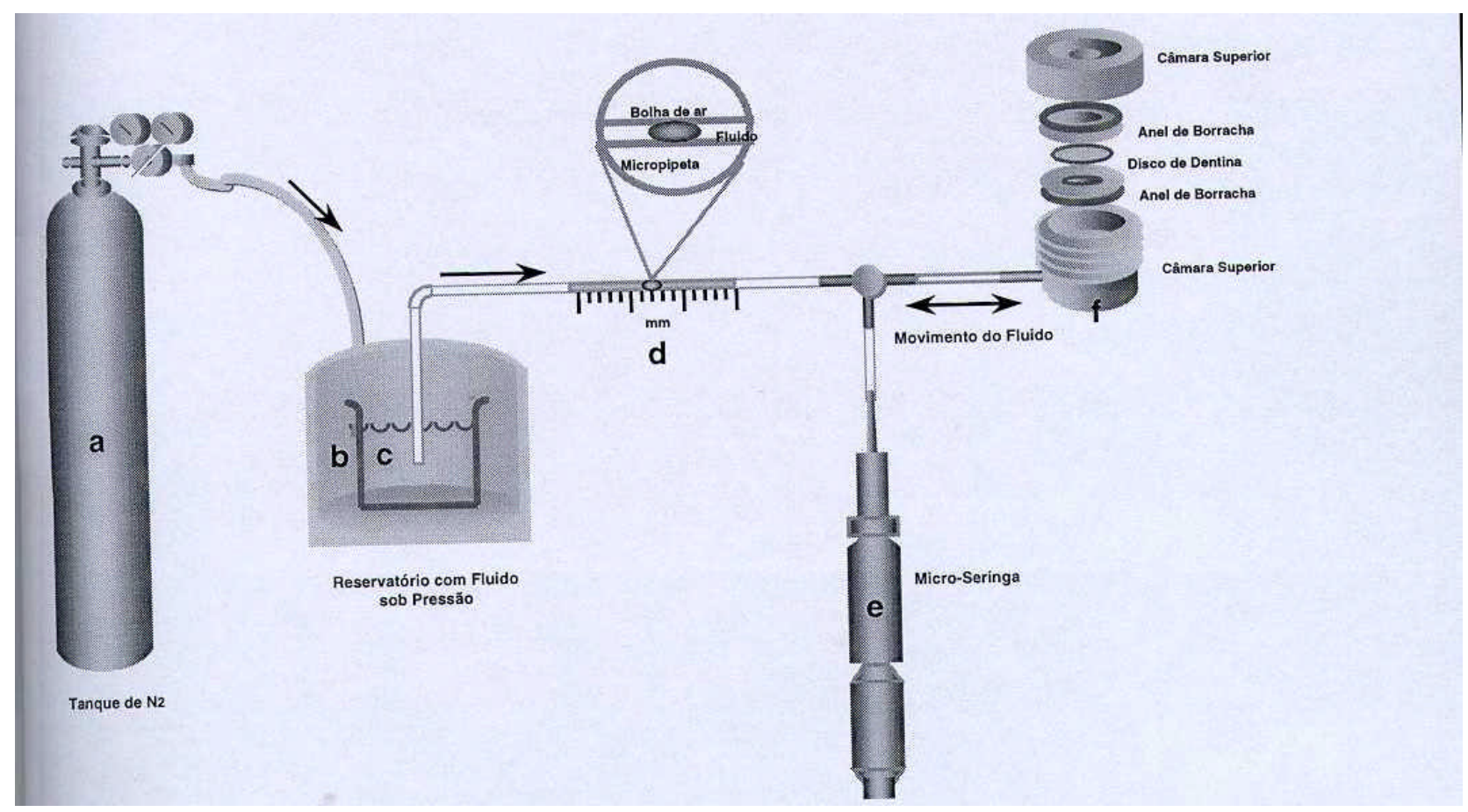

Figura 7 - Dispositivo utilizado para medição da condutibilidade hidráulica da dentina (Adaptado de PASHLEY e GALLOWAY, 1985) 


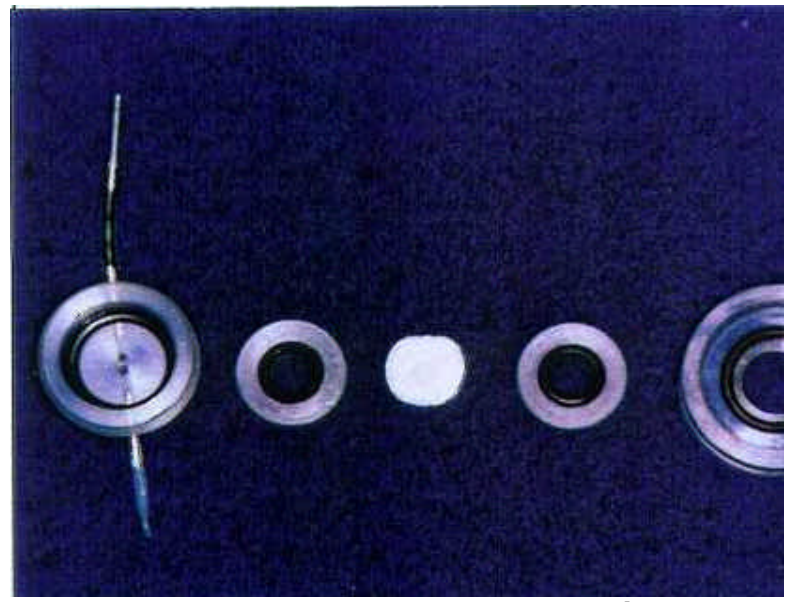

Figura 8 - Partes constituintes da câmara de filtração com o disco de dentina na posição central

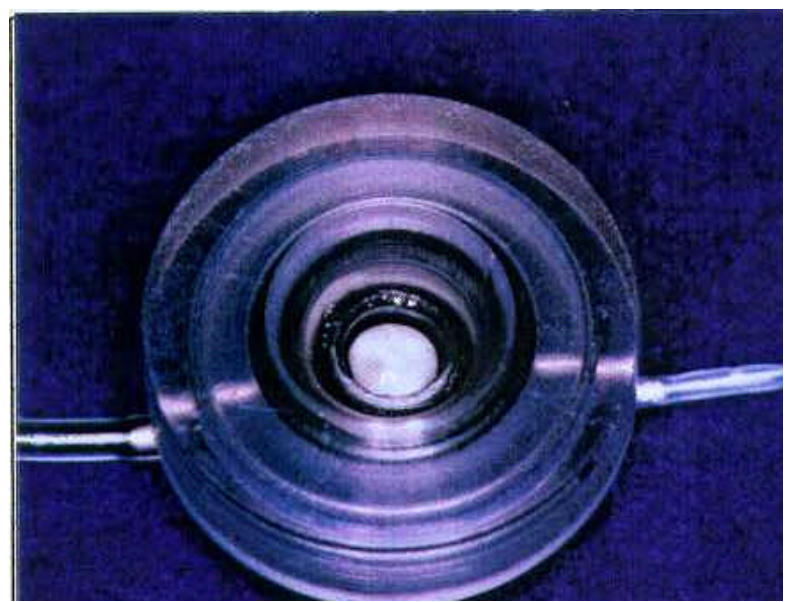

Figura 9 - Câmara de filtração fechada e aspecto da área de dentina exposta

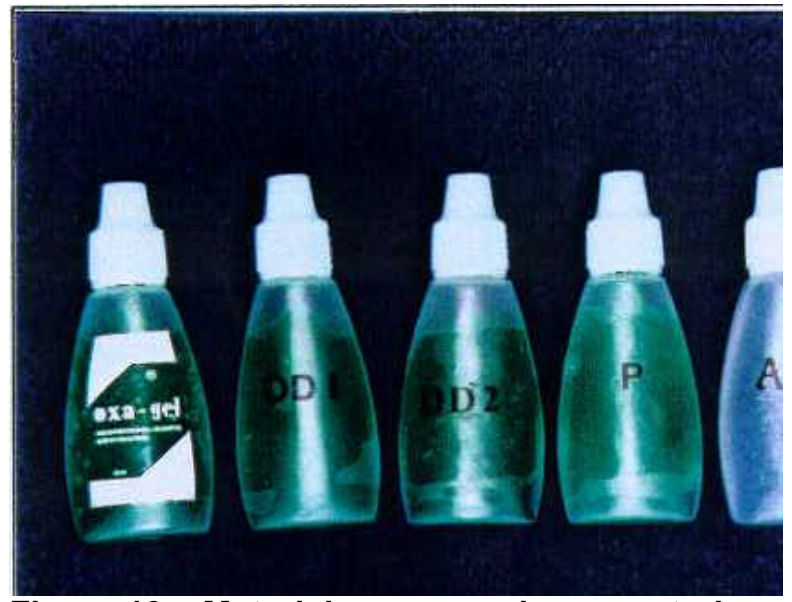

Figura 10 - Materiais empregados no estudo 


\section{Resultados}

Os valores (média e desvio padrão) da condutividade hidráulica, expressos em porcentagem, encontram-se descritos na tabela 3 . Podemos detectar uma tendência da redução proporcional da condutividade hidráulica considerando o fator tempo. Os materiais ativos (OXA-GEL, DD-1 e DD-2) apresentaram valores similares, diferindo, entretanto, do agente PLACEBO e ÁGUA DEIONIZADA. Nos anexos 1, 2, 3, 4 e 5 apresentamos os valores individuais de todos os espécimes para cada grupo.

TABELA 3 - Médias e desvio padrão, expressos em porcentagem, da condutividade hidráulica para cada material nas condições testadas.

\begin{tabular}{cccccc}
\hline & OXA-GEL & DD-1 & DD-2 & PLACEBO & ÁGUA DEIONIZADA \\
\hline MÍNIMA & $26,14 \pm 23,58$ & $16,22 \pm 27,22$ & $28,91 \pm 29,62$ & $31,22 \pm 20,61$ & $32,31 \pm 23,97$ \\
MÁXIMA & 100 & 100 & 100 & 100 & 100 \\
IMEDIATO & $23,03 \pm 11,96$ & $21,76 \pm 9,95$ & $29,71 \pm 12,75$ & $72,76 \pm 15,06$ & $74 \pm 15,35$ \\
5 MIN. & $17,14 \pm 9,69$ & $16.09 \pm 8,02$ & $22,69 \pm 10,22$ & $54,99 \pm 13,5$ & $61,96 \pm 16,06$ \\
15 MIN. & $13,46 \pm 7,72$ & $12,09 \pm 6,13$ & $17,01 \pm 8,8$ & $44,19 \pm 11,91$ & $48,03 \pm 14,56$ \\
30 MIN. & $11,03 \pm 6,39$ & $9,09 \pm 4,59$ & $13,78 \pm 7,01$ & $35,5 \pm 8,6$ & $37,69 \pm 13,35$ \\
DESAFIO & $17,63 \pm 8,56$ & $16,71 \pm 6,53$ & $22,61 \pm 12,54$ & $65,78 \pm 28,69$ & $86,57 \pm 52,19$ \\
\hline
\end{tabular}

Com a finalidade de determinar se essas diferenças observadas eram estatisticamente significantes os valores foram submetidos à análise de variância a dois critérios com nível de significância de 5\%, observando-se 
diferenças significantes entre material, condição e interação material x condição (Tabela 4).

TABELA 4 - Análise de variância a dois critérios (material x condição)

\begin{tabular}{lcccccc}
\hline & $\begin{array}{c}\text { GRAUS DE } \\
\text { LIBERDADE } \\
\text { (EFEITO) }\end{array}$ & $\begin{array}{c}\text { QUADRADO } \\
\text { MÉDIO } \\
\text { (EFEITO) }\end{array}$ & $\begin{array}{c}\text { GRAUS DE } \\
\text { LIBERDADE } \\
\text { (ERRO) }\end{array}$ & $\begin{array}{c}\text { QUADRADO } \\
\text { MÉDIO } \\
\text { (ERRO) }\end{array}$ & F & P \\
\hline MATERIAL & 4 & 19610,29 & 45 & 732,1710 & 26,7838 & $0,0000^{*}$ \\
CONDIÇÃO & 6 & 35831,91 & 270 & 193,1674 & 185,4966 & $0,0000^{*}$ \\
INTERAÇÃO & 24 & 1386,57 & 270 & 193,1674 & 7,1781 & $0,0000^{*}$ \\
\hline
\end{tabular}

Tendo ocorrido interação estatisticamente significante, foram feitas, em seguida, as comparações individuais para detectar as diferenças entre os materiais e entre as condições testadas para cada material. Para essas comparações individuais foi utilizado o teste de Duncan com nível de significância de $5 \%$ (Tabelas 5 e 6$)$.

Analisando a tabela 5 conclui-se que não houve diferenças estatísticas significantes em relação à mínima permeabilidade para todos os materiais. E, não houve diferenças estatísticas entre o OXA-GEL, DD-1 e DD-2 em todas as condições testadas (imediato, 5, 15, 30 minutos e desafio), bem como entre o agente PLACEBO e a ÁGUA DEIONIZADA. No entanto, foram detectadas diferenças estatisticamente significantes entre os agentes anti-hiperstésicos OXAGEL, DD-1 e DD-2 e o agente PLACEBO e a ÁGUA DEIONIZADA. 
TABELA 5 - Teste de Duncan da comparação entre os materiais nas condições testadas

\begin{tabular}{|c|c|c|c|c|c|c|}
\hline & MÍNIMA & IMEDIATO & 5 MIN. & 15 MIN. & 30 MIN. & DESAFIO \\
\hline $\begin{array}{l}\text { OXA-GEL } \quad x \\
\text { DD-1 }\end{array}$ & 0,383 & 0,830 & 0,844 & 0,768 & 0,613 & 0,940 \\
\hline $\begin{array}{l}\text { OXA-GEL } \quad x \\
\text { DD-2 }\end{array}$ & 0,806 & 0,262 & 0,301 & 0,443 & 0,475 & 0,688 \\
\hline $\begin{array}{l}\text { OXA-GEL } \quad X \\
\text { PLACEBO }\end{array}$ & 0,674 & $0,000^{*}$ & $0,000^{*}$ & $0,000^{*}$ & $0,000^{*}$ & $0,000^{*}$ \\
\hline $\begin{array}{l}\text { OXA-GEL X } \\
\text { ÁGUA DEIO. }\end{array}$ & 0,623 & $0,000^{*}$ & $0,000^{*}$ & $0,000^{*}$ & $0,000^{*}$ & $0,000^{*}$ \\
\hline DD-1 x DD-2 & 0,295 & 0,209 & 0,247 & 0,320 & 0,253 & 0,656 \\
\hline $\begin{array}{l}\text { DD-1 } \\
\text { PLACEBO }\end{array}$ & 0,232 & $0,000^{*}$ & $0,000^{*}$ & $0,000^{*}$ & $0,000^{*}$ & $0,000^{*}$ \\
\hline $\begin{array}{l}\text { DD-1 x ÁGUA } \\
\text { DEIONIZADA }\end{array}$ & 0,211 & $0,000^{*}$ & $0,000^{*}$ & $0,000^{*}$ & $0,000^{*}$ & $0,000^{*}$ \\
\hline $\begin{array}{l}\text { DD-2 } \\
\text { PLACEBO }\end{array}$ & 0,838 & $0,000^{*}$ & $0,000^{*}$ & $0,000^{*}$ & $0,000^{*}$ & $0,001^{*}$ \\
\hline $\begin{array}{l}\text { DD-2 x ÁGUA } \\
\text { DEIONIZADA }\end{array}$ & 0,778 & $0,000^{*}$ & $0,000^{*}$ & $0,000^{*}$ & $0,000^{*}$ & $0,000^{*}$ \\
\hline $\begin{array}{l}\text { PLACEBO } x \\
\text { ÁGUA DEIO. }\end{array}$ & 0,923 & 0,833 & 0,195 & 0,407 & 0,569 & 0,099 \\
\hline
\end{tabular}

*diferença estatisticamente significante $(p<0,05)$.

A tabela 6 mostra as diferenças ocorridas entre as variáveis de tempo testadas para todos os materiais através da aplicação do teste de Duncan. Para os grupos I e III (OXA-GEL e DD-2) houve uma redução dos valores de permeabilidade em função do tempo, e esta redução só foi estatisticamente significante aos 15 e 30 minutos após a aplicação. Para o grupo II (DD-1) houve redução significante dos valores de permeabilidade em função do tempo somente aos 30 minutos, embora, nesse mesmo grupo, a significância estatística tenha ficado próxima quando se analisa a comparação entre imediato e 15 minutos. No grupo IV 
(PLACEBO) encontrou-se significância aos 5, 15 e 30 minutos. No grupo V (ÁGUA DEIONIZADA) verificando a influência do dispositivo de medição na redução da permeabilidade, observou-se redução da permeabilidade embora nenhum agente tenha sido empregado.

TABELA 6 - Teste de Duncan da comparação de cada intervalo de tempo nos diferentes materiais testados

\begin{tabular}{|c|c|c|c|c|c|}
\hline & OXA-GEL & DD-1 & DD-2 & PLACEBO & $\begin{array}{c}\text { ÁGUA } \\
\text { DEIONIZADA }\end{array}$ \\
\hline $\begin{array}{l}\text { IMEDIATO x } 5 \\
\text { MIN. }\end{array}$ & 0,150 & 0,249 & 0,185 & $0,009^{*}$ & 0,221 \\
\hline $\begin{array}{l}\text { IMEDIATO x } \\
15 \text { MIN. }\end{array}$ & $0,023^{*}$ & 0,053 & $0,023^{*}$ & $0,000^{*}$ & $0,013^{*}$ \\
\hline $\begin{array}{l}\text { IMEDIATO x } \\
30 \text { MIN. }\end{array}$ & $0,005^{*}$ & $0,012^{*}$ & $0,004^{*}$ & $0,000^{*}$ & $0,000^{*}$ \\
\hline $\begin{array}{l}5 \text { MIN. x } 15 \\
\text { MIN. }\end{array}$ & 0,338 & 0,368 & 0,283 & 0,093 & 0,158 \\
\hline $\begin{array}{c}5 \text { MIN. } \times 30 \\
\text { MIN }\end{array}$ & 0,135 & 0,139 & 0,104 & $0,004^{*}$ & $0,020^{*}$ \\
\hline $\begin{array}{l}15 \text { MIN. x } 30 \\
\text { MIN. }\end{array}$ & 0,527 & 0,499 & 0,514 & 0,175 & $0,292^{*}$ \\
\hline
\end{tabular}

Após a aplicação dos materiais foi realizado um desafio ácido para comprovar a efetividade dos agentes utilizados. Para o OXA-GEL, DD-1 e DD-2 este desafio ficou a níveis próximos da mínima permeabilidade, sendo estatisticamente diferente apenas para o oxa-gel (a menor). Já para a água deionizada e o placebo estes valores ficaram próximos à máxima permeabilidade, sendo estatisticamente diferente para o placebo (Tabela 7). 
TABELA 7 - Teste de Duncan comparando o desafio ácido com as permeabilidades mínima e máxima

\begin{tabular}{cccccc}
\hline & OXA-GEL & DD-1 & DD-2 & PLACEBO & $\begin{array}{c}\text { ÁGUA } \\
\text { DEIONIZADA }\end{array}$ \\
\hline $\begin{array}{c}\text { DESAFIO x } \\
\text { MÍNIMA }\end{array}$ & $0,038^{*}$ & 0,912 & 0,234 & $0,000^{*}$ & $0,000^{*}$ \\
$\begin{array}{c}\text { DESAFIO x } \\
\text { MÁXIMA }\end{array}$ & $0,000^{*}$ & $0,000^{*}$ & $0,000^{*}$ & $0,000^{*}$ & 0,173 \\
\hline
\end{tabular}

* diferença estatisticamente significante $(p<0,05)$.

O gráfico 2 apresenta uma visão geral do comportamento dos materiais nas condições estudadas. Os espécimes, para todos os grupos, partiram de valores próximos de mínima permeabilidade, atingiram a máxima permeabilidade (100\%) e tiveram uma redução dos valores em função do tempo. Esta redução foi mais acentuada para os materiais ativos (OXA-GEL, DD-1 e DD-2), os quais apresentaram resistência ao desafio ácido. Para o agente PLACEBO e a ÁGUA DEIONIZADA também houve uma redução dos valores de permeabilidade, entretanto, essa redução não representou uma resistência ao desafio ácido, retornando-se aos índices próximos da máxima permeabilidade. 
GRÁFICO 2 - COMPORTAMENTO DOS MATERIAIS NAS CONDIÇÕES ESTUDADAS.
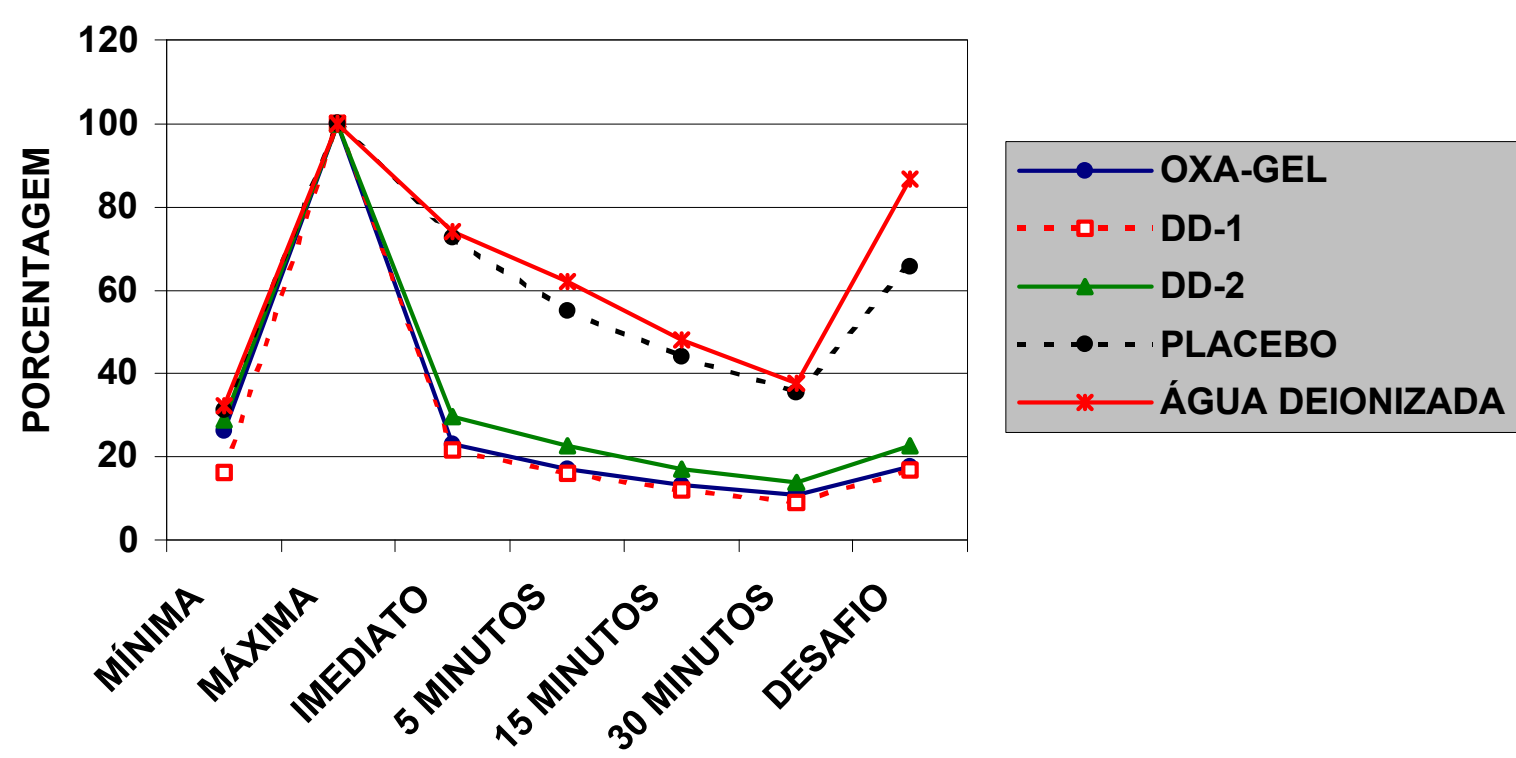


\section{Discussão}

A dentina é um tecido conjuntivo mineralizado composto por células e uma matriz extra-celular, apresentando uma estrutura tubular que se estende por todo tecido, com média de 30.000 túbulos por milímetro quadrado, e esta característica é consequência direta da permeabilidade dentinária ${ }^{78}$.

A teoria hidrodinâmica da dentina sensível baseia-se na premissa de que a movimentação do fluido dentinário no interior dos túbulos, induzida por estímulos na superfície dentinária, é responsável pela ativação indireta de nervos mecanorreceptores próximos à polpa e o surgimento da sensação dolorosa. Uma comprovação desta teoria é que o bloqueio mecânico dos túbulos diminui a movimentação do fluido e a permeabilidade da dentina e consequentemente a hiperestesia dentinária ${ }^{40}$. De acordo com WICHGERS; $\mathrm{EMERT}^{79}$, um tratamento efetivo para a hiperestesia dentinária seria, portanto, a obliteração dos túbulos a fim de reduzir ou inibir o movimento dos fluidos no seu interior e a permeabilidade da dentina.

Há dois mecanismos responsáveis pela passagem de substâncias pela dentina: a difusão e a filtração. A difusão é um processo pelo qual o transporte de substâncias é feito de uma área de alta concentração para uma área de baixa concentração. Na difusão não há movimentação do fluido, mas somente deslocamento molecular. Na filtração, a movimentação do fluido ocorre de uma área de maior pressão hidrostática para uma área de menor pressão ${ }^{42}$. 
A difusão de substâncias pela dentina é proporcional à área dentinária disponível e ao gradiente de concentração da solução. A área disponível para difusão na dentina é determinada pela densidade dos túbulos dentinários e pelo diâmetro dos túbulos, e ambos os valores variam de acordo com a região dentinária em que se atua, sendo maior na região próxima à polpa. A área real de superfície de difusão é o resultado do produto da densidade dos túbulos pela área de cada túbulo. Esta área, em média, pode variar de 1 a 22\% da junção amelodentinária até a região mais próxima à polpa ${ }^{38}$.

É muito importante distinguir transporte de materiais por difusão e filtração. A difusão varia com o quadrado do raio, desde que a área de secção do túbulo é $\pi r^{2}$. Ela ocorre de áreas de alta concentração para áreas de baixa concentração e durante a difusão a concentração de substâncias é dissipada ao longo da distância. Na filtração não ocorre mudança na concentração de substâncias dissolvidas no fluido, porque o fluido e tudo que nele está dissolvido é movimentado de um lado para outro. A força que movimenta é a pressão, que é dissipada pela distância. O transporte pela dentina por filtração varia com a quarta potência do raio. Deste modo, a filtração é mais sensível à obstrução de túbulos que a difusão ${ }^{38}$. Trabalhos conduzidos por MERCHANT; LIVINGSTON; PASHLEY ${ }^{27}$, comparando a filtração com a difusão, observaram que a filtração proporciona uma passagem de iodo radioativo através da smear layer duas vezes maior que a difusão. Após a remoção da smear layer a filtração foi aumentada em trinta e duas vezes em relação a difusão, mostrando que além de desobstruir os túbulos, o condicionamento ácido facilita mais a filtração que a difusão. 
Os estudos quantitativos da permeabilidade dentinária, aqui realizados, envolvem a medição da condutividade hidráulica da dentina, que representa a filtração de líquidos através dos túbulos dentinários sob uma determinada pressão ${ }^{39}$. De acordo com a lei de Pouesille-Hagen a condutividade hidráulica da dentina é proporcional ao raio dos túbulos elevado à quarta potência, e desta forma, pequenas reduções no diâmetro dos túbulos reduzirão grandemente a filtração de líquidos. Isto pode explicar o sucesso do tratamento da hiperestesia dentinária com o uso de agentes terapêuticos que agem através da oclusão de túbulos ${ }^{41}$.

A realização de estudos laboratoriais envolvendo 0 mecanismo de ação dos agentes utilizados na hiperestesia dentinária requer um cuidado especial devido à susceptibilidade a que o substrato dentinário encontra-se exposto. Com base nestes argumentos será discutido a seguir a metodologia utilizada e os resultados encontrados no experimento.

\section{1- Da Metodologia:}

Os dentes utilizados para o estudo foram terceiros molares humanos, hígidos, de preferência não irrompidos na cavidade bucal, para evitar que a formação fisiológica de esclerose dentinária dos dentes em função provocasse uma redução natural da permeabilidade da dentina. A solução utilizada para o armazenamento dos dentes foi criteriosamente selecionada para a melhor preservação de seu estado natural através da utilização de agentes anti-fúngicos, antibióticos e anti-enzimáticos, e é composta de 100mM de azido de sódio, 50mM de 
benzamidine $\mathrm{HCl}$ e $10 \mathrm{mM}$ de $\mathrm{N}$-etil maleimide. De acordo com GOODIS; MARSHALL; WHITE ${ }^{16}$ e GOODIS et al. ${ }^{17}$ o tipo de solução utilizada interfere na permeabilidade dentinária, pois encontraram grande variação da permeabilidade dentinária e da resistência adesiva em função das soluções de armazenamento (Etanol, Formalina, Timol e Água destilada). Entretanto HILTON ${ }^{20}$ afirma que a solução de armazenamento não tem influência significativa nos estudos de adesão. CAMPS et al. ${ }^{8}$, em 1994, compararam o efeito do armazenamento de dentes na condutividade hidráulica da dentina, e os resultados mostraram que os dentes criopreservados apresentaram valores de condutividade hidráulica ligeiramente maiores, embora não estatisticamente significantes, que os dentes armazenados em solução salina tamponada por fosfato a $4^{\circ} \mathrm{C}$.

GOODIS; MARSHALL; WHITE ${ }^{16}$ e GOODIS et al. ${ }^{17}$ afirmam que o tempo de armazenamento prolongado dos dentes reduz a permeabilidade dentinária. Por outro lado, OUTHWAITE; LIVINGSTON; PASHLEY ${ }^{36}$ são unânimes em afirmar que o tempo pós-extração tem apenas um pequeno efeito sobre a medição da condutividade hidráulica da dentina in vitro. A despeito dessas afirmativas estabeleceu-se o tempo máximo de seis meses para a utilização dos dentes.

A literatura dá ênfase a dois métodos de preparação de espécimes para o estudo da condutividade hidráulica da dentina. O primeiro deles emprega para a realização de testes desta natureza discos de dentina $^{8,9,10,19,21,27,29,33,36,47,49,50,52,53,56,5859,60,64,65,71}$, e o outro emprega segmentos de coroas $^{16,17,25,2646,51,65,75,84}$. PASHLEY ${ }^{41}$ afirma que os discos de dentina são muito utilizados nos estudos de permeabilidade dentinária devido à uniformidade de 
espessura que proporcionam, a possibilidade de um bom acabamento dos espécimes, além de permitirem a delimitação da área de superfície a ser testada através do uso de uma câmara de filtração. GILLAM; MORDAN; NEWMAN ${ }^{15}$ e MORDAN; BARBER; GILLAM ${ }^{33}$ preconizam a utilização dos discos de dentina, pois constituem um modelo útil para examinar e testar o potencial de ação dos agentes anti-hiperestésicos in vitro. Desta forma, os espécimes escolhidos no presente trabalho eram discos de dentina devido às vantagens citadas, e também porque possibilitavam menor variabilidade anatômica regional.

Os discos de dentina foram obtidos pelo seccionamento transversal da coroa dentária em duas regiões, uma acima da projeção dos cornos pulpares e outra abaixo da junção amelodentinária oclusal, de forma a constituírem discos com a região central composta exclusivamente por dentina. De fato, esta constituiu-se numa das etapas mais importantes na obtenção e padronização dos espécimes, uma vez que resíduos do esmalte, decorrentes da extensão pulpar das cicatrículas e fissuras, ou áreas correspondentes aos cornos pulpares poderiam, respectivamente, reduzir de forma significativa a filtração de fluidos pela dentina ou exacerbá-la, de modo a comprometer os cálculos da condutividade hidráulica. Espécimes com estas características foram obtidos através de seccionamentos com disco de diamante conforme descrito em material e métodos com base nas observações de diferentes autores ${ }^{10,29,47,49,52,56,65}$. Outros autores, entretanto, obtinham os espécimes através da redução inicial da porção oclusal coronária com brocas e seccionamento com disco de diamante montado em peça de mão $8,9,19,27,36,48,53,58,59,64,71$. Deu-se preferência ao uso de discos diamantados montados em aparelhos específicos devido a melhor padronização de superfície 
cortada e facilidade de obtenção dos espécimes. A eficiência desse procedimento era comprovada quando se examinava os espécimes em lupa estereoscópica, com aumento de 30X, para a detecção da eventual presença dos detalhes anatômicos citados acima, no momento em que apreciava-se a definitiva regularização da superfície seccionada.

Objetivando uma homogeneidade da amostra realizou-se uma previsão dos índices iniciais de filtração para todos os espécimes. Tal procedimento garantiu a utilização de discos de dentina com índices de filtração variando de 10 a $30 \mu \mathrm{l} / \mathrm{min} . . \mathrm{E}$, desta forma, possibilitou a diminuição da interferência de variações anatômicas que ocorre de dente para dente na real interpretação da redução de filtração produzida pelos materiais testados.

No que diz respeito ao dispositivo utilizado para a medição da condutividade hidráulica da dentina deve-se ressaltar que o processo de filtração a que os espécimes foram submetidos requer a utilização de uma pressão determinada para a movimentação do sistema e posterior mensuração da permeabilidade dentinária. O líquido sob pressão movimenta uma microbolha situada na micropipeta durante um determinado espaço de tempo. Como o dispositivo apresenta seus componentes interligados o deslocamento linear realizado pela microbolha é convertido em deslocamento de volume no interior do disco de dentina. A pressão utilizada nesse estudo foi de $703,1 \mathrm{cmH}_{2} \mathrm{O}$ (10p.s.i.), como preconizada por GOODIS; MARSHALL; WHITE ${ }^{16}$, KOUTSI et al. ${ }^{25}$ e SIMPSON et al. ${ }^{75}$. A grande maioria dos estudos utiliza para os testes in vitro, pressões bem maiores que a pressão pulpar fisiológica $\left( \pm 14 \mathrm{cmH}_{2} \mathrm{O}\right)$ para permitir maior rapidez de leitura $8,9,19,27,47,53,56,59,64,70,71$. Os experimentos conduzidos com pressão reduzida 
apresentam como dificuldade a demora da leitura e o cansaço para o operador, pois a bolha movimentar-se-á muito lentamente ${ }^{36,49,58}$. Os estudos realizados com pressão fisiológica devem, de preferência, ser conduzidos com um dispositivo apropriado (FLODEC), que através de um sistema acoplado a um microcomputador permite a rápida mensuração de deslocamentos na ordem de micrômetros, o que seria impossível para a percepção do olho humano ${ }^{11,66,84}$.

REEDER et al. $^{71}$ em 1978 demonstraram que o aumento gradual da pressão $\left(60,120\right.$ e $\left.240 \mathrm{cmH}_{2} \mathrm{O}\right)$ proporciona um crescimento linear nos índices de filtração tanto para discos não condicionados quanto para discos condicionados. Estudos conduzidos por CAMPS et al. ${ }^{10}$ relatam que a variação da pressão utilizada e o tempo de aplicação da pressão, pode, de certa maneira, alterar a condutividade hidráulica da dentina. Em altas pressões ocorre um aumento da resistência intra-tubular através da compressão do conteúdo interno contra as paredes dos túbulos, reduzindo os valores da condutividade hidráulica. Esta redução de valores pode ser ainda maior quando o tempo de medição de filtração é aumentado de dez para cento e oitenta minutos. Com o uso de pressão fisiológica o conteúdo tubular não é afetado e não ocorre alteração da condutividade em função do tempo, e os resultados são mais próximos da realidade (condições in vivo). Os autores indicam o uso de pressões reduzidas, mas alertam para a necessidade de escolha de um dispositivo com maior precisão para determinar pequenos deslocamentos. Acrescentam ainda que os resultados podem explicar, também, a influência da solução de armazenamento nos estudos envolvendo dentina, pois se ocorrer modificação do conteúdo tubular por fixação, hidrólise, desmineralização ou outros fenômenos, a permeabilidade dentinária não se comportará normalmente 
diante uma determinada aplicação de pressão ou por tempos prolongados de armazenamento. Devido a estes fatores é recomendada a utilização de filtração de hipoclorito de sódio $(\mathrm{NaOCl})$ para remover resíduos de matéria orgânica no interior dos túbulos antes da medição da condutividade hidráulica da dentina, reduzindo a interferência da pressão e do tempo de sua aplicação nessas medições.

Um grande avanço nos estudos de permeabilidade dentinária deveu-se ao desenvolvimento de um dispositivo (câmara de filtração), que permite a adaptação de fragmentos de dentina no seu interior, limitando dois espaços independentes com áreas padronizadas, possibilitando a mensuração da passagem de líquidos ou outras substâncias através dos espécimes ${ }^{37}$. A utilização da câmara de filtração permite, assim, a padronização de variáveis importantes, tais como a espessura dos espécimes, a área de superfície e a pressão aplicada, proporcionando melhor compreensão dos fenômenos que envolvem a permeabilidade dentinária ${ }^{42}$. A partir desta metodologia, inúmeros trabalhos surgiram com conclusões precisas para o suporte da movimentação de fluidos pela dentina $a^{8,9,10,19,27,29,36,47,48,49,52,53,56,58,59,60,64,71}$. Dentre essas conclusões, estabeleceuse que a movimentação de fluidos ou filtração é função direta da aplicação de pressão, ou seja, na ausência de pressão não há filtração de fluidos, e o aumento da pressão provoca também um aumento linear da filtração; o condicionamento ácido de discos de dentina eleva os níveis de filtração em trinta e duas vezes em comparação com os discos não condicionados e que a permeabilidade é inversamente proporcional à espessura de dentina e diretamente proporcional à área de superfície ${ }^{36,60,71}$. 
PASHLEY et al. ${ }^{65}$ demonstraram a variabilidade regional da permeabilidade dentinária, tanto qualitativamente com a utilização de corantes quanto quantitativamente pela determinação da condutividade hidráulica de discos de dentina. Os resultados comprovaram que a variabilidade regional é uma característica inerente da permeabilidade dentinária e que não pode ser explicada somente pela espessura de dentina ou pelo comprimento dos túbulos, mas sim, pelo maior diâmetro e número de túbulos em regiões próximas aos cornos pulpares. Isto faz com que nos estudos de condutividade hidráulica de discos de dentina seja utilizada a maior área de dentina possível para compensar estas diferenças regionais e que os espécimes sejam obtidos em regiões próximas à polpa. Nesse experimento dava-se preferência, sempre que as condições anatômicas dos espécimes permitissem, a utilização de uma área exposta de dentina de $0,282 \mathrm{~cm}^{2}$ em detrimento da área de $0,178 \mathrm{~cm}^{2}$.

Para facilitar a interpretação dos dados referentes ao potencial de ação dos agentes anti-hiperestésicos e permitir a utilização de cada espécime como seu próprio controle, é comum a determinação da mínima e da máxima permeabilidade dos discos de dentina. Esses valores funcionam como parâmetros para avaliar a efetividade ou não dos agentes e terapias empregados ${ }^{41}$. A mínima permeabilidade dos espécimes é determinada pela presença de smear layer ocluindo os túbulos, permitindo a mínima passagem de fluidos pela dentina conforme os achados de PASHLEY; LIVINGSTON; GREENHILL ${ }^{53}$. Esses autores observaram que a alteração de superfície proporcionada pela smear layer foi responsável por $86 \%$ da resistência total da movimentação de fluidos no interior da dentina. Contrariamente, a remoção da smear layer por desmineralização provoca 
um aumento significante na filtração de fluidos pela dentina da ordem de trinta e duas vezes ${ }^{71}$ determinando a máxima permeabilidade do espécime. Com esses referenciais torna-se mais fácil interpretar as medições da permeabilidade dentinária quando do uso de agentes que atuam por obliteração de túbulos ${ }^{41}$.

\section{2- Dos Resultados:}

Os resultados obtidos para todos os espécimes nas condições de tempo estudadas, expressos em condutividade hidráulica $\left(\mu l . \mathrm{cm}^{-2}\right.$. $\mathrm{min}^{-1} . \mathrm{cmH}_{2} \mathrm{O}^{-1}$ ), foram transformados em porcentagem com o objetivo de diminuir a variabilidade biológica a que o substrato dentinário encontra-se sujeito em cada disco, como a espessura de esmalte e o volume da câmara pulpar ${ }^{19}$.

A literatura relata o mecanismo de ação do oxalato de potássio na redução da hiperestesia dentinária através do bloqueio ou redução do lúmen dos túbulos dentinários, tanto em estudos in vitro ${ }^{19,21,32,47,51,60,64,70,74,80}$ quanto in vivo ${ }^{12,13,23,34,77}$. Os dados do trabalho de PASHLEY; LIVINGSTON; GREENHILL ${ }^{53}$ sugerem que a alteração de superfície representada pela oclusão dos túbulos causada na presença de smear layer pode ratificar a eficiência dos agentes terapêuticos à base de oxalato de potássio, pois a oclusão dos túbulos causada por estes agentes, similarmente à smear layer, reduz a movimentação de fluidos através da dentina e consequentemente reduz a hiperestesia dentinária. Os agentes à base de oxalato de potássio atuam, então, por obliteração dos túbulos através da formação e deposição de cristais de oxalato de cálcio em presença de meio ácido. Esses cristais são produtos da reação dos radicais ácidos do oxalato de potássio 
com o cálcio presente no fluido dentinário e atuam tanto na superfície quanto no interior dos túbulos ${ }^{80}$.

A despeito das observações de YAMAMOTO et al. $^{80}$, na presente investigação a filtração foi realizada com água deionizada, desprovida de qualquer componente mineral que pudesse reagir com o oxalato de potássio. Por outro lado, a desmineralização realizada com o EDTA para a obtenção da permeabilidade máxima reduz consideravelmente as reservas de íons cálcio na superfície da dentina, promovendo uma condição local de menor reatividade com géis anti-hiperestésicos. Esta situação pode explicar a reatividade dos géis experimentais com a dentina em função de seu pH, como será descrito mais adiante. Essas observações são corroboradas também, por trabalhos desenvolvidos no Departamento de Dentística da Faculdade de Odontologia de Bauru usando microscopia eletrônica de varredura observando a deposição de cristais na embocadura dos túbulos dentinários e no interior dos mesmos, locais em que se espera ocorrer maior disponibilidade de íons à disposição da reação com o oxalato de potássio. Se comparados com a aplicação clínica, as medições realizadas nesse experimento representam um teste severo da capacidade reativa dos agentes à base de oxalato de potássio com o substrato dentinário porque utilizou-se a água deionizada como agente filtrante e desmineralizou-se previamente a dentina para a obtenção da permeabilidade máxima.

Os estudiosos são unânimes em afirmar que a ocorrência de hiperestesia dentinária está diretamente relacionada com a movimentação de fluidos através da dentina exposta ao meio bucal. Essa dentina sensível apresenta túbulos abertos, como confirmados por ABSI; ADDY; ADAMS ${ }^{1}$, YOSHIYAMA et al. $1989^{82}$ e 
YOSHIYAMA et al. $1990^{83}$. Esses autores, utilizando réplicas in vivo e biópsias de dentina hiperestésica, observaram que nessas regiões, $75 \%$ dos túbulos dentinários encontravam-se abertos, enquanto esse percentual é aproximadamente três vezes menor nas regiões menos sensíveis da mesma superfície dentinária exposta. Essas observações estabelecem uma definitiva relação da abertura dos túbulos com a ocorrência de hiperestesia dentinária, que dá suporte a teoria hidrodinâmica. YOSHIYAMA; SUGE; EBISU ${ }^{81}$, em 1996, utilizando a mesma metodologia dos trabalhos anteriores, relataram que as biópsias de regiões sensíveis apresentaram uma estrutura oca e tubular em $75,8 \%$ dos túbulos dentinários. Nas biópsias de áreas não sensíveis, no mesmo dente, essas estruturas foram vistas somente em $20,4 \%$ dos túbulos. Os autores afirmam que a estrutura tubular encontrada nas regiões sensíveis são responsabilizadas por dificultarem a obliteração espontânea dos túbulos, mantendo desta forma a hiperestesia dentinária.

SENA $^{73}$, enfatiza a importância dos testes laboratoriais no estudo da hiperestesia dentinária devido a fatores, tais como a dificuldade do manejo clínico, problemas na seleção de pacientes, diagnóstico diferencial e a resposta ao efeito placebo. O autor conclui que os métodos laboratoriais na medição da permeabilidade dentinária são, portanto, de grande valia, uma vez que a hiperestesia é considerada um fenômeno sensorial complexo, dependente de fatores fisiológicos e emocionais não completamente definidos. Entretanto, GILLAM; MORDAN; NEWMAN ${ }^{15}$, afirmam que embora os estudos laboratoriais empregando discos de dentina constituam um método útil para examinar o potencial dos agentes usados no tratamento da hiperestesia dentinária, é necessário ter em mente que a extrapolação clínica de resultados in vitro deve ser feita com cautela. 
A redução da permeabilidade dentinária proporcionada pelos agentes à base de oxalato de potássio in vitro relatada na literatura é de, 95 a $98 \%^{19,21,32,46,47,64,77}$, o presente estudo apresentou uma redução da permeabilidade dentinária imediata, em média de, $75 \%$ para todos os materiais ativos.

Uma das propostas deste trabalho foi estabelecer a eventual interferência do sistema de medição da condutividade hidráulica da dentina na interpretação da real ação dos agentes anti-hiperestésicos por obstrução dos canalículos dentinários. A primeira abordagem dos resultados, como apresentada na tabela 3, mostra que as médias dos valores de condutividade hidráulica para os materiais ativos, no período imediato, demonstra uma efetividade obstrutiva muito próxima daquela proporcionada pela smear layer. Esta redução na permeabilidade gira em torno de $75 \%$ para todos esses materiais e smear layer. A interpretação desses resultados indica que essas drogas são capazes de bloquear a movimentação de fluidos através da dentina em índices semelhantes ao da condição natural considerada mais conveniente para a proteção da superfície dentinária exposta $^{53}$. Essa mesma tabela 3 dá uma visão de redução espontânea da permeabilidade da dentina relativa aos intervalos de tempo estudados. É importante lembrar que para a sequência das medições da permeabilidade em função do tempo, os materiais foram aplicados por três minutos e removidos por lavagem completa da superfície dos espécimes, conforme recomenda a técnica de aplicação desses materiais. A redução da permeabilidade notada ainda que não abordada estatisticamente, até o presente momento, descarta a possibilidade de ação progressiva dos materiais testados, já que estes foram removidos, como descrito. 
Fica claro, portanto, que a redução da permeabilidade pode progredir passivamente pela simples filtração da água deionizada utilizada para a movimentação do sistema.

Há algumas prováveis razões para a redução passiva da filtração. Uma delas, é a presença de resíduos no conteúdo intra-canalicular que remanescem mesmo após a obtenção dos discos de dentina. Esses resíduos seriam fragmentos citoplasmáticos do prolongamento odontoblástico ou partículas residuais que fazem parte do conteúdo original intra-tubular ${ }^{78,80,81}$. Outra possibilidade é a permanência de resíduos de smear plugs não completamente removidos pelo ácido a despeito da intenção de completa limpeza da superfície dos discos com EDTA imediatamente antes da aplicação dos agentes. A literatura demonstra que o emprego do EDTA como agente condicionador remove a smear layer e promove a ampliação da abertura dos túbulos, tanto in vivo quanto in vitro ${ }^{28}$. Entretanto, podese suspeitar de que resíduos microscópicos remanescentes no interior dos túbulos que não teriam qualquer ação individual no bloqueio da filtração, com a contínua passagem de fluido através da dentina podem sofrer deslocamentos e se concentrarem em regiões de menor diâmetro, proporcionando um efeito obstrutivo sensível ao processo de medição da filtração.

Essa possibilidade, pode explicar o efeito do tempo de aplicação da pressão na redução passiva da permeabilidade dentinária tanto para os agentes ativos quanto para os não ativos. É interessante observar que esse efeito é mais notado nos agentes não ativos do que para as drogas ativas, pois as mesmas já proporcionam uma grande redução imediata, suficiente para minimizar o efeito do tempo sobre a redução da filtração. Por outro lado, os agentes não ativos por não proporcionarem obstrução mecânica imediata dos túbulos, acusam mais 
bruscamente a redução da filtração ao longo dos intervalos de tempo, decorrente de pequenos deslocamentos de partículas no seu interior. De fato, não foram observadas diferenças estatisticamente significantes entre os índices de filtração imediato e após cinco minutos para os agentes ativos. Entretanto, os índices de filtração passaram a ter diferenças estatísticas quando se estabeleceram as comparações entre os resultados imediato e após quinze e trinta minutos, exceto para o DD-1, onde não foi notada significância entre os resultados do período imediato e quinze minutos (tabela 6). No que diz respeito à composição dos materiais ativos (OXA-GEL, DD-1 e DD-2) utilizados para esse estudo, a carboximetilcelulose é um espessante inerte que foi empregado para a obtenção dos géis de Oxa-Gel e do agente experimental DD-1. Este material apresenta um pH originalmente neutro, promovendo uma ligeira elevação do pH da solução de oxalato de potássio monohidratado, cuja acidez é ajustada para 2 no momento da preparação da solução. Quando combinadas a solução e a carboximetilcelulose, o gel obtido tem elevação do $\mathrm{pH}$ para 4. Teoricamente, a reatividade destas formulações com a dentina é regulada pelo $\mathrm{pH}$ ácido do medicamento, que somada à natural afinidade do potássio com o cálcio e o fosfato promove a precipitação de cristais sobre a dentina e no interior dos túbulos dentinários. Entretanto, o espessante empregado para o agente experimental DD-2 foi o carbopol. Este material proporciona um gel de oxalato de potássio que mantém o $\mathrm{pH}$ original da solução, em torno de 2, e uma possível maior reatividade deste com a dentina devido sua maior acidez.

Nesse estudo utilizou-se um gel inativo empregado como controle dos agentes ativos e a água deionizada filtrada livremente ao longo dos 
intervalos de tempo, nos quais se faziam os registros de filtração, servindo de controle do sistema. Tal procedimento objetivava considerar um eventual arrefecimento espontâneo do processo de filtração com o passar do tempo, observando a interferência do próprio dispositivo na redução da permeabilidade dentinária.

A medição da condutividade hidráulica da dentina para os espécimes desse grupo mostrou uma redução imediata em torno de $25 \%$, contrariamente ao trabalho conduzido por GREENHILL; PASHLEY ${ }^{19}$ que usaram a água destilada e obtiveram uma redução média da condutividade hidráulica de apenas $0,2 \%$. Entretanto, cabe ressaltar que a pressão utilizada no seguinte trabalho foi cerca de três vezes menor que a utilizada no presente estudo. De acordo com CAMPS et al. ${ }^{10}$ esta redução dos valores da condutividade hidráulica em função do tempo pode ser devido a utilização de pressões elevadas, como a que nós empregamos $\left(703,1 \mathrm{cmH}_{2} \mathrm{O}\right)$, ou a fatores relativos ao tempo e solução de armazenamento. Ressalta-se ainda que esta eventual redução também possa ser fruto de impurezas presentes no interior dos capilares de polietileno, utilizados como elo de união entre os componentes do dispositivo utilizado para a medição da condutividade hidráulica, embora tenha se tomado todo cuidado nesta etapa através de verificações periódicas do reservatório de água deionizada.

O agente placebo apresentou uma redução similar à redução da água deionizada, não mostrando, qualquer potencial adicional de obstrução quantitativa, pois os valores da condutividade hidráulica de ambos os grupos não apresentaram diferenças estatisticamente significantes. 
Após a realização de todas as medições da condutividade hidráulica da dentina em função dos intervalos de tempo propostos, todos os espécimes foram submetidos a um meio ácido para comprovação da eficiência dos tratamentos executados. Este procedimento era realizado pela aplicação de ácido cítrico a $6 \% \mathrm{pH} 2$ por um minuto, e de acordo com a tabela 7, os agentes ativos OxaGel, DD-1 e DD-2 mostraram-se resistentes ao meio ácido, o que denota a efetividade do tratamento através do bloqueio dos túbulos e permanência da redução dos valores de permeabilidade. Estes valores ficaram próximos aos da mínima permeabilidade estabelecida pela smear layer. Diferentemente, o agente placebo e a simples filtração de água deionizada através dos discos de dentina mostraram-se sensíveis ao tratamento ácido, uma vez que os valores de redução apresentados em função do tempo foram elevados a níveis próximos aos da máxima permeabilidade. Isto comprova a ineficiência do agente placebo em reduzir a permeabilidade da dentina in vitro, e a influência natural do sistema utilizado para medição da condutividade hidráulica na redução dos valores de permeabilidade.

A análise comparativa dos índices de filtração obtidos com a água deionizada e os géis estudados mostra, então, que os resultados devem ser interpretados com critério, entendendo que a ação efetiva dos agentes obstrutores dos túbulos dentinários é o somatório de sua reatividade com a dentina e precipitação de cristais e o efeito obstrutivo de partículas provocado pelo próprio sistema. 


\section{ConClusões}

Com base nos resultados da análise estatística aplicada, pode-se concluir que:

1) Os agentes anti-hiperestésicos estudados mostraram-se efetivos e semelhantes entre si na redução da permeabilidade dos discos de dentina, independentemente dos períodos de tempo estudados;

2). Os controles utilizados (Placebo e Água deionizada) foram igualmente sensíveis às variáveis de tempo estudadas;

3) O sistema interfere nos resultados de filtração em função do tempo, pois há uma tendência de redução dos valores de filtração quando o sistema flui livremente pelos intervalos de tempo testados;

4) Considerando que, nesse trabalho, o sistema produziu uma redução imediata de $25 \%$ na filtração, pode-se entender que todo agente com proposta de obstrução dos canalículos dentinários, só terá efeito positivo se suplantar o efeito obstrutivo do próprio sistema. 
ANEXOS 
ANEXO 1 - Resultados individuais do grupo I (OXA-GEL) para cada espécime nas condições testadas

\begin{tabular}{cccccccc}
\hline ESPÉCIME & MÍNIMA & MÁXIMA & IMEDIATO & 5 MIN. & 15 MIN. & 30 MIN. & DESAFIO \\
\hline 1 & 5,19 & 100 & 13,41 & 9,06 & 5,56 & 4,11 & 6,76 \\
2 & 24,3 & 100 & 20,39 & 18,99 & 19,27 & 17,88 & 19,83 \\
3 & 10,81 & 100 & 21,79 & 14,7 & 10,14 & 10,81 & 14,86 \\
4 & 5,81 & 100 & 15,41 & 11,34 & 8,72 & 7,56 & 12,79 \\
5 & 32,21 & 100 & 17,11 & 11,41 & 9,4 & 6,71 & 17,45 \\
6 & 11,19 & 100 & 43,57 & 32,14 & 20,71 & 12,14 & 30 \\
7 & 4,74 & 100 & 5,69 & 3,32 & 2,28 & 1,9 & 3,98 \\
8 & 36,29 & 100 & 20,16 & 12,9 & 11,29 & 9,68 & 17,74 \\
9 & 63,14 & 100 & 34,53 & 28,6 & 24,58 & 20,97 & 24,15 \\
10 & 67,66 & 100 & 38,19 & 28,95 & 22,62 & 18,58 & 28,75 \\
\hline
\end{tabular}


ANEXO 2 - Resultados individuais do grupo II (DD-1) para cada espécime nas condições testadas

\begin{tabular}{cccccccc}
\hline ESPÉCIME & MÍNIMA & MÁXIMA & IMEDIATO & 5 MIN. & 15 MIN. & 30 MIN. & DESAFIO \\
\hline 1 & 1,4 & 100 & 5,07 & 2,97 & 1,57 & 1,05 & 6,29 \\
2 & 1,93 & 100 & 12,11 & 8,42 & 7,89 & 5,79 & 15,26 \\
3 & 73,59 & 100 & 26,41 & 21,48 & 16,55 & 13,38 & 16,9 \\
4 & 1,93 & 100 & 25,74 & 19,35 & 14,58 & 11,01 & 21,28 \\
5 & 3,4 & 100 & 22,6 & 16,8 & 12,6 & 8,8 & 14 \\
6 & 61,36 & 100 & 34,09 & 27,27 & 22,73 & 15,91 & 29,55 \\
7 & 6,01 & 100 & 36,82 & 26,36 & 17,64 & 13,18 & 22,09 \\
8 & 5,44 & 100 & 15,48 & 10,46 & 8,37 & 7,95 & 17,57 \\
9 & 5,37 & 100 & 24,79 & 18,18 & 11,98 & 9,92 & 14,05 \\
10 & 1,75 & 100 & 14,47 & 9,65 & 7,02 & 3,95 & 10,09 \\
\hline
\end{tabular}


ANEXO 3 - Resultados individuais do grupo III (DD-2) para cada espécime nas condições testadas

\begin{tabular}{cccccccc}
\hline ESPÉCIME & MÍNIMA & MÁXIMA & IMEDIATO & 5 MIN. & 15 MIN. & 30 MIN. & DESAFIO \\
\hline 1 & 14,29 & 100 & 38,1 & 23,81 & 19,05 & 19,05 & 38,1 \\
2 & 78,57 & 100 & 45,33 & 38,19 & 30,22 & 23,9 & 39,84 \\
3 & 7,6 & 100 & 13,01 & 8,77 & 6,73 & 5,41 & 8,48 \\
4 & 76,44 & 100 & 28,37 & 23,56 & 18,99 & 15,38 & 22,6 \\
5 & 30,23 & 100 & 39,87 & 34,08 & 23,79 & 17,36 & 21,86 \\
6 & 2,09 & 100 & 40,87 & 30 & 24,38 & 19,33 & 17,45 \\
7 & 4,8 & 100 & 8,9 & 10 & 3,3 & 2,9 & 6,6 \\
8 & 50,88 & 100 & 38,6 & 28,75 & 22,81 & 17,76 & 29,82 \\
9 & 3,31 & 100 & 19,89 & 14,09 & 9,94 & 7,18 & 7,73 \\
10 & 20,85 & 100 & 24,17 & 15,64 & 10,9 & 9,48 & 33,65 \\
\hline
\end{tabular}


ANEXO 4 - Resultados individuais do grupo IV (PLACEBO) para cada espécime nas condições testadas

\begin{tabular}{cccccccc}
\hline ESPÉCIME & MÍNIMA & MÁXIMA & IMEDIATO & 5 MIN. & 15 MIN. & 30 MIN. & DESAFIO \\
\hline 1 & 29,47 & 100 & 42,11 & 32,63 & 26,32 & 25,26 & 44,21 \\
2 & 52,17 & 100 & 60,87 & 36,96 & 29,35 & 25 & 33,7 \\
3 & 21,93 & 100 & 63,16 & 47,37 & 40,35 & 33,33 & 58,77 \\
4 & 25,24 & 100 & 84,47 & 46,6 & 35,92 & 29,13 & 76,21 \\
5 & 19,72 & 100 & 82,39 & 65,49 & 45,77 & 32,39 & 61,97 \\
6 & 72,9 & 100 & 84,11 & 64,49 & 47,66 & 34,58 & 43,93 \\
7 & 37,7 & 100 & 81,97 & 65,57 & 65,57 & 50,82 & 118,03 \\
8 & 7,18 & 100 & 60,06 & 55,17 & 44,54 & 35,63 & 58,05 \\
9 & 5,13 & 100 & 84,19 & 72,65 & 56,41 & 44,44 & 50 \\
10 & 40,74 & 100 & 84,26 & 62,96 & 50 & 44,44 & 112,96 \\
\hline
\end{tabular}


ANEXO 5 - Resultados individuais do grupo V (ÁGUA DEIONIZADA) para cada espécime nas condições testadas

\begin{tabular}{cccccccc}
\hline ESPÉCIME & MÍNIMA & MÁXIMA & IMEDIATO & 5 MIN. & 15 MIN. & 30 MIN. & DESAFIO \\
\hline 1 & 29,25 & 100 & 40,82 & 34,69 & 27,89 & 24,49 & 79,59 \\
2 & 11,17 & 100 & 59,9 & 43,15 & 26,9 & 17,77 & 53,3 \\
3 & 14,92 & 100 & 77,35 & 59,12 & 41,16 & 29,56 & 46,41 \\
4 & 72,97 & 100 & 87,39 & 74,77 & 57,66 & 41,89 & 73,87 \\
5 & 15,85 & 100 & 86,59 & 81,71 & 68,29 & 62,2 & 219,51 \\
6 & 15,79 & 100 & 71,71 & 62,5 & 53,95 & 46,71 & 131,58 \\
7 & 58,24 & 100 & 82,35 & 65,88 & 52,94 & 44,71 & 60 \\
8 & 66,67 & 100 & 76,67 & 63,81 & 50,95 & 39,52 & 62,38 \\
9 & 16,59 & 100 & 65,45 & 49,77 & 35,68 & 25 & 71,82 \\
10 & 21,64 & 100 & 91,81 & 84,21 & 64,91 & 45,03 & 67,25 \\
\hline
\end{tabular}




\section{REFERÊNCIAS BIBLIOGRÁFICAS}

1- ABSI, E.G.; ADDY, M.; ADAMS, D. Dentine hypersensitivity- the development and evaluation of a replica technique to study sensitive and non-sensitive cervical dentine. J. clin. Periodontol., v.16, n.9, p.190-95, Sept. 1989.

2- ADDY, M.; WEST, N. Etiology, mechanisms, and management of dentine hipersensitivity. Curr. Opinion Periodontol., p.71-77, 1994.

3- BISSADA, N.F. Symptomatology and clinical features of hypersensitive teeth. Archs. Oral Biol., v.39, p.31S-2S, 1994. Supplement.

4- BOWEN, R.L. et al. Smear layer: removal and bonding considerations. Oper. Dent., v.9, p.30-34, 1984. Supplement n.3.

5- BRÄNNSTRÖM, M.; ASTRÖM, A. The hidrodynamics of the dentine; its possible relationship to dentinal pain. Int. dent. J., v.22, n.2, p.219-27, June 1972.

6- BRÄNNSTRÖM, M.; JOHNSON, G. Effect of various conditioners and cleaning agents on prepared dentin surfaces: a scanning electron microscope investigation. J. Prosth. Dent., v.31, n.4, p.422-30, Apr. 1974.

\footnotetext{
* Normas recomendadas para uso no âmbito da Universidade de São Paulo, com base no documento "Referências Bibliográficas: exemplos", emanado do Conselho Supervisor do Sistema Integrado de Bibliotecas da USP.
} 
7- BRÄNNSTRÖM, M.; NORDENVALL, K.J.; GLANTZ, P.O. The effect of EDTAcontaining surface - active solutions on the morphology of prepared dentin: an in vivo study. J. dent. Res., v.59, n.7, p.1127-31, July 1980.

8- CAMPS, J. et al. Influence of tooth cryopreservaation on human dentin permeability, in vitro. Dent. Mater., v.10, n.3, p.210-14, May 1994.

9- CAMPS, J. et al. Influence of concentration and application time of maleic acid on dentin permeability. Dent. Mater., v.11 n.3 ,p.177-81, May 1995.

10- CAMPS, J. et al. Low versus high pressure for in vitro determination of hydraulic condutance of human dentine. Archs. Oral Biol., v.42, n.4, p.293-8, Apr. 1997.

11- CIUCCHI, B. et al. Dentinal fluid dynamics in human teeth, in vivo. J. Endod., v.21, n.4, p.191-4, Apr. 1995.

12- COOLEY, R.L.; SANDOVAL, V.A. Effectiveness of potassium oxalate treatment on dentin hypersensitivity. Gen. Dent., v.37, n.4, p.330-3, July/Aug. 1989.

13- ESTRELA, C. et al. Análise da redução da dor pós-tratamento da hipersensibilidade dentinária. ROBRAC, v.6, n. 17, p.4-9, mar. 1996. 
14- GARBEROGLIO, R.; BRÄNNSTRÖM, M. Scanning electron microscopic investigation of human dentinal tubules. Archs. Oral Biol., v.21, n.6, p.35562, June 1976.

15- GILLAM, D.G.; MORDAN, N.J.; NEWMAN, H.N. The dentin disc surface: a Plausible model for dentin physiology and dentin sensitivity evaluation. Adv. dent. Res., v.11, n.4, p.487-501, Nov. 1997.

16- GOODIS, H.E.; MARSHALL, G.W.; WHITE, J.M. The effects of storage after extraction of the teeth on human dentine permeability in vitro. Archs. Oral Biol., v.36, n.8, p.561-6, Aug. 1991.

17- GOODIS, H.E. et al. Storage effects on dentin permeability and shear bond strengths. Dent. Mater., v.9, n.2, p.79-84, Mar. 1993.

18- GOODIS, H.E. et al. Measurement of fluid flow through laser treated dentine. Archs. Oral Biol., v.39, p.128S, 1994. Supplement.

19- GREENHILL, J.D.; PASHLEY, D.H. The effects of desensitizing agents on the hydraulic condutance of human dentin in vitro. J. dent. Res., v.60, n.3, p.686-98, Mar. 1981. 
20- HILTON, T.J. Can modern restorative procedures and materials reliably seal cavities. In: CONFERENCE ON CRITICAL REVIEWS OF RESTORATIVE QUANDARIES, Banff, 1998. Proceedings. Geneva, Academy of Dental Materials, 1998. p.21-71.

21- JAIN, P. et al. Dentin desensitizing agents: SEM and X-ray microanalysis assessment. Amer.J. Dent., v.10, n.1, p.21-6, Jan. 1997.

22- JOHNSON, G.; OLGART, L.; BRÄNNSTRÖM, M. Outward fluid flow in dentin under a physiologic pressure gradient: experiments in vitro. Oral Surg. Oral Med. Oral Pathol., v.35, n.2, p.238-48, Feb. 1973.

23- KERNS, D.G. et al. Dentinal tubule oclusion and root hypersensitivity. J. Periodontol., v.62, n.7, p.421-8, July 1991.

24- KNIGHT, N. N. et al. Hypersensitive dentin: testing of procedures for mechanical and chemical obliteration of dentinal tubuli. J. Periodontol., v.64, n.5, p.36673, May 1993.

25- KOUTSI, V. et al. The effect of dentin depth on the permeability and ultrastructure of primary molars. Pediatr. Dent., v.16, n.1, p.29-35, Jan./Feb. 1994. 
26- MATTHEWS, W.G.; SHOWMAN, C.D.; PASHLEY, D.H. Air blast-induced evaporative water loss from human dentine, in vitro. Archs. Oral Biol., v.38, n.6, p.517-24, June 1993.

27- MERCHANT, V.A.; LIVINGSTON, M.J.; PASHLEY, D.H. Dentin permeation: comparison of diffusion with filtration. J. dent. Res., v.56, n.10, p.1161-4, Oct. 1977.

28- MEYRON, S.D.; TOBIAS, R.S.; JAKEMAN, K.J. Smear removal agents: a quantitative study in vivo and in vitro. J. Prosth. Dent., v.57, n.2, p.174-9, Feb. 1987.

29- MICHELICH, V.; PASHLEY, D.H.; WHITFORD, G.M. Dentin permeability: a comparison of functional versus anatomical tubular radii. J. dent. Res., v.57, n.11/12, p.1019-24, Nov./Dec. 1978.

30- MJÖR, I.A. Dentin-predentin complex and its permeability: pathology and treatment overview. J. dent. Res., v.64, p.621-7, Apr. 1985. Special issue.

31- MJÖR, I.A. Dentina e polpa. In: MJÖR, I.A.; FEJERSKOV. O. Embriologia e histologia oral humana. São Paulo, Panamericana, 1990. p.90-130. 
32- MONGIORGI, R.; PRATI, C. Mineralogical and crystallographical study of gamacalcium oxalate on dentine surfaces in vitro. Archs. Oral Biol., v.39, p.152S, 1994. Supplement.

33- MORDAN, N.J.; BARBER, P.M.; GILLAM, D.G. The dentine disc. a review of its applicability as a model for in vitro testing of dentine hypersensitivity. J. Oral Rehabil., v.24, n.2, p.148-56, Feb. 1997.

34- MUZZIN, K.B.; JOHNSON, R. Effects of potassium oxalate on dentin hypersensitivity in vivo. J. Periodontol., v.60, n.3, p.151-8, Mar. 1989.

35- ORCHARDSON, R. et al. Dentine hypersensitivity - into the 21st century. Arch. Oral Biol., v.39, p.113S-19S, 1994. Supplement.

36- OUTHWAITE, W.C.; LIVINGSTON, M.J.; PASHLEY, D.H. Effects of changes in surface area, thickness, temperature and post-extraction time on human dentine permeability. Archs. oral Biol., v.21, n.10, p.599-603, Oct. 1976.

37- OUTHWAITE, W.C.; MCKENZIE, D.M.; PASHLEY, D.H. A versatile split-chmber device for studying dentin permeability. J. dent. Res., v.53, n.6, p.1503, Nov./Dec. 1974.

38- PASHLEY, D.H. Smear layer: physiological considerations. Oper. Dent., p.13-29, 1984. Supplement n.3. 
39- PASHLEY, D.H. Dentin-predentin complex and its permeability: physiologic overview. J. dent. Res., v.64, p.613-20, Apr. 1985. Special issue.

40- PASHLEY, D.H. Dentin permeability, dentin sensitivity, and treatment through tubule occlusion. J. Endod., v.12, n.10, p.465-74, Oct. 1986.

41- PASHLEY, D.H. Dentin permeability: theory and pratice. In: SPANGBERG, L.S.W. ed. Experimental endodontics. Flórida, CRC Press, 1990a. p.19-49.

42- PASHLEY, D.H. Mechanism of dentin sensitivity. Dent. Clin. N. Amer., v.34, n.3, p.449-73, July. $1990 b$.

43- PASHLEY, D.H. Dentin permeability and dentin sensitivity. Proc. Finn. dent. Soc., v.88, p.31-7, 1992. Supplement I.

44- PASHLEY, D.H. Dentin sensitivity: theory and treatment. Focus on Adult Oral Health, v.1, n.2, p.1-7, July. 1993.

45- PASHLEY, D.H. Dentin permeability and its role in the pathobiology of dentine sensitivity. Arch. Oral Biol.,v.39, p.73S-80S, 1994. Supplement.

46- PASHLEY, D.H.; DEPEW, D.D. Effects of the smear layer, copalite and oxalate on microleakage. Oper. Dent., v.11, n.3, p.95-102, Summer 1986. 
47- PASHLEY, D.H.; GALLOWAY, S.E. The effects of oxalate treatment on the smear layer of ground surfaces of human dentine. Archs. Oral Biol., v.30, n.10, p.731-7, Oct. 1985.

48- PASHLEY, D.H.; LIVINGSTON, M.J. Effect of molecular size on permeability coeficients in human dentine. Archs. Oral Biol., v.23, n.5. p.391-5, May 1978.

49- PASHLEY, D.H.; MATTHEWS, W.G. The effects of outward forced convective flow on inward diffusion in human dentine in vitro. Archs. Oral Biol., v.38, n.7, p.577-82, July 1993.

50- PASHLEY, D.H.; WHITFORD, G.M. Permeability of human dentine in vitro interpreted from reflection coefficients. Archs. Oral Biol., v.25, n.2, p.141-4, Feb. 1980.

51- PASHLEY, D.H.; ANDRINGA, H.J.; EICHMILLER, F. Effects of ferric and aluminium oxalates on dentin permeability. Am.J. Dent., v.4, n.3, p.123-6, June 1991.

52- PASHLEY, D.H.; KALATHOOR, S.; BURNHAM, D. The effects of calcium hydroxide on dentin permeability. J. dent. Res., v.65, n.3, p.417-20, Mar. 1986. 
53- PASHLEY, D.H.; LINVGSTON, M.J.; GREENHILL, J.D. Regional resistance to fluid flow in human dentine in vitro. Archs. Oral Biol., v.23, n.9, p.807-10, Sept. 1978.

54- PASHLEY, D.H.; LIVINGSTON, M.J.; WHITFORD, G.M. The effect of molecular size on reflection coeficient in human dentine. Archs. Oral Biol., v.24, n.6, p.455-60, June 1979.

55- PASHLEY, D.H.; MICHELICH, V.; KEHL, T. Dentin permeability: effects of smear layer removal. J. Prosthet. Dent., v.46, n.5, p.531-7, Nov. 1981.

56- PASHLEY, D.H.; NELSON, R.; KEPLER, E.E. The effects of plasma and salivary constituents on dentin permeability. J. dent. Res., v.61, n.8, p.978-81, Aug. 1982.

57- PASHLEY, D.H.; NELSON, R.; PASHLEY, E.L. In vivo fluid movement across dentine in the dog. Archs. Oral Biol., v.26, n.9, p.707-10, Sept. 1981.

58- PASHLEY, D.H.; STEWART, F.P.; GALLOWAY, S.E. Effects of air-drying in vitro on human dentin permeability. Archs. Oral Biol., v.29, n.5, p.379-83, May 1984. 
59- PASHLEY, D.H.; THOMPSON, S.M.; STEWART, F.P. Dentin permeability: effects of temperature on hydraulic condutance. J. dent. Res., v.62, n.9, p.956-9, Sept. 1983.

60- PASHLEY, D.H. et al. Effects of the degree of tubule occlusion on the permeabilityof human dentine in vitro. Archs. Oral Biol., v.23, n.12, p.112731, Dec. 1978.

61- PASHLEY, D.H. et al. Comparison of in vitro and in vivo dog dentin permeability. J. dent. Res., v.60, n.3, p.763-8, Mar. 1981.

62- PASHLEY, D.H. et al. Use of dentine-fluid protein concentrations to measure pulp capillary reflection coefficients in dogs. Archs. Oral Biol., v.26, n.9, p.703-6, Sept. 1981.

63- PASHLEY, D.H. et al. The effects of acid etching on the in vivo permeability of dentine in the dog. Archs. Oral Biol., v.28, n.7, p.555-9, July 1983.

64- PASHLEY, D.H. et al. Dentin permeability- effects of desensitizing dentifrices in vitro. J. Periodontol., v.55, n.9, p.522-5, Sept. 1984.

65- PASHLEY, D.H. et al. Regional variability in the permeability of human dentine. Archs. Oral Biol., v.32, n.7, p.519-23, July 1987. 
66- PASHLEY, D.H. et al. Fluid shifts across human dentine in vitro in response to hydodynamic stimuli. Archs. Oral Biol., v.41, n.11, p.1065-72, Nov. 1996.

67- PEREIRA, J. C. Hiperstesia dentinária - aspectos clínicos e forma de tratamento. Maxi-Odonto, v.1, n.2, p.1-24, mar./abr. 1995.

68- POLHAGEN, L.; BRÄNNSTRÖM, M. The Liquid moviment in desiccated and rehydrated dentine in vitro. Acta Odont. Scand., v.29, n.1, p.95-102, Jan./Feb. 1971.

69- PRATI, C. What is the clinical relevance of in vitro dentine permeability tests?. J. Dent., v.22, n.2, p.83-8, Apr. 1994.

70- PRATI, C.; MONGIORGI, R.; FERRIERI, P. Effects of desensitizing toothpastes on dentine permeability. Archs. Oral Biol., v.39, p.144S, 1994. Supplement.

71- REEDER, O.W. et al. Dentin permeability: determinants of hydraulic condutance. J. dent. Res., v.57, n.2, p.187-93, Feb. 1978.

72- SASAZAKI, H. ; OKUDA, R. Periodic observation of the exudation from the dentinal tubules with time. Jap. J. Cons. Dent., v.37, n.6, p.1708-18, 1994.

73- SENA, F.J. Dentinal permeability in assessing therapeutic agents. Dent. clin. N. Amer., v.34, n.3, p.475-90, July 1990. 
74- SHONO, Y. et al. A new oxalate treatment for dentine tubule occlusion. Archs. Oral Biol., v.39, p.135S, 1994. Supplement.

75- SIMPSON, M.D. et al. Effects of aluminium oxalate/glycine pretreatment solutions on dentin permeability. Amer.J. Dent., v.5 , n.6, p.324-8, Dec. 1992.

76- STEVENSON, T.S. Fluid moviment in human dentine. Archs. Oral Biol., v.10, n.6, p.935-44, Nov./Dec. 1965.

77- SUGE, T. et al. Duration of dentinal tubule occlusion formed by calcium phosphate precipitation method: in vitro evaluation using synthetic saliva. J. dent. Res., v.74, n.10, p.1709-14, Oct. 1995.

78- THOMAS, H. F. The dentin-predentin complex and its permeability: anatomical overview. J. dent. Res., v.64, p.607-12, Apr. 1985. Special issue.

79- WICHGERS, T.G.; EMERT, R.L. Dentin hypersensitivity. Oral Health, v.87, n.3, p. 51-9, Mar. 1997. 
80- YAMAMOTO, H. et al. Precipitation of oxalates in dog dentinal tubules in vivo. In: INTERNATIONAL CONFERENCE ON DENTIN/PULP COMPLEX 1995; INTERNATIONAL MEETING ON CLINICAL TOPICS OF DENTIN/PULP COMPLEX. Chiba, 1995. Proceedings. Tokio, Quintessence, 1996. p.27879.

81- YOSHIYAMA, M.; SUGE, T.; EBISU,S. Morphological characterization of tubelike structures in hypersensitivite human radicular dentine. J. Dent., v.24, n.1/2, p.57-63, Jan./Feb. 1996.

82- YOSHIYAMA, M. et al. Scanning electron micoscopic characterization of sensitive vs. insensitive human radicular dentin. J. dent. Res., v.68, n.11, p.1498-502, Nov. 1989.

83- YOSHIYAMA, M. et al. Transmission electron microscopic characterization of hypersensitive human radicular dentin. J. dent. Res., v.69, n.6, p.1293-97, June 1990.

84- ZHANG, Y. et al. The effects of pain-free desensitizer on dentine permeability and tubule occlusion over time, in vitro. J. Clin. Periodontol., v.25, n.11, p.884-91, Nov. 1998. 


\section{ABSTRACT}

The influence of time after application of commercially available dentin desensitizing and experimental agents was assessed by using an in vitro method to measure dentin permeability by determinig the hydraulic conductance of dentin discs. Fifty dentin discs were cut from extracted human third molars and randomly divided into 5 groups of 10. In the group I OXA-GEL was used, in the group II experimental agent DD-1, in the group III experimental agent DD-2, in the group IV a placebo agent and in the group V, DEIONIZED WATER. In all groups the minimum and the maximum dentin permeability values were determined over simulated smear layer and complete smear layer removal by acid-etching, respectively. Following these baseline measuments, the agents were applied and hydraulic conductance of dentin was measured over the time intervals studied (immediate, 5, 15 e 30 minutes) after application. The last procedure was the determination if treatment was modified by submition of all specimens to an acid challenge. The results showed that the hydraulic conductance of dentin decreased with time for all groups. Groups I, II e III (OXA-GEL, DD-1 and DD-2) were not significantly different among themselves in all conditions, and groups IV e V (PLACEBO e DEIONIZED WATER) were not different as well. However, a statistically significant difference between OXA-GEL, DD-1 and DD-2 and PLACEBO and DEIONIZED WATER was detected. In respect to acid challenge, groups I, II and III treatments were acid resistant, however, in groups IV and $\mathrm{V}$ treatments were acid sensitive. The decrease of permeability with time observed in group $\mathrm{V}$, in which no dentin desensitizing agents was employed, 
indicates that the interpretation of the other groups results might be done with caution. 